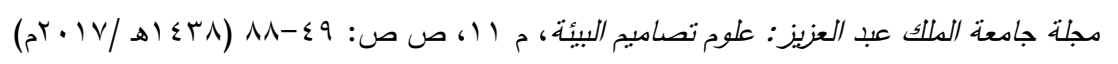

DOI: 10.4197 / Env.11-2

\title{
المسجد ذو الفناء الداخلي من التراث إلى المعاصرة: أدواره الوظيفية والبيئية والتتكيلية
}

\section{وائل حسين يوسف أحمد (')}

قسم عمارة البيئة، كلية تصاميم البيئة، جامعة الملك عبد العزيز، جدة، المدلكة العربية السعودية

hywael@hotmail.com

المستخلص. مثل الفناء داخل المسجد في عمارته الأولى أحد أهم العناصر الوظيفية والاجتماعية الأساسية بل والبيئية، وتكون المسجد في البداية من عنصرين؛ مساحة مغطاة ومساحة أخرى مكشوفة تمثل الفناء، والذي أحبط في أغلب المساجد بالأروقة من عدة جهات،

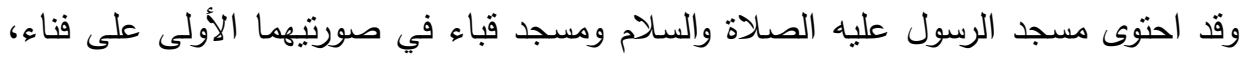

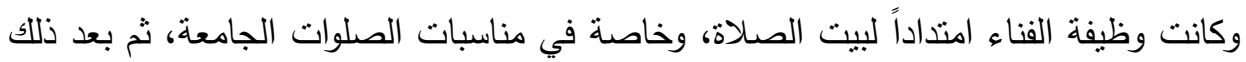

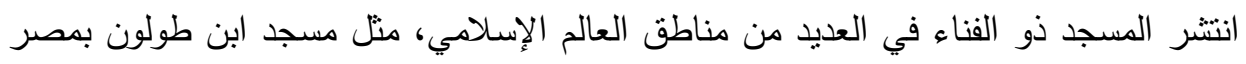

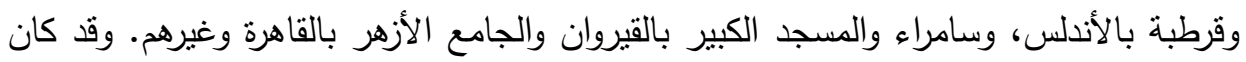

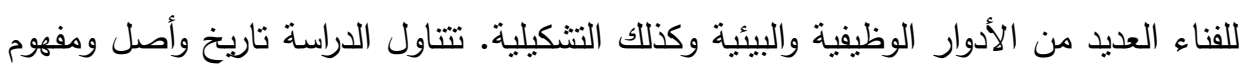

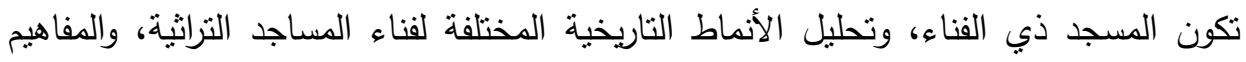
المؤثرة على تكوينه، وعلاقة الفناء بفراغات المسجد، مع نوضيح للمفردات التثكيلية لعمارة الفناء وأثرها على فراغ واستعمال الفناء، ثم تتعرض الدراسة للمستجدات التي طرأت على الفناء وأدت

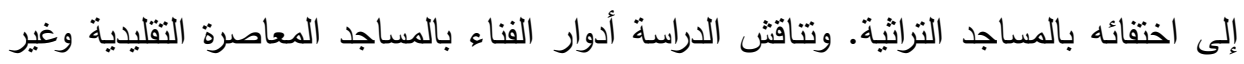
التقليدية، وتتنهي الدراسة بالعوامل التي أثرت على تكوين الفناء. كلمات مفتاحبة: المسجد، الفناء، الرواق، الصحن، المجاز. 
في الأحكام التي أوردها خاصة بسائر المساجد.

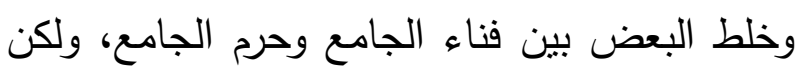

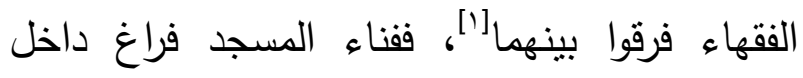
المسجد غبر مسقوف، وأما حرم المسجد فالمنطقة المحيطة به أو ملاصقة له أو رحبات خارجه، وقد تمنت الصلاة إليها في أيام الجمع والأعياد إذا ازدحم

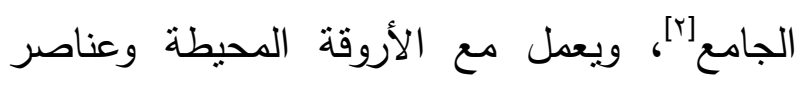
المسجد الأخرى منظومة مناخية من الظلال وحركة وليعة الهواء وتوفير الإضاءة غير المباشرة لفراغات المسجد. وفي المساجد التراثية تم تحديد نواجد الفناء وشكله ومساحته تبعا للظروف المناخية بالمكان، فنجد أن مساحتها تصغر كلما اتجهنا شمالا أو جنوبا باليا

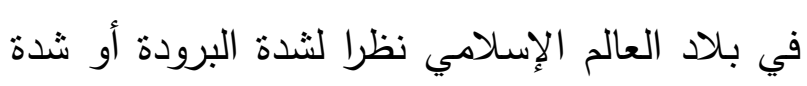

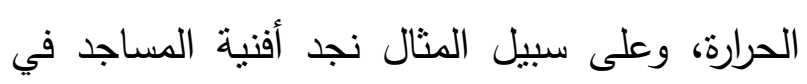
المنطقة العربية وإيران والهند كبيرة المساحة، بينما تصغر مساحتها في آسيا الصغرى وما وراء النهر وتهري وتركيا][] تصني

\section{1- أصل تكون الفناء بالمساجد}

يعود المفهوم الأول لتكون الفناء بالمساجد

لمسجد الرسول صلى الله عليه وسلم في المدينة المنورة، ثم استمر في عهر الخلفاء الراشدين، (ثكل r)، وكان يتكون من جزء مسقوف بالجهة الثمالية،

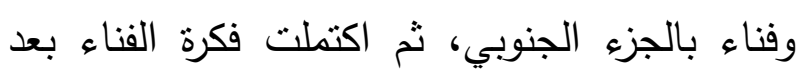
تحويل القبلة من الثمال إلى الجنوب، وتم إنثاء

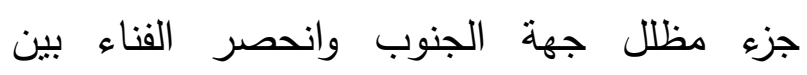

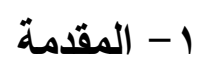

إثنكالية الدراسة: ندرة الفناء في غالبية المساجد المعاصرة، ومدى تحقيقه لأدواره الأساسية. هدف الاراسة: دراسة واستلهام القيم والمفاهيم لفناء المساجد التراثية، وتحليل دور الفناء وتقييمه بالمساجد المعاصرة بهدف الوصول إلى خلاصة

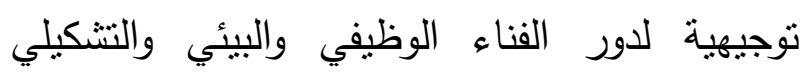
بالمساجد.

منهج الدراسة: انتهجت الدراسة المنهج الوصفي التحليلي، من خلال تحليل النماذج التراثية

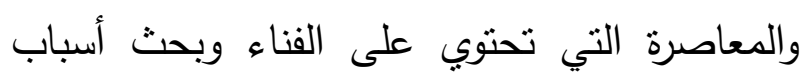
تراجعه في بعض الأماكن. ويوضح شكل ( معايير

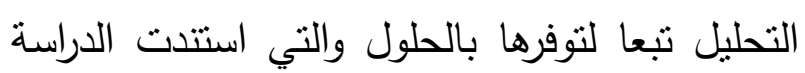
فيها على تقييم الفناء ودوره وهدفه.

r. تاريخ وأصل ومفهوم تكون الفناء بالمسجد

\section{1 - 1 تعريف فناء المسجل}

الفناء هو الجزء غير المسقوف داخل المسجد.

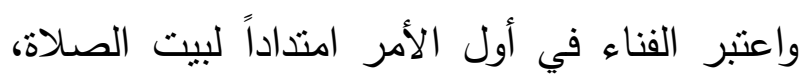

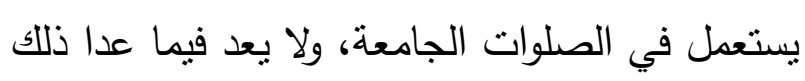

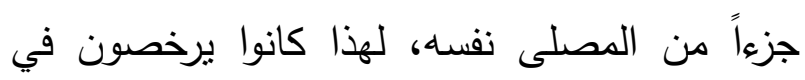

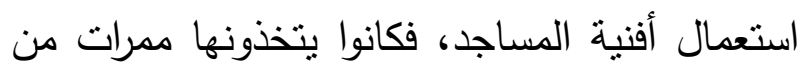
طريق إلى آخر، وربما في بعض الأنشطة الأخرى كالبيع أو الثراء أو النوم، ثم أخذ الفقهاء يحددون كيفية استعمال أفنية المساجد، وقد بين ذلك الزركثي التي 
مكانا مخصصا لذكر الله وعبادته وهي الأساس الذي يحول بموجبه الحيز المكاني من شيء دنيوي إلى الى شيء ديني][ـ. وقد تجسدت الناحية الوظيفية للفناء في مدى كفايته لمنطلبات الصلاة والاجتماعات ومناقنة أمور المسلمين، ومناسبة موضعها بالنسبة لمنية

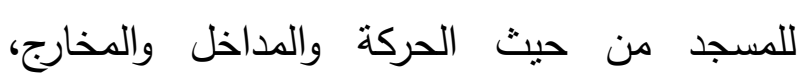
والتوجيه ناحية القبلة، منوافقا مع البيئة باستعمال مواد بناء بسيطة ومنتفرة، محاطاً بفراغات مسقوفة لتوفير الظله، معبرا ببساطة عن وظيفته الأساسية،

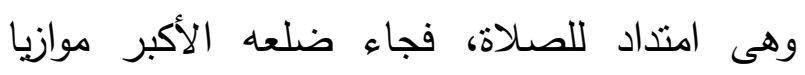

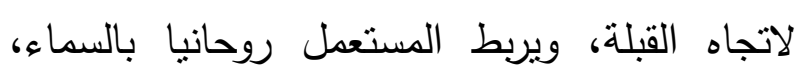

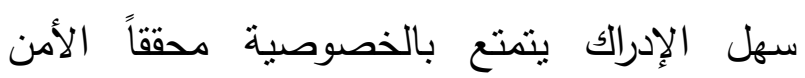
والأمان.

\section{r. المفاهيم التصميمية لفناء المسجد بالعملان التراثي}

تتتاول الدراسة في هذا الجزء المفاهيم التصميمية للفناء بالعمران التراثي بعصوره المختلقة

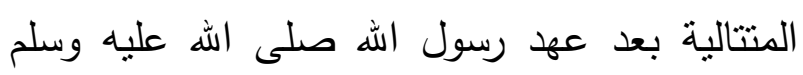

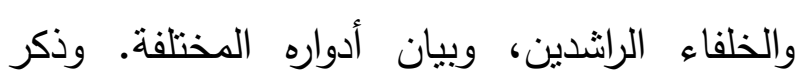
مارتن فريشمان أن "التطور المبكر للمسجد كان مبنياً

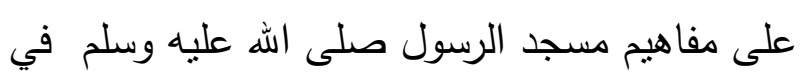
المدينة، حيث اصطفت أماكن سكنه على جانب من هن المبله

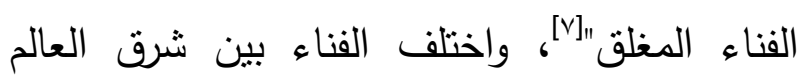
الإسلامي وغربه. فحين حافظ الفناء على صغر مساحته في مساجد المغرب الإسلامي، كبرت مساحته في مساجد المشرق، واحتل مؤخرة الظلة
السقيفتين، وأصبح للفناء دوراً أساسياً، حيث يتم اللجوء إليه لأداء الصلاة في الليالي الحارة. واحتوى

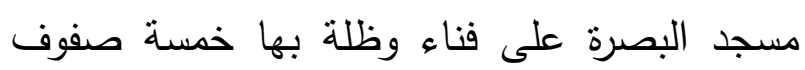

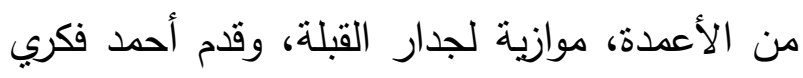
رسماً تبين منه وجود فناء كبير في الوسط، تحيط به الاعدار

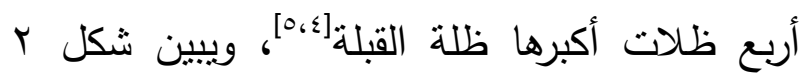
تواجد الفناء بمساجد حقبة الرسول صلى الله عليه وسلم والخلفاء الراشدون.

يعد المفهوم الأساسي للفناء في عهر رسول الله صلى الله عليه وسلم والخلفاء الراشدين هو مفهوم وظيفي روحاني اجتماعي، فكانت تقام به الأنشطة

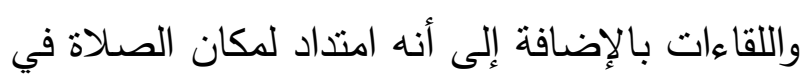

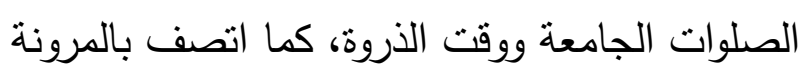
من حيث المساحة والاستيعاب وسعة المصليين، وبساطة التشكيل وموضع الفناء أدى إلى سهولة علاقات الحركة منه وإليه، وكان لاستعمال مواد التهاه البناء البسيطة المحلية عاملاً مهماً في الأبعاد المعنوية والبيئية. يوضح شكل r مفاهيم تكون الفناء المادية والمعنوية وأبعاد التكوين والتشكيل في تلكي الفترة المهمة. وقد وصف عبد الواحد الوكيل هذا ولئ ولئ النوع الذى نراه في المساجد التي بنيت في فترة إسلامية مبكرة، ويمكن تصوره بتحديد قطعة أرض فئ لتراه عن طريق إقامة سور يحيط بها وإقامة منطقة مظللة على طور جدار القبلة المشيدة باتجاه مكة المكرمة. هذه الالتفاتة المتمنكة بتحديد الحيز المكاني وجعله 
الأكبر للصفوف الأولى، وعمل الخروج التدريجي للضوء إلى هذه المساحة المفتوحة للسماء قيمة روحانية والثعور بالسمو والاتصال الرمزي بالفراغ الفاه الأعظم والسماء.

r r r r المفا هيم التصديمية لفناء المسجد في العصر العباسسي

نظراً لأن الدولة العباسية انصرفت في بداية

عهدها إلى مطاردة خصومها من العلويين والأموبين.

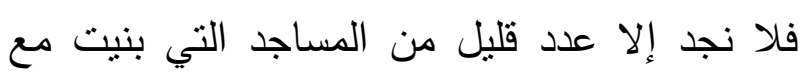

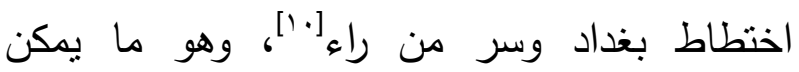

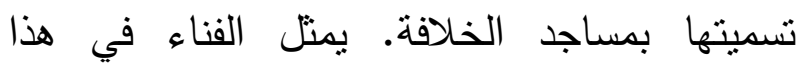

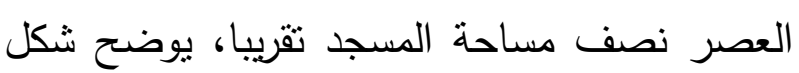
7 أثشر المساجد في ثلأك الفنرة.

حافظ الفناء في تلاك الفترة على بساطته واندماجه مع المسجد في المفهوم التتكيلي ووحدة

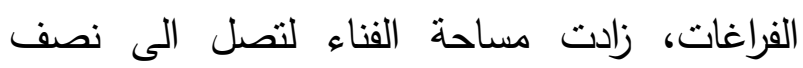
المساحة الكلية للمسجد استجابة للحاجة إلى فراغ كبير للقاءات والاجتماعات والمشورة، وشكل فراغ الفناء مقياس تذكاري يزيد من الثعور الروحاني بالسمو بشكل أكبر مما سبق، ونظرا لبساطة عناصر المسجد لئد

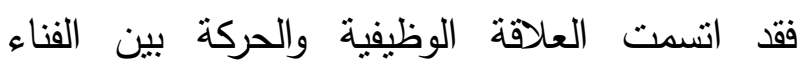
وفراغات المسجد بالقوة والسهولة، التصميم البسيط لوفيك لفراغ الفناء سهل إدراكه وقراءته بسهولة، بالإضافة لقوة تشكيله بالأروقة المحيطة التي زادت من خصوصيته، خالفت بعض المساجد توجيه الضلع الأكبر للفناء
المخصصة للصلاة؛ والمسقوفة بالقباب الكبيرة

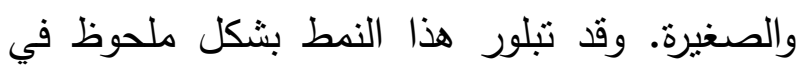
المساجد العثمانية. مع استمرار هدفه ودوره الوظيفي والاجتماعي مع بعض المتغيرات القليلة في دوره

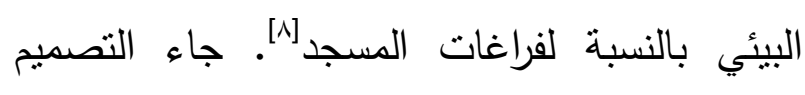
بسيطا واستجابة مباشرة لاحتياجات المجتمع، والتأكيد على التوحيد في الإسلام، حيث العلاقة بين الخالق والمخلوق [9].

r - 1 المفا هيم التصديمبة لفناء المسجد في العصر

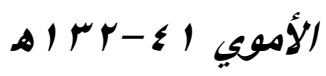

تطورت مفاهيم ومفردات فناء المسجد الجامع في العصر الأموي، نظراً لأن كثيراً من الفاتحين استقروا في مدن الثشام والعراق ومصر ، وبلاد الثمال الإقريقي، حيث كانوا يستخدمون أساليب منطورة في

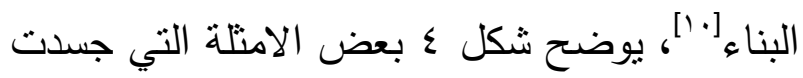
غالبية المفاهيم في تلك الفترة.

نظرا لثبات المرجعية والثوابت الفكرية

والاجتماعية وتقارب البيئات، فقد حافظ الفناء على لبى

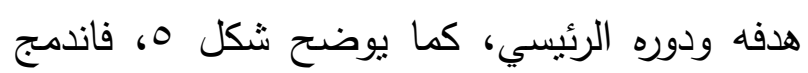

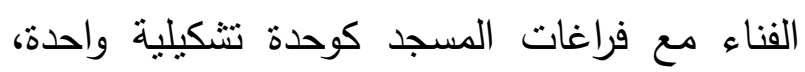
ومنل أيضاً امتداد لفراغات المسجد الداخلية، وخضع للمعايير التصميمية في علاقته الوظيفية وسهولة الحركة والاتصال بالعناصر المحيطة، بسيط النتكيل

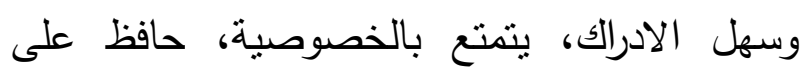

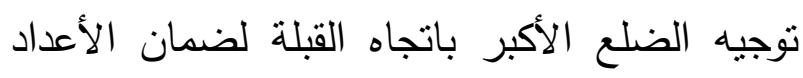


المتعامــدة التـي تعهـل كـدليل تـوجيهي للأيوانـات المخصصــة للمـذاهب، قلـت خصوصـيته الوظيفيـة

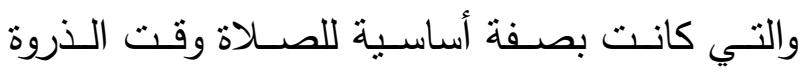

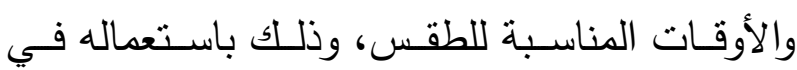
الحركة والتنقل بين الإيوانات، وزاد احتوائه الفراغي بهي والهي

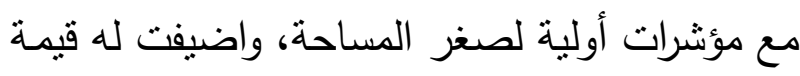

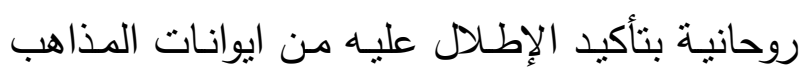

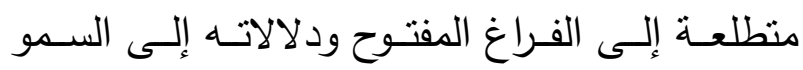
الروحاني، ويوضح شكل 9 موجهات ومفاهيم تصميم الفناء في نلك الفنرة.

تشــابهت الأفنيـة فـي مسـاجد مغـرب العـالم

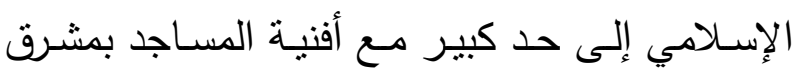

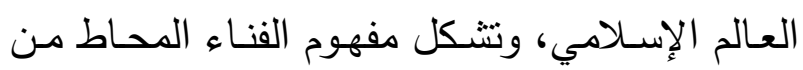

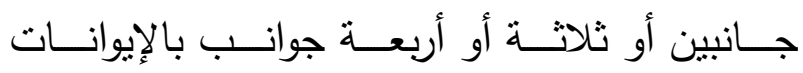

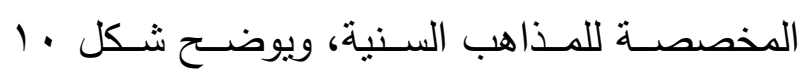
بعض الأمتلة المهمة في مغرب العالم الإسلامي.

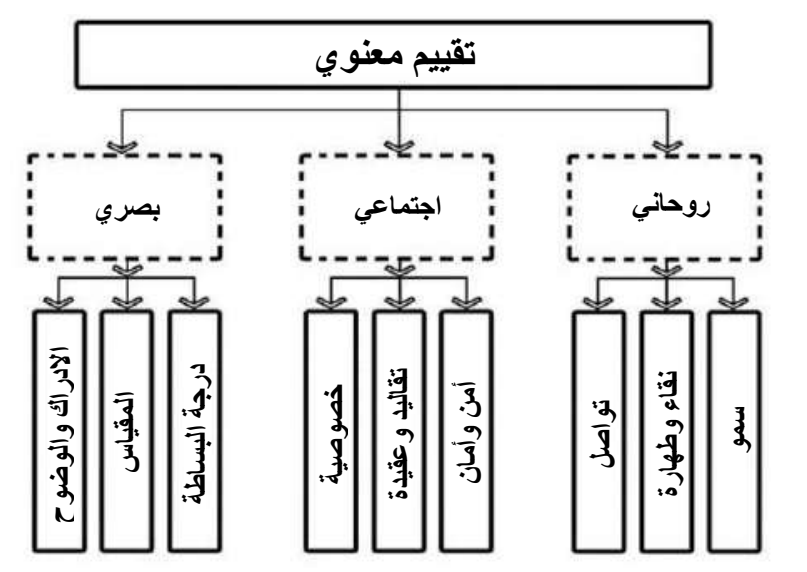

لاتجاه القبلة، كما هو معتاد بمعيار زيادة عدد

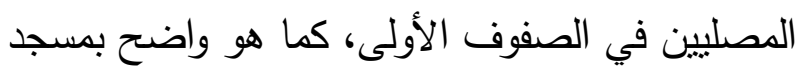
سامراء. ويوضح شكل V V المفاهيم التصميمية والتتكيلية للفناء في العصر العباسي. r - r المفاهيم التصديمية لفناء المسجب للاويلات

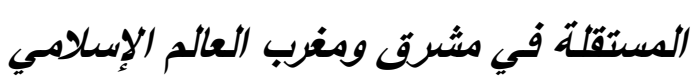

تهنم الدراسة بتحليل مفاهيم تصميم الفناء ودوره في تلك الدويلات، ويوضح شكل ^ م أمنلة لمساجد الدويلات بمشرق العالم الإسلامي. أدى وجود عناصر مستحدثة كالايوانات التي تحبط بالفناء، والتأكيد على المجاز ببعض المساجد والتي سبق تواجدها بالمساجد الامويـة، إلى التأثير

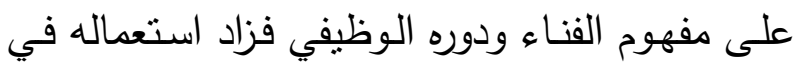
الحركـة بين فراغـات المسـد، وظل تشكيل الفنـاء على بساطته وسهولة إدراكه مع وجود نقاط توجيهية متعـددة للفراغـات، ومؤكــا علـى تميـز المحساور

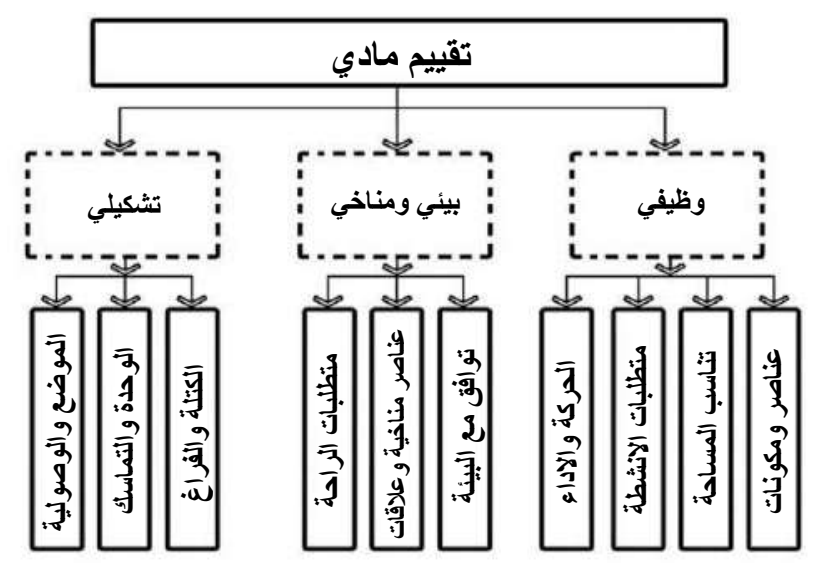

شكل اـ منهجية وعناصر تقييم الفناء (الباحث). 


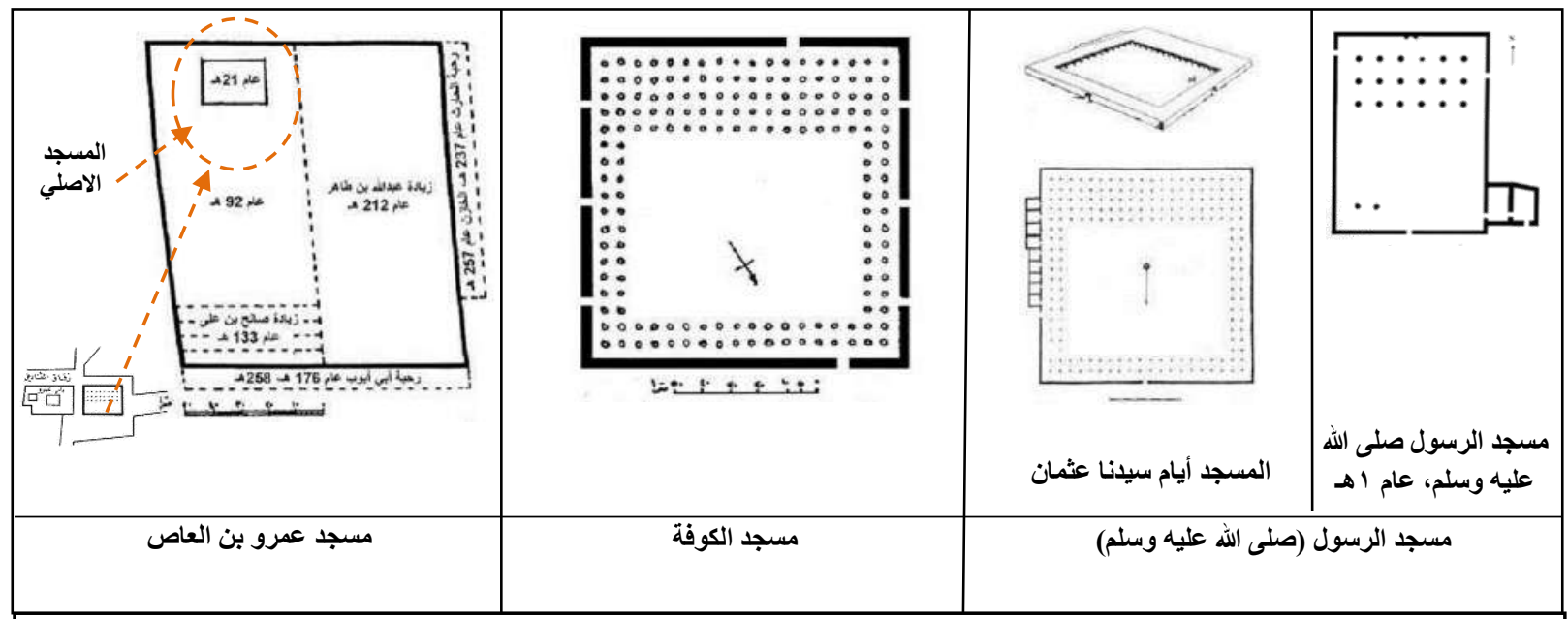

الفناء في المساجد الجامعة في عهد الرسول وعهد الخلفاء الراثندين له دوره الاجتماعي والوظيفي والبيئي المهم، كمجد قباء ومسجد بني

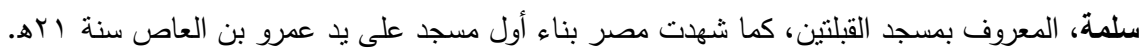

شكل Y. فناء المسجد في صورته الأولية بالمساجد الجامعة في عهد الرسول والخلفاء الراشدين [؛، با -0 1].

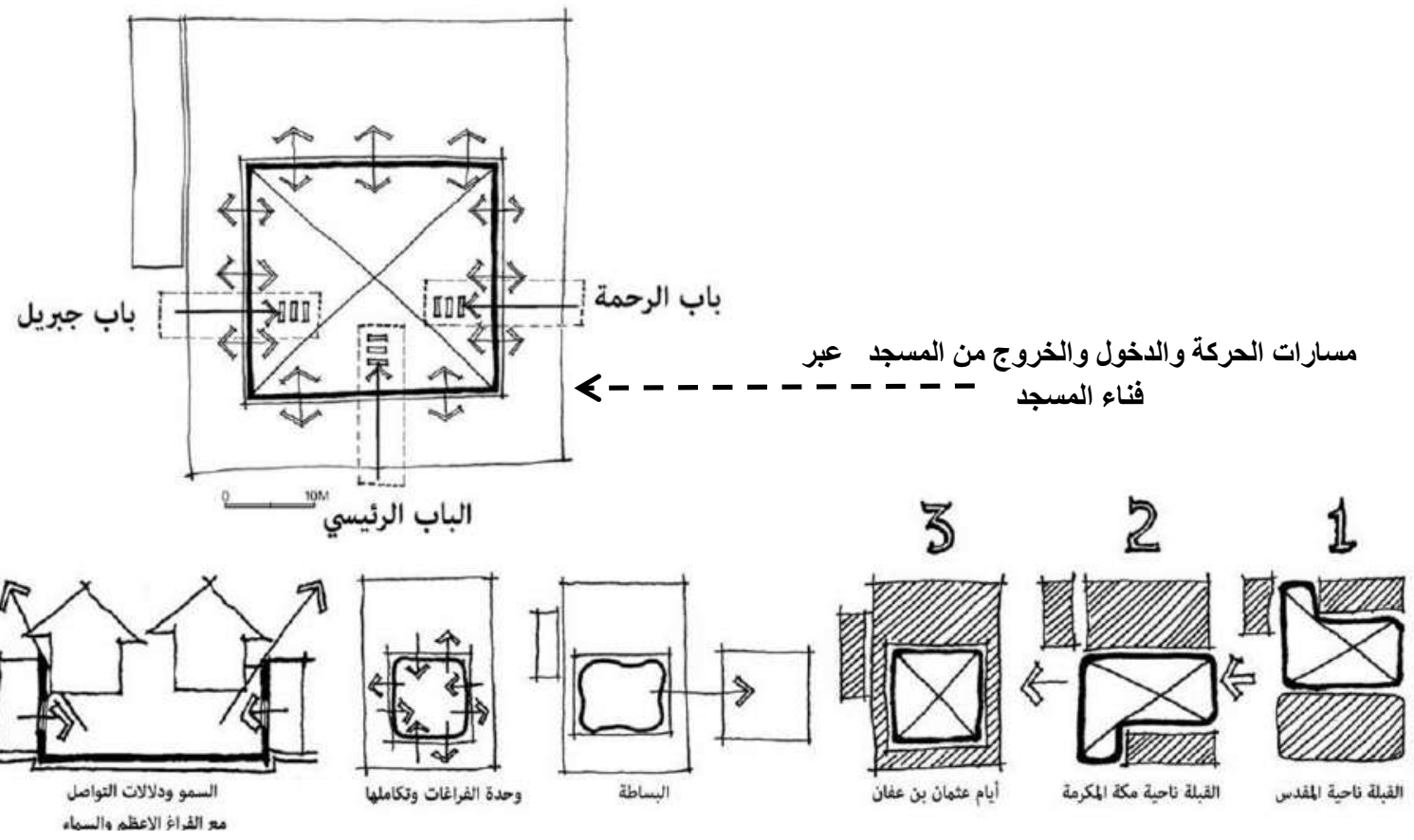

شكل بـ. مفاهيم تكوين فناء مسجد الرسول صلى الله عليه وسلم المادية والمعنوية في عهد الرسول والخلفاء الراشدين (الباحث). 


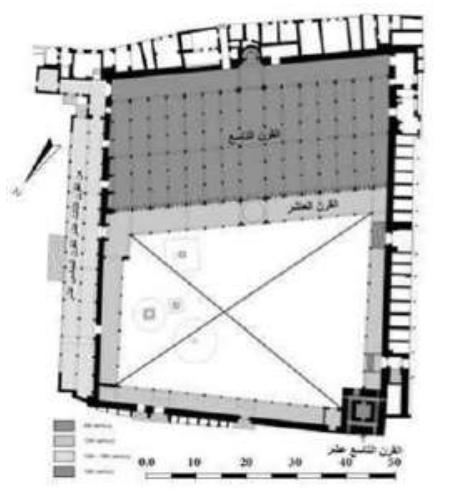

مسجد الزيتونة بتونس، مساحة المسجد:

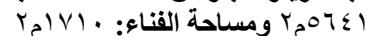

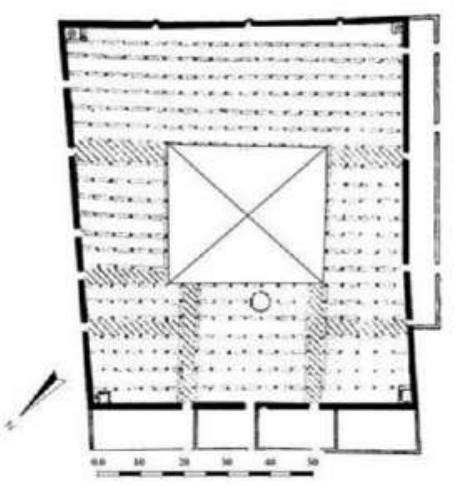

مسجد عمرو بن العاص بالفسطاط، مساحة

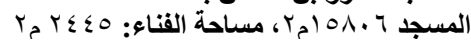

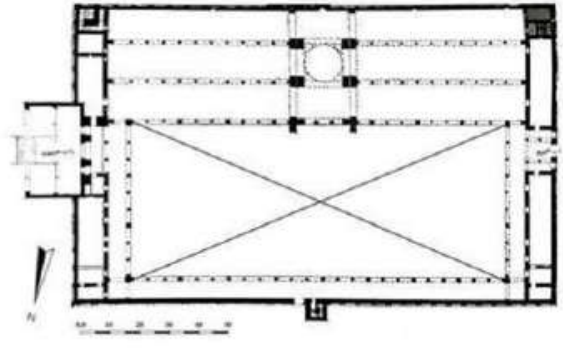

الجامع الأموي في دمثق، مساحة المسجد

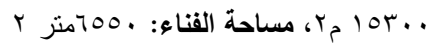

شكل \&. أمثلة للمساجد المهمة في العصر الأموي [9،؛]

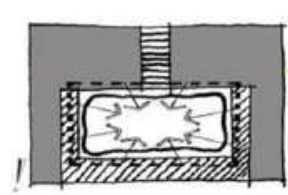

琽

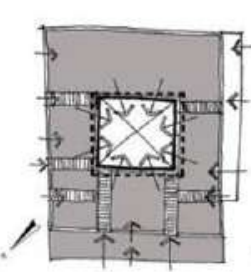

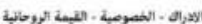

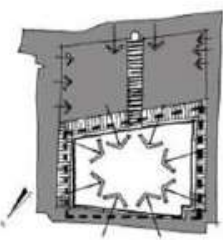

الادراث - الطصومبة - القيمة الروحانية

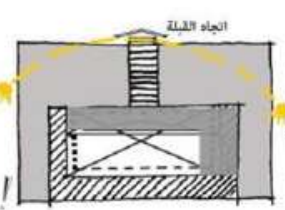

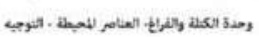

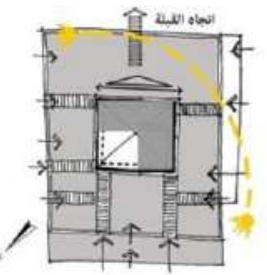

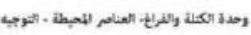

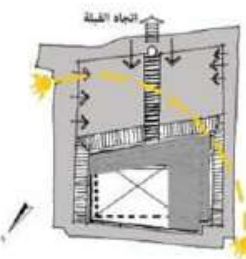

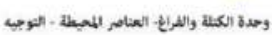
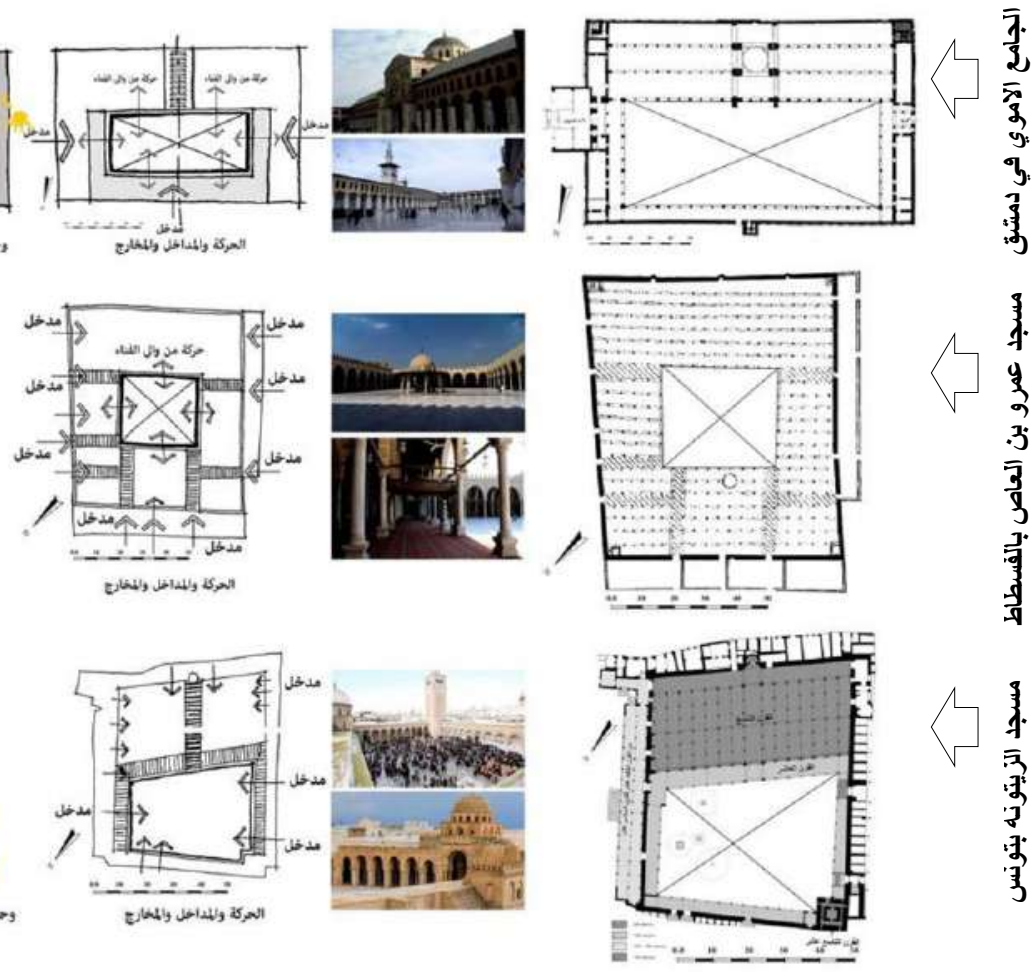

شكل ه. المفاهيم التصميمية للفناء بالمساجد المختارة للعصر الأموي (الباحث). 


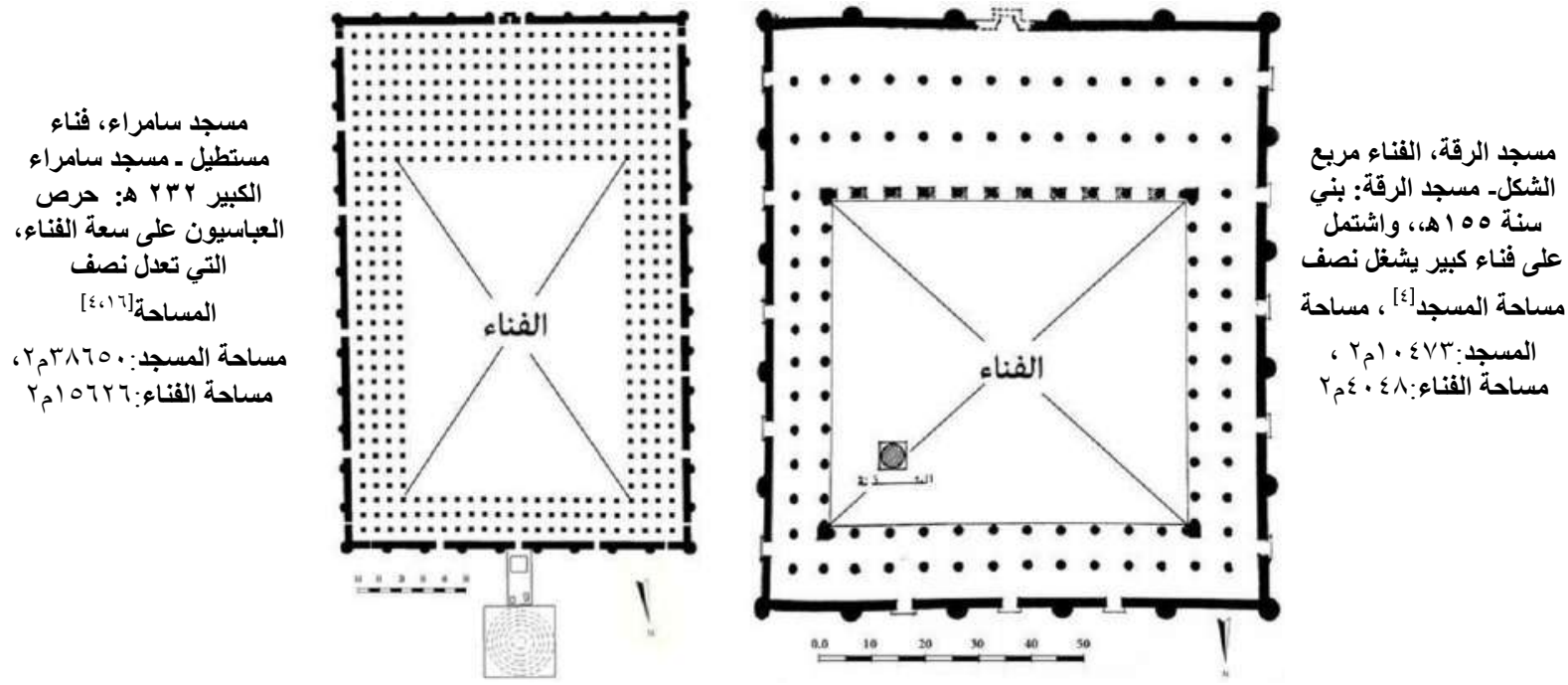

شكل 7. أمثلة للمساجد المهمة في العصر العباسي الأول.
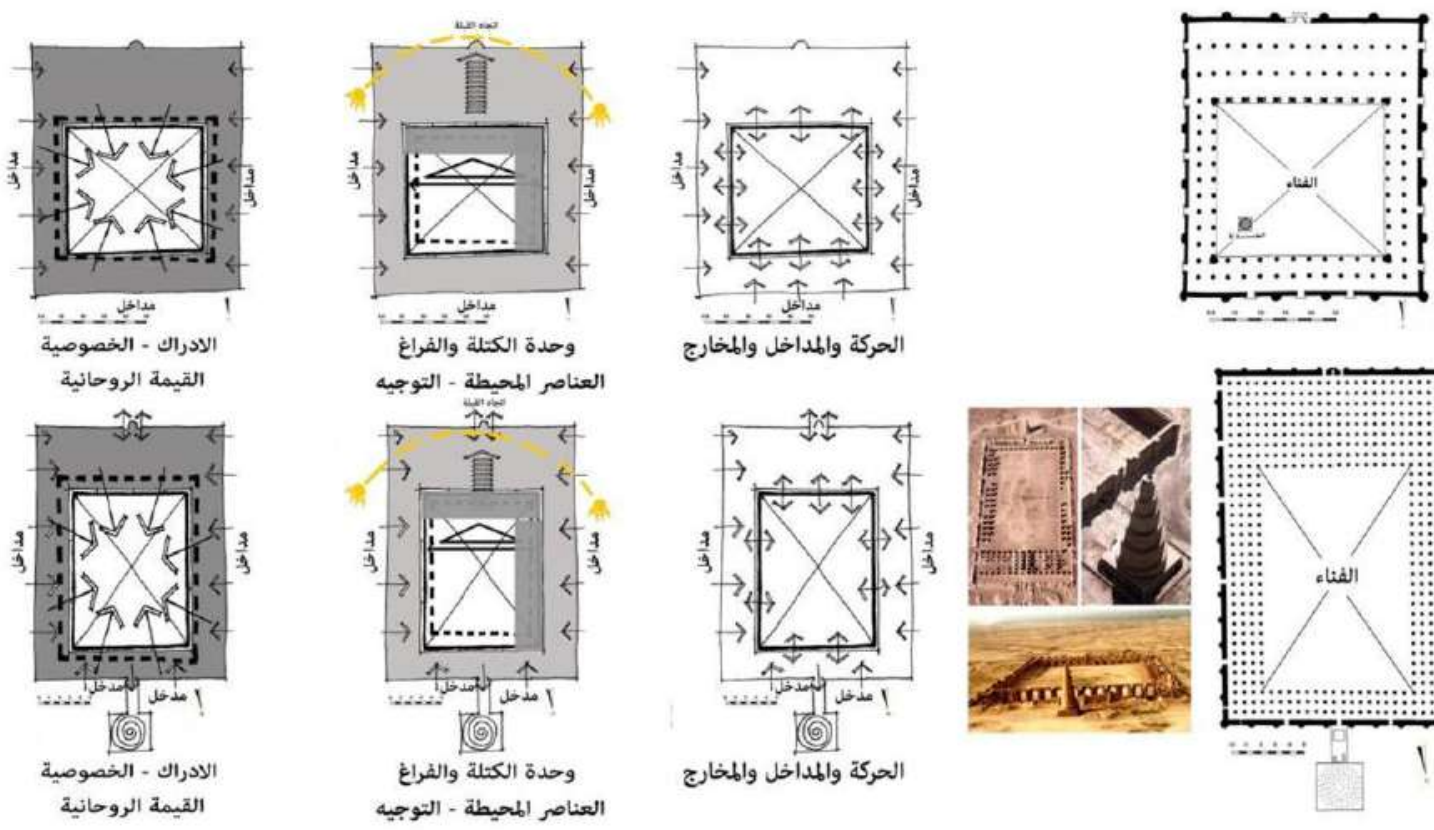

年
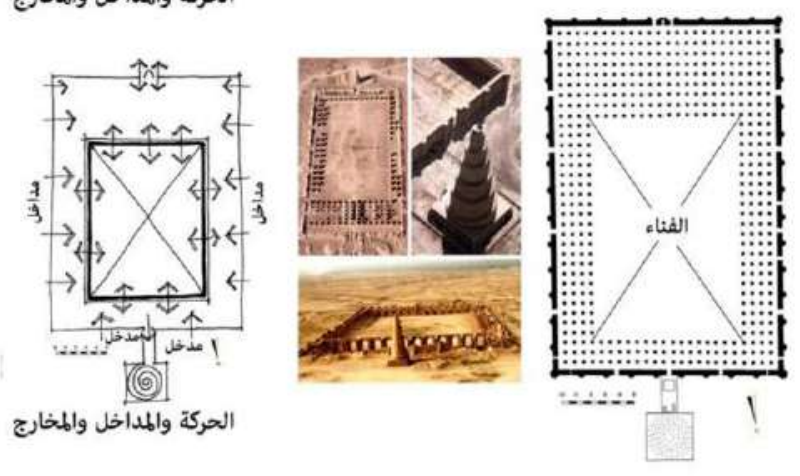

$\frac{3}{7}$
$\frac{3}{4}$

شكل V. المفاهيم التصميمية للفناء بالمساجد المختارة للعصر العباسي (الباحث). 

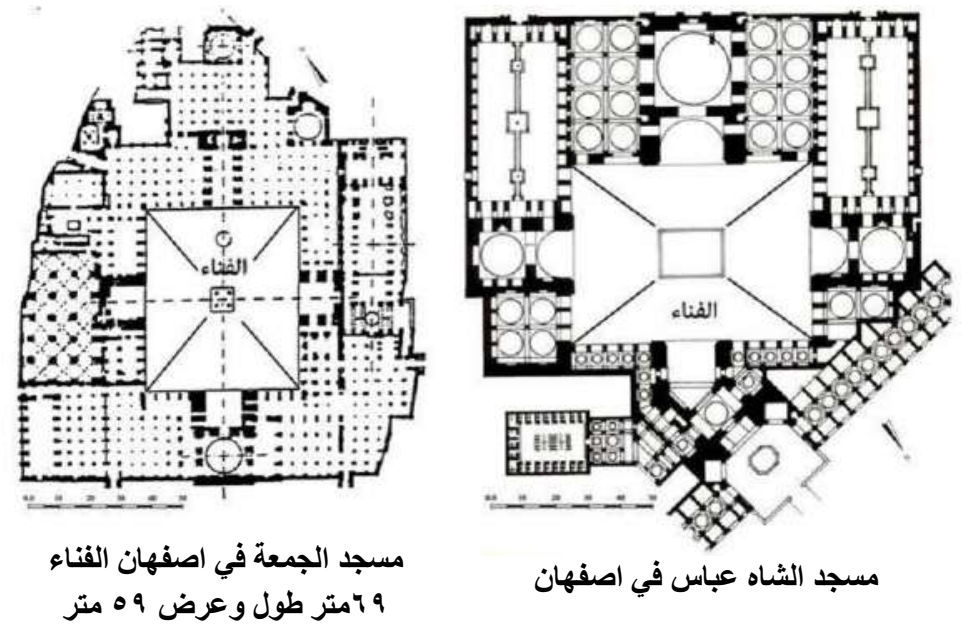

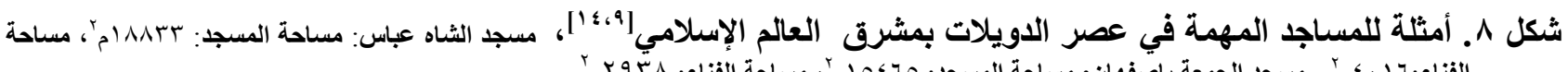

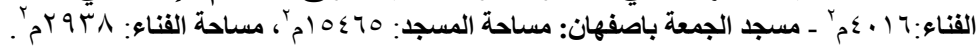
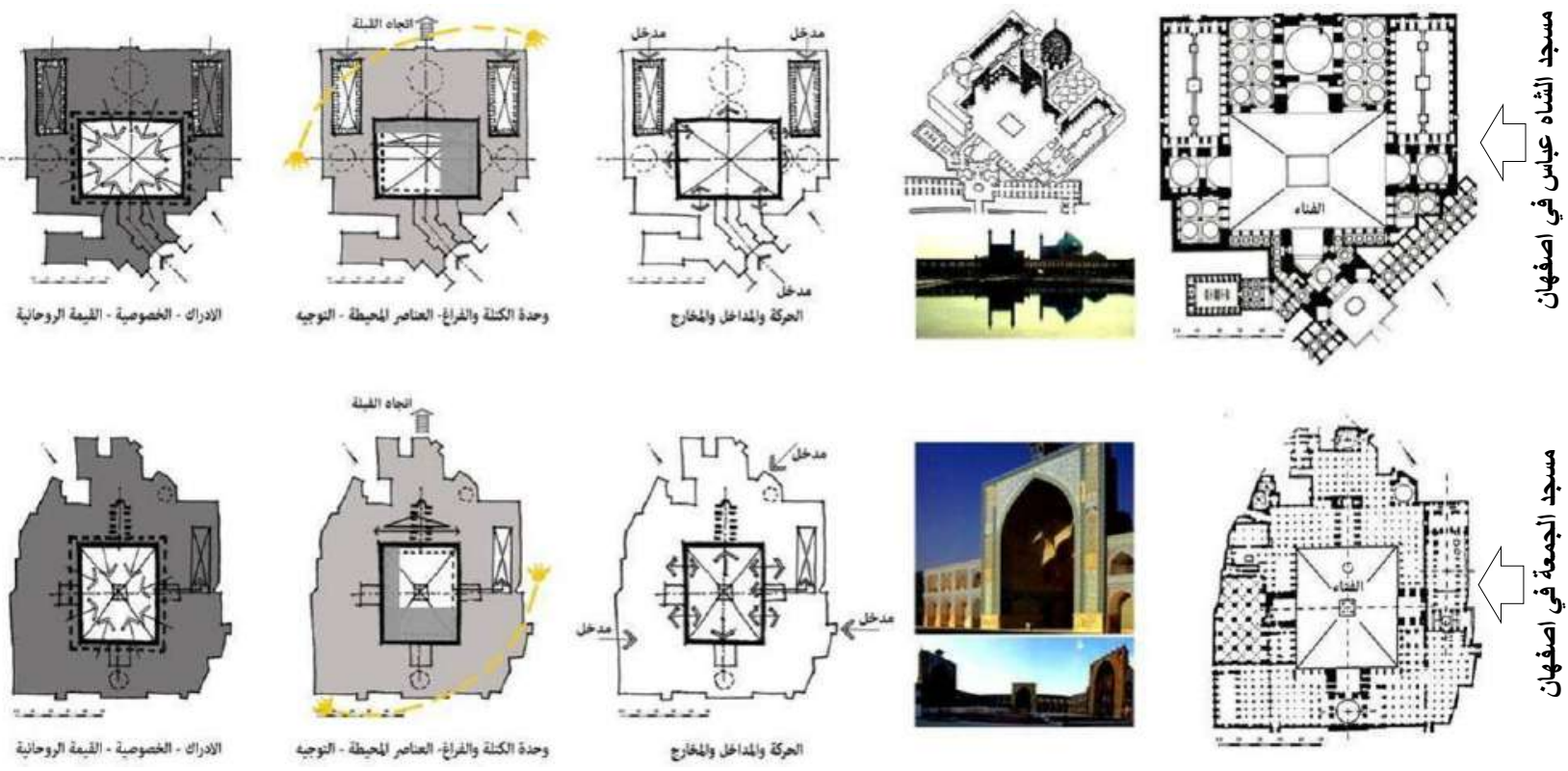

شكل 9. المفاهيم التصميمية للفناء بمساجد عصر الدويلات بمشرق العالم الإسلامي (الباحث). 

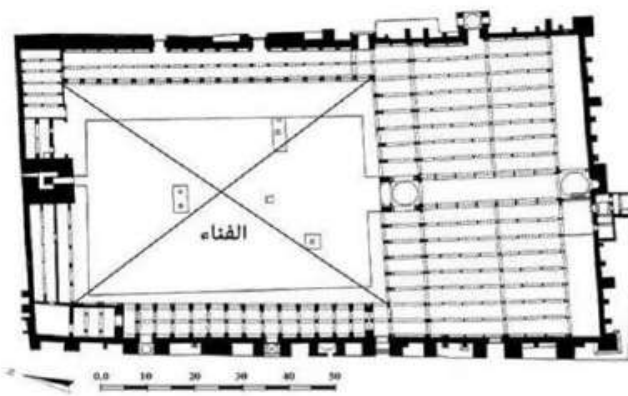

مسجد القيروان - تونس
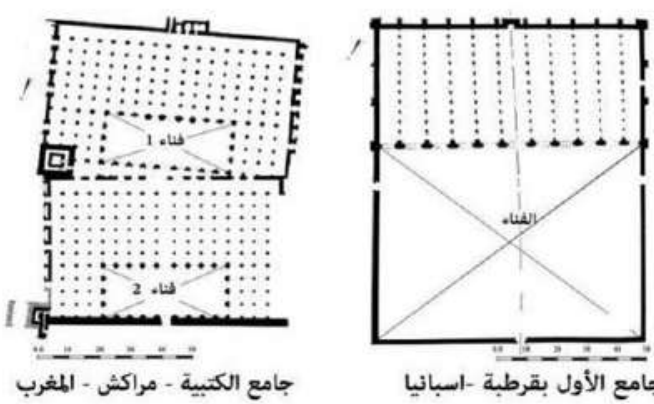

الجامع الأول بقرطبة -اسبانيا
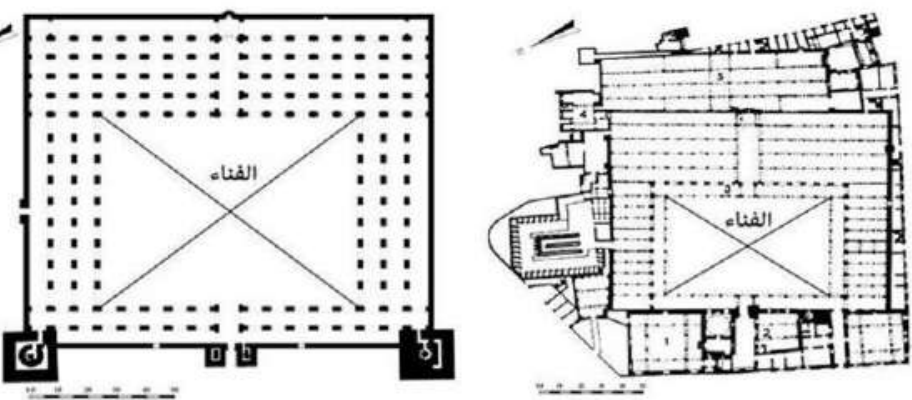

مسجد الحاكم - القاهرة

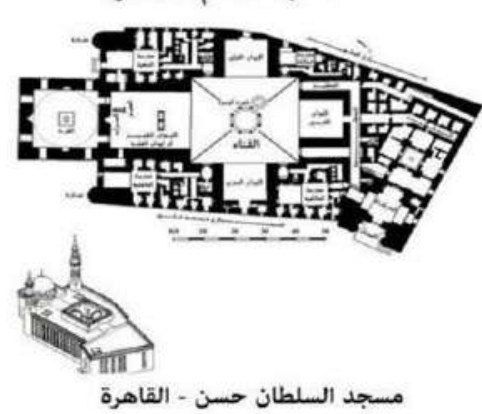

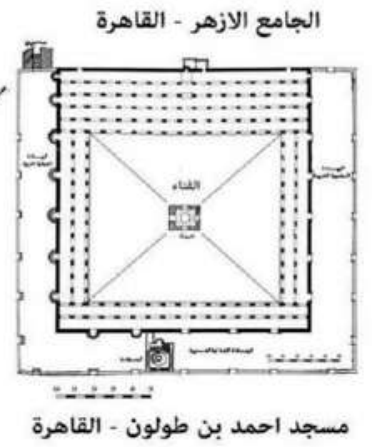

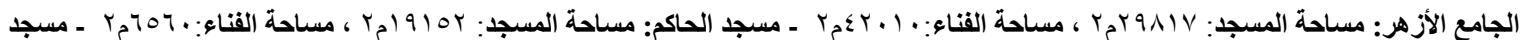

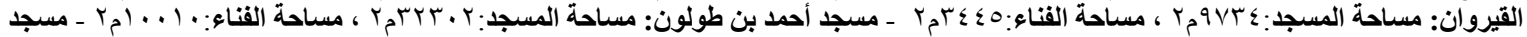

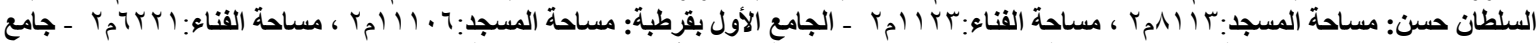

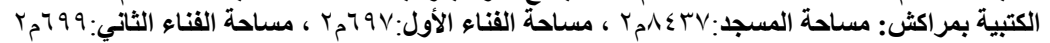

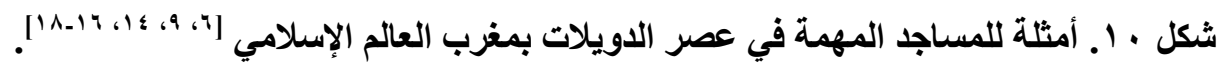

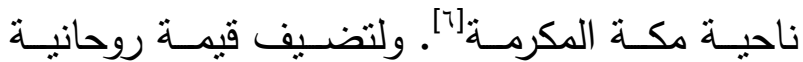
لقيمتها المادية. ولم يثبت نسبة واضحة بين مساحة المسجد والفناء فقد تراوحت بين V, • مثنا في الجامع

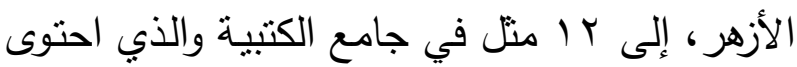
على فنائين متقاربين في المساحة، ويعود ذلك للعديد من العوامل، منها المراحل التي مر بها بناء المسجد

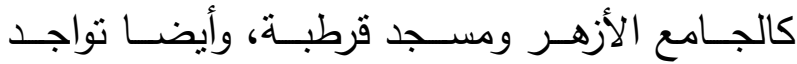
الإيوانات ببعض المساجد والتي استحوذت على حيز

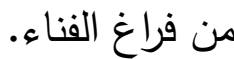

تم الحفاظ على الكثير من الثوابت الأساسية في مفاهيم تكوين الفناء، فاستمرت بساطة التكوين وادراكه، وظلت المرجعية الوظيفية المقترنـة بالتعاليم

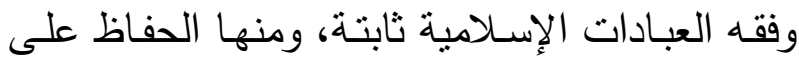

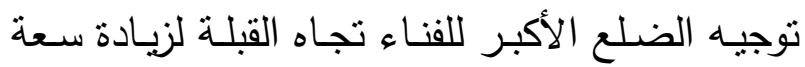
الصفوف الأولى، وذللك في غالبية مساجد تلاك الفترة، وزاد مـن الإحسـاس بالتوجيـه المعنوي والمـادي تلك لك الأروقة المتكررة والمرتكزة على الأعمدة على جانبي بالني

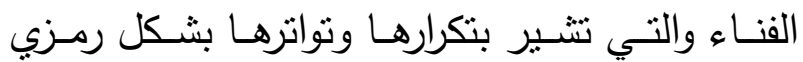


يعتبر خروج الفناء خارج كتلة المسجد من أهم

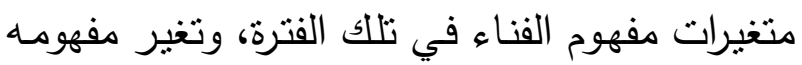
التصـيمي ليصـبح سـاحة خارجيـة بـدلا مـن فنـاء، واكتفي بدور وظيفي حيث يمثل امتدادا للصـلاة في

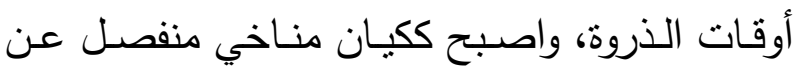

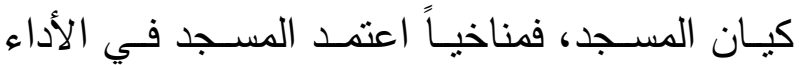
المنـاخي على التوجيه والفتحـات والتصـيم الفراغي

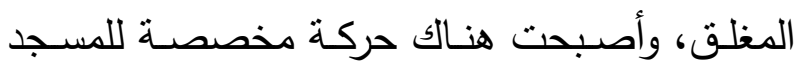
واخرى للفناء بجانب الاتصـال بينهــا، وفقد الفناء جزءاً من مفهومه المناخي بخروجه وإحاطته بأروقة لا تكـافئ منظومــة الفراغـات ذات العــق الــؤثر لتفعيل المنظومة الحرارية بين الفناء وفراغات المسجد وخارجه.

روحانيـا انفـلت استمرارية الثـعور المتـدرج الإضــاءة والطقس والارتفــاع بـين صـالة الصــلاة والفناء، وذلك للخروج المفاجئ من الصالات المغطاة بالقباب الأقل إضـاءة بشكل واضـح إلى فراغ الفناء المفاجئ والمختلف في الإحساس الفراغي والإضـاءة والطقس، فققد الإحساس بالسمو المصـاحب للتدرج

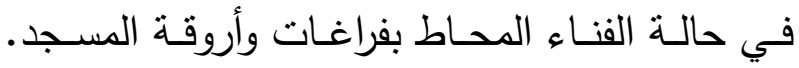
ويوضــح شـكل با اســتخراج المفــاهيم الموجهــة لتصميم الفناء في تلك الفترة.

بعد استخلاص المفاهيم التي أثرت على الفناء مـن خـلال موضـعه وعلاقتـه بالمسـجد والاعتبـارات

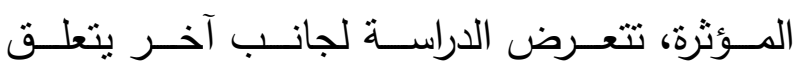

وجسدت مفاهيم المساجد في تلك الفترة وحدة التشـكيل، الـذى يعـود للبرنـامج الـوظيفي للمكونـات ومحورهم صالة الصلاة الرئيسية والفناء حيث يمثلان تكـوين مترابط ومتماســك، وضـبط العلاقـة الحركيـة الماديـة والمعنويـة بينهم، وقد عبر المفكر الفرنسـي "روجيـه جـارودي" عن تلكـ الوحدة في قولـه، "أنـا شخصيا حينما أرى روائع الفن الإسـامي اشعر بأن

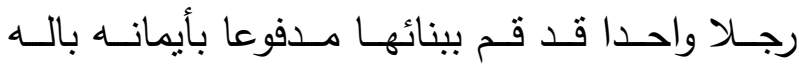
واحد"[9] ]ـ وقد اثر المناخ العام في المفاهيم المؤثرة والمحددة لفكرة الفنـاء وتكوين منـاخ مصنغر مثنالي داخـل المسـجد والمحـاط بقدر كـافٍ مـن عـروض للفراغـات في غالبيـة المسـاجد التي تحقق التفاعل المنــاخي وتــوازن المنظومــة الحراريــة بـين الفنــاء والمسجد والخارج. ويوضـح شكل ل/ 1 تحليل لمفاهيم التكوين والتشـكيل للمسـاجد المختـارة لمغـرب العـالم الإسلامي.

r - أ المفا هيم التصديمبة لفناء المسجد في العصر العثمانسي

ورث العثـــنيون سـلاجقة الــروم فـي آسـيا الصغرى، وساروا على نهجهم في العمارة والفنون [r] ويتمنل تخطيط المسجد العثماني في آسيا الصغرى، في قاعة صلاة مغطاة بقبة وفي مؤخرتها فناء واسع، تحبط بـه الأروفة المسقوفة غالبـا من ثلاثة جهة جهات

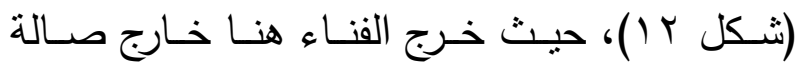

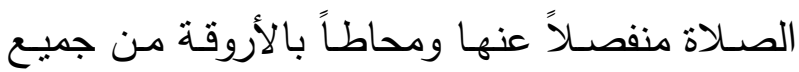

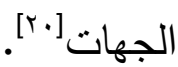


الأعمـدة والتيجـان والقواعد بالإضـافة إلى الأقواس

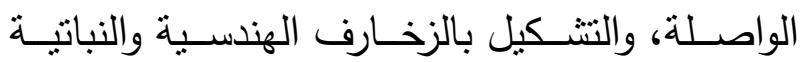
والآيـات القرآنيـة. وفي حـالات عـدم إحاطـة الفنـاء بالأروقـة مـن كـل الجوانـب، فـإن الجوانـب الأخـرى يحــدها فراغــات المســـد، وتعــالج هــذه الجــدران بالمفردات التشكيلية والحليات والفتحات ذات الطابع الخاص لكل منطقة، وفي حالات المساجد التي بها الإيوانـات كمسـد ومدرسـة السـطان حسن بالقاهرة، فـإن جدران الفنـاء تحتوي على واجهـات الإيوانـات الأربعـة، والتي تعـالج بالتشـكيلات والمفردات التي توجــه الدارســين بشـكل واضــح لتعدـل كمــداخل وموجهات حركة لهذه الإيوانات.

وفي كثير من المساجد يتم الدخول من خلال الأروقة المطلة على الفناء، ويأخذ الجزء المخصص للاخول عناصـر معماريـة تميزه، مثنل الممرات التي تبدأ من الفناء وتتتهي بالمحراب، وتسمى المجاز كما في المسجد الأموي بدمشق، وتأخذ طابعا خاصا في تشـكيل مفرداتهـا لكـي تتميـز عـن بـاقي عناصـر الـرواق، ويمثل عنصـر حركـة تـوجيهي للمسـتعمل، وفي غالبية الأفنية يوجد بالمنتصف عنصر معماري وتشكيلي ووظيفي مهم وهو الميضـأة، والتي تعددت أثنكالها واختلفت من عصر إلى عصر . في دراسـة عُرضـت "بالاقتصـادية أفادت بأنـه" "في أحد المسـاجد في محافظـة الأحسـاء بنـي قبـل أكثر من . . سنة، وحينما أُعيد بناؤه قبل أكثر من

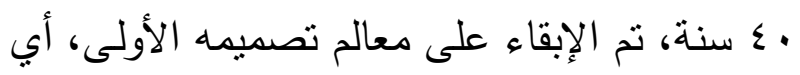

بـالمفردات المعماريـة التي تؤثز بشكل مباشـر وغير مباشر على كينونة ومفهوم الفناء بالمساجد التراثية.

\section{بـ المفردات المعمارية بأفنية المساجد التراثية وأثرها على فراغ واستعمال القناء}

اختلفـت العناصـر المكونـة للفنـاء بالمســاجد التراثبـة تبعـا لـنمط الفتـاء نفسـه، وتوضـح الأثـكال ع IV بعض العناصر والمفردات التي استعملت بعمارة الأفنيـة وتأثيرهـا الوظيفي والبيئي والتشكيلي. وبمثتل الـرواق في أغلـب الأفنبـة المفـرد الرئيسـي

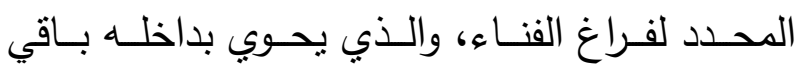

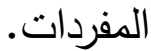

تساعد عناصر ومفردات أفنية المساجد لما لها من معاني وتشكيلات ذات مدلول رمزي على إدراك المستعمل لفراغ الفناء بعناصره ومكوناته وتدفعه على إدراك الكليـات ودراسـة تمايزهـا الجزئيـة داخل الكلـ، والنظــر إلـى المجـال الإدراكي ومــا يتضـــــهـ مـن عناصـر كوحدة واحدة، وحديثا فسرت هذه الظـاهرة بنظرية الجشطالت، والتي تعتمد على تفعيل منظومة مجموعـة مـن المفـردات زمنيــاً ومكانيـاً بالصــورة الإدراكية[1+] بالإضافة إلى المنظور التحليلي المادي من وجهة النظر الوظيفية والبيئية وحديثًا يضـاف لها

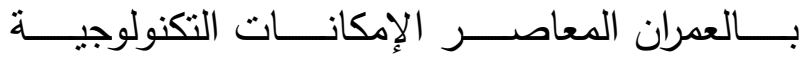
والمعلوماتية[r]. وللمفردات التكوينية للأروقة بالأفنية أثرهـا في طابع المكان والتفاعل البيئي معـه، سواء في حركة الهواء أو تكوين الظلال، ولتكوين الرواق الكثيـر مـن المفـردات المنمثلــة فـي تقاصـيله مـن 
متراً، وله مدخل ضخم يتوسط جدار المؤخرة، ويؤدي

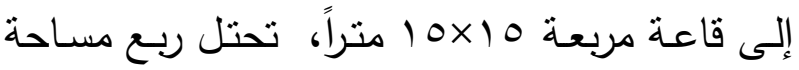
المسجد، وقد أقيم فوقها قبة عالية ألغت فكرة الفناء

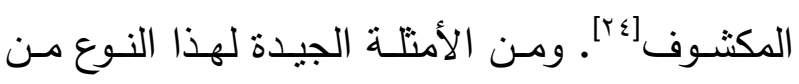
التخطبط في مدينة مشهد، جامع فرامين المبني سنة

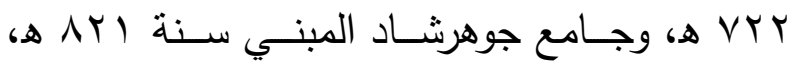

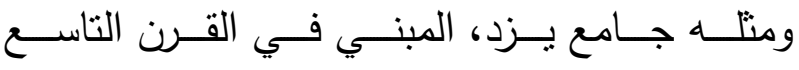

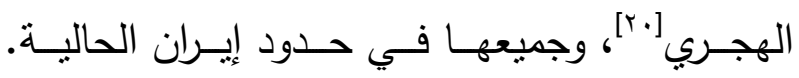

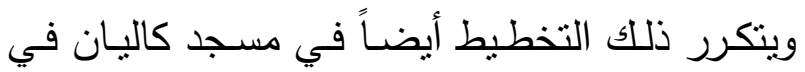
بخارى، ومسجد الجمعة في سمرقند [ـ ب]. وفي أواخر العصر المملوكي في مصر، خلت المساجد الصغيرة

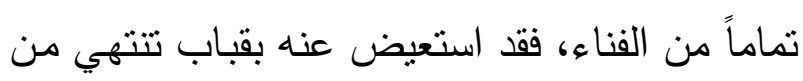

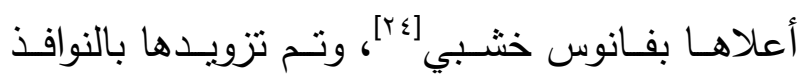

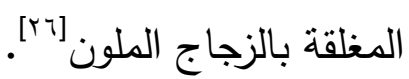

عنــ ظهـور مسـجد المدرسـة المحتـوي على الإيوانـات في العصر الأيوبي بمصـر ، ظل الفنـاء

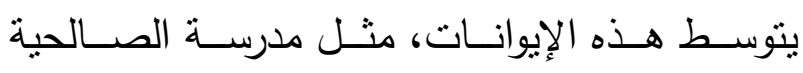
والكاملية بالعصر الأيوبي ومدرسة المنصور قلاوون

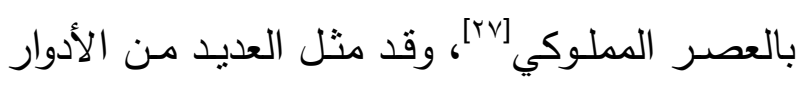

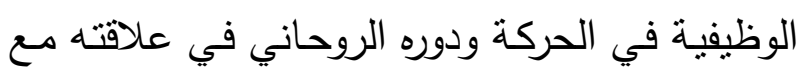
الإيوانات بالإضـافة لدوره البيئي، ولوحظ أن النسبة النية

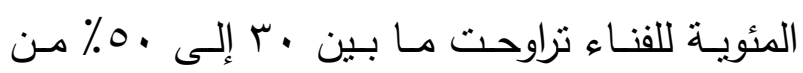
المساحة الكلية للمسجد.

وقد أخذت مسـاحة الفنـاء في التقلص نسبة لحجم المنشأ حتى تمت تغطيته في عصر المماليك

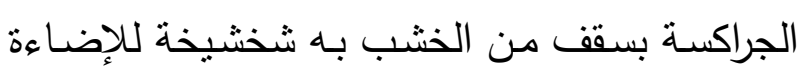

بفناء يحوي محرابا مبنيا فيه، وهذه تعد إحدى فرائد المحافظة، حيث احتوى المسجد على محرابين، واحد

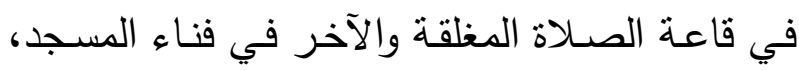

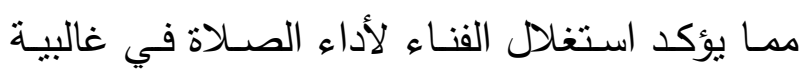

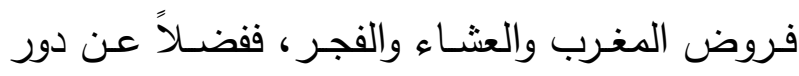

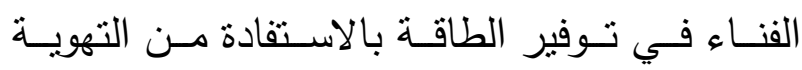
الطبيعيـة والتبريد الطبيعي، فإن هنـاك راحـة حراريـة تحتوي المصلين"[rr] وأدى تكـرار العناصـر المعماريــة فـي فنـاء المساجد التاريخية إلى انطباع هذه المفردات في ذهن المستعمل، والتي شكلت منظومة إدراكية متواتزة مع النع الزمن، والمحتويـة على عناصـر محددة كالميضـأة

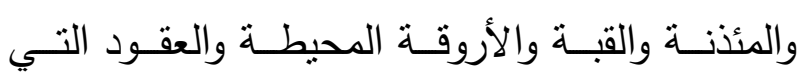

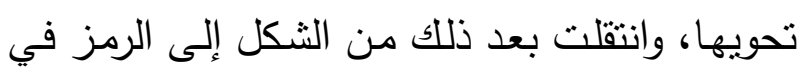

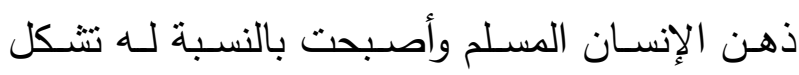

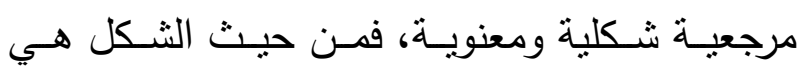
مفردات لكيان الفناء، ومن حيث المعنى ترتبط ذهنيا

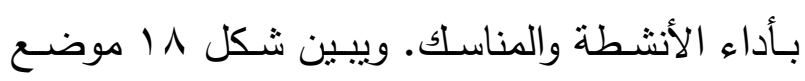

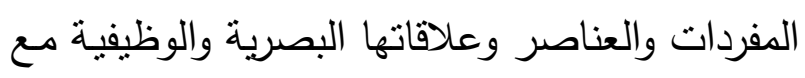
فراغ الفناء.

\section{ع. إثكالية اختفاء الفناء من المساجد التراثية}

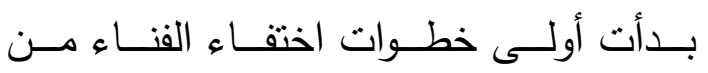
المساجد، حين استبدل بقبة مركزيـة تغطي المساحة

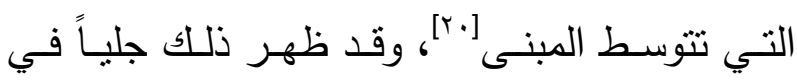

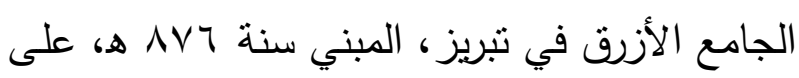

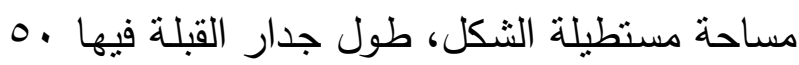


أفغانستان، حيث توجد نماذج لمساجد صغيرة ولكنها

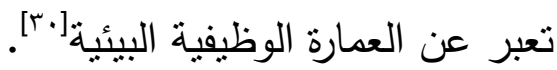

تسنتبط الدراسـة مـن العرض السـابق لاختقاء

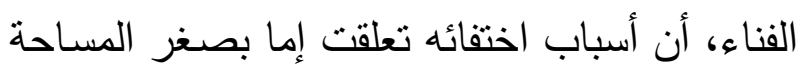
المخصصـة للمساجد، نظراً لتكدس العمران بالمدن، أو لأن الفـراغ المغلـق يـوفر حمايـة بيئيـة ومناخيـة

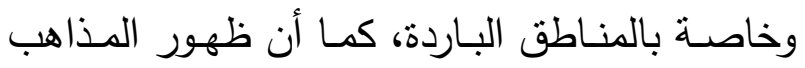
الأربعة والمدارس المخصصـة لذلك أدى إلى ظهور

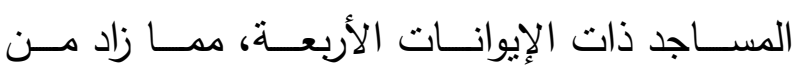
الاحتباج للفراغ الداخلي أكثر من الفراغ الخارجي. يبين شكل 19 بعض الأمتلة التي بدأ فيها اختفاء

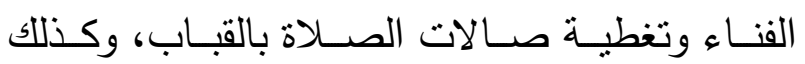
صغر مساحته بشكل ملحوظ في المساجد المحتوية على إيوانات [9، ·r]

\section{ه. الفناء بالمساجد المعاصرة التقليدية}

والمقصـود هنـا بالمسـاجد المعاصـرة التقليديـة،

التي استـمرت على الادوات وبعض المفـاهيم التـي

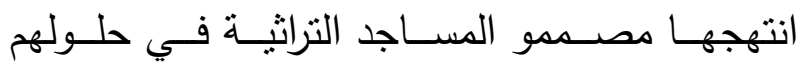
ومعـالجتهم للفنـاء بهـا ولـم تطبـق بهـا التكنولوجيـا

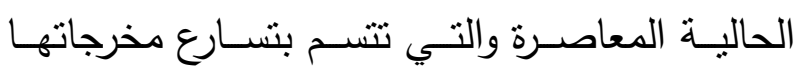
وأدواتهـا وتـؤثر بشـكل فعـال في تطـوير الدفـاهيم. ولكنها جاءت استجابة للمنطلبات تللك الفترة، وتهتم الدراسة بتحليل بعض الأمثلة المعاصرة التي وجد بها

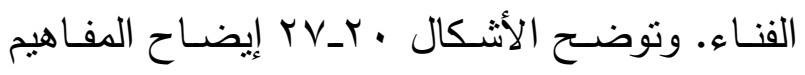

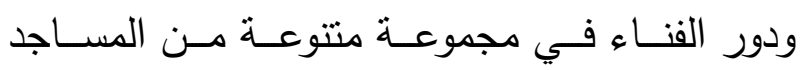

واسـتنبدل بالثـبابيك لتعـويض الإضــاءة. أمـا فـي العصر العثماني فقد احتفظت بعض المساجد بالفناء

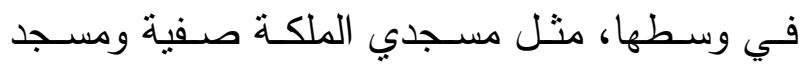

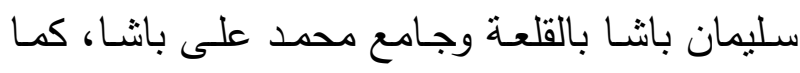

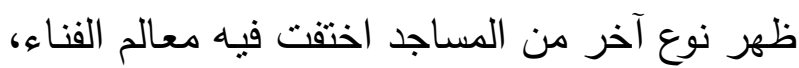

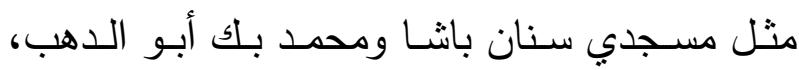

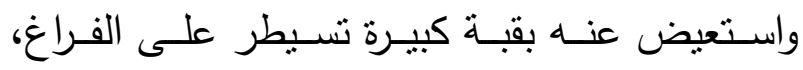
واعتمــ على الإضـاءة الخارجيـة مـن شـبابيك ذات

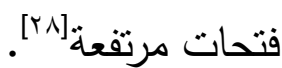

ومثل المسجد الأخضر في "آزنيق"، والمبني

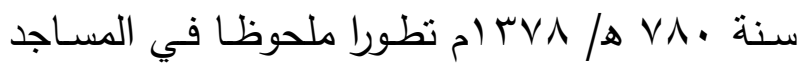
العثمانبة، فقد غطيت مسـاحة المسجد كلها بالقباب والأقبيـة، وفي نهايـة القـرن السـادس الهجـري، في لهي

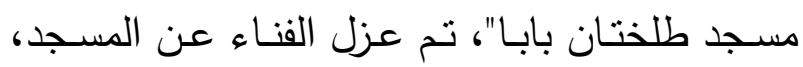
واختفى دوره الـرئيس، ولا يُحتـاج إليـه في الصـلاة؛ بسبب كبر المساحة المسقوفة بالقباب والمعزولة عن الفناء، بجدار عالي توسطه المدخل الرئيس للمسجد.

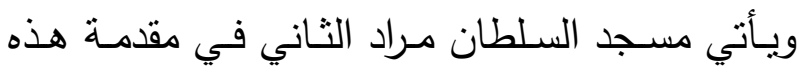

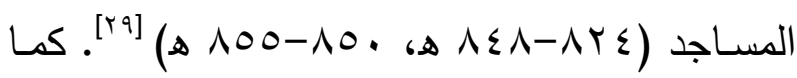
ظهـرت نمـاذج أخـرى فـي طـرز معاصـرة للطـراز

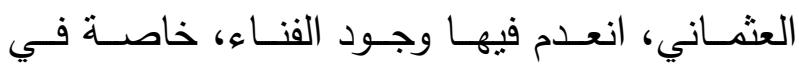
المناطق العالية من بلاد الهند وبـالد ما وراء النهر . وفي المنـاطق البـاردة مـن العـالم الإسـلامي اختفي لهـي الفناء واقتصر المسجد على قاعات الصلاة المغطاة، ومن أمتلة هذه المناطق بعض القرى الموجودة في 

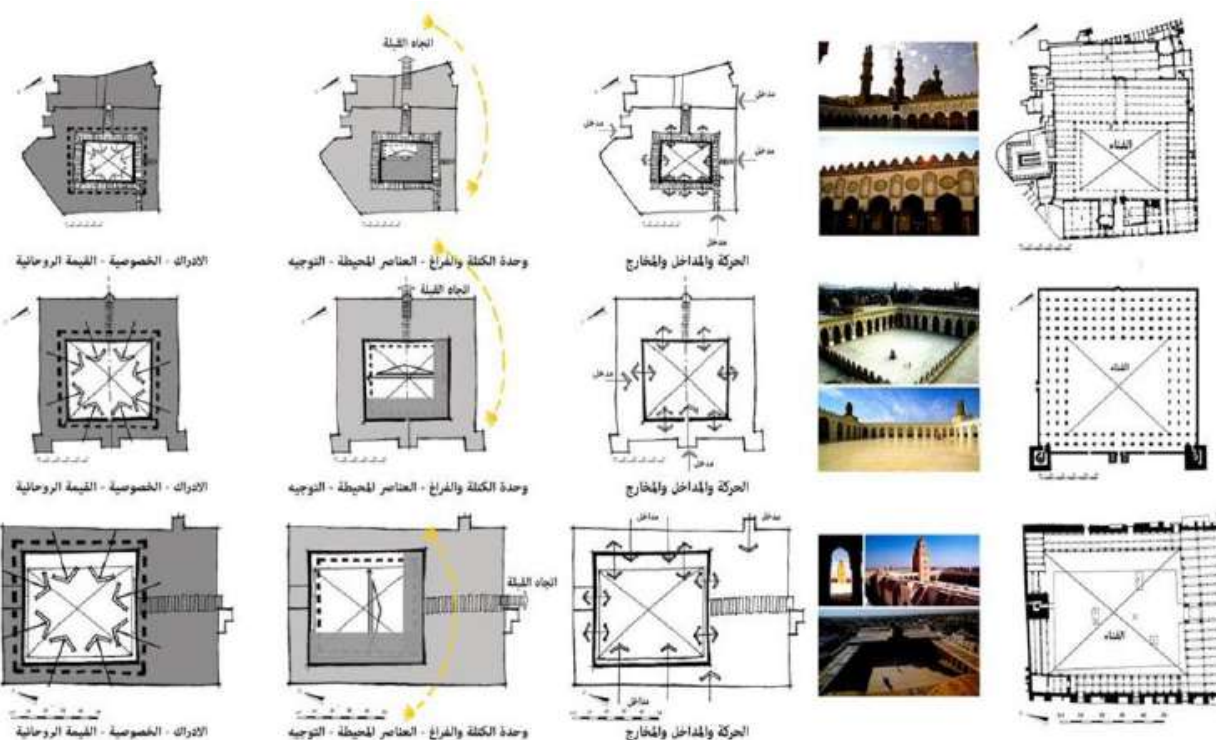

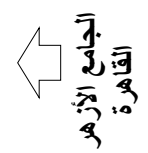
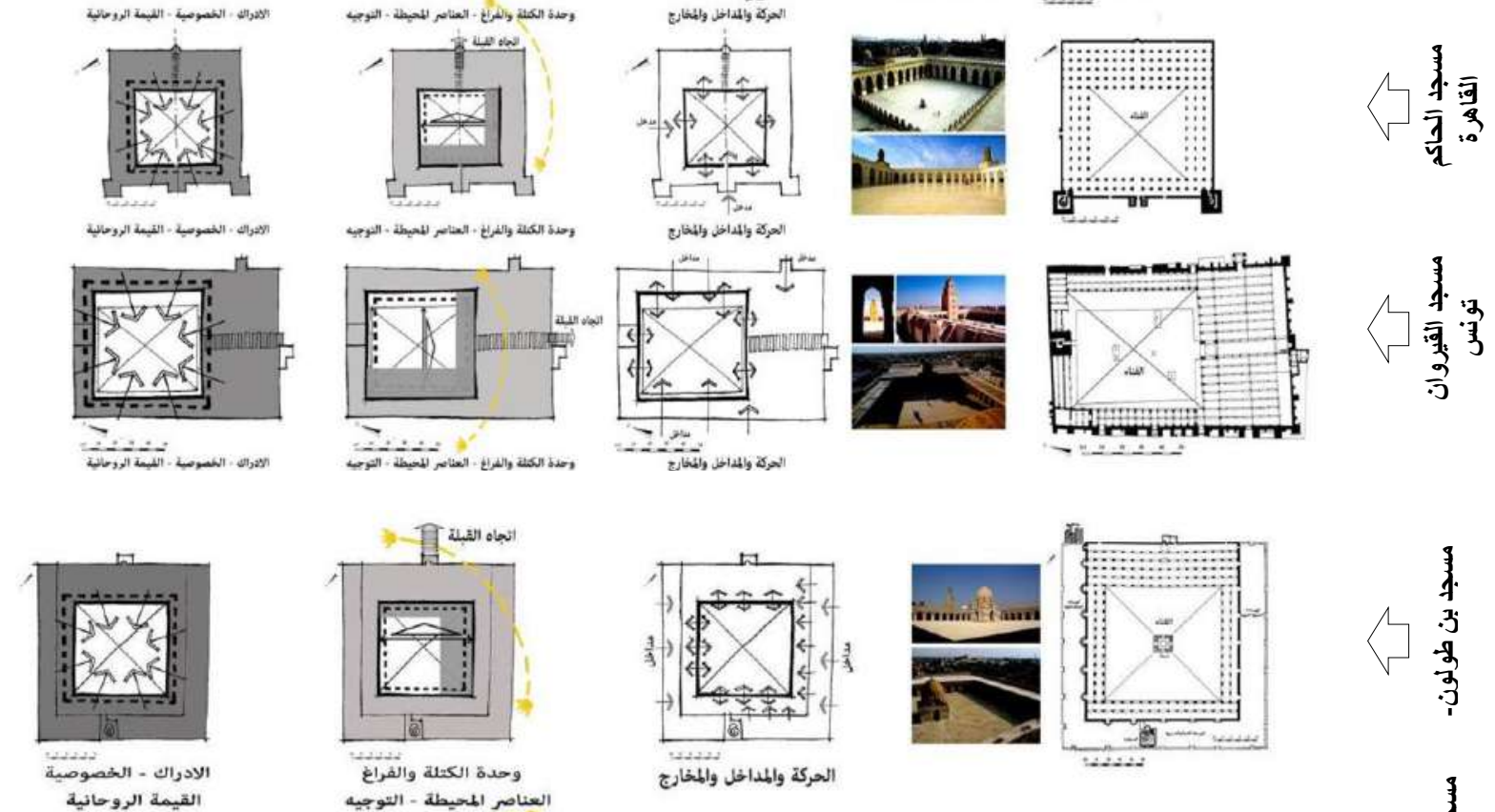

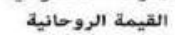
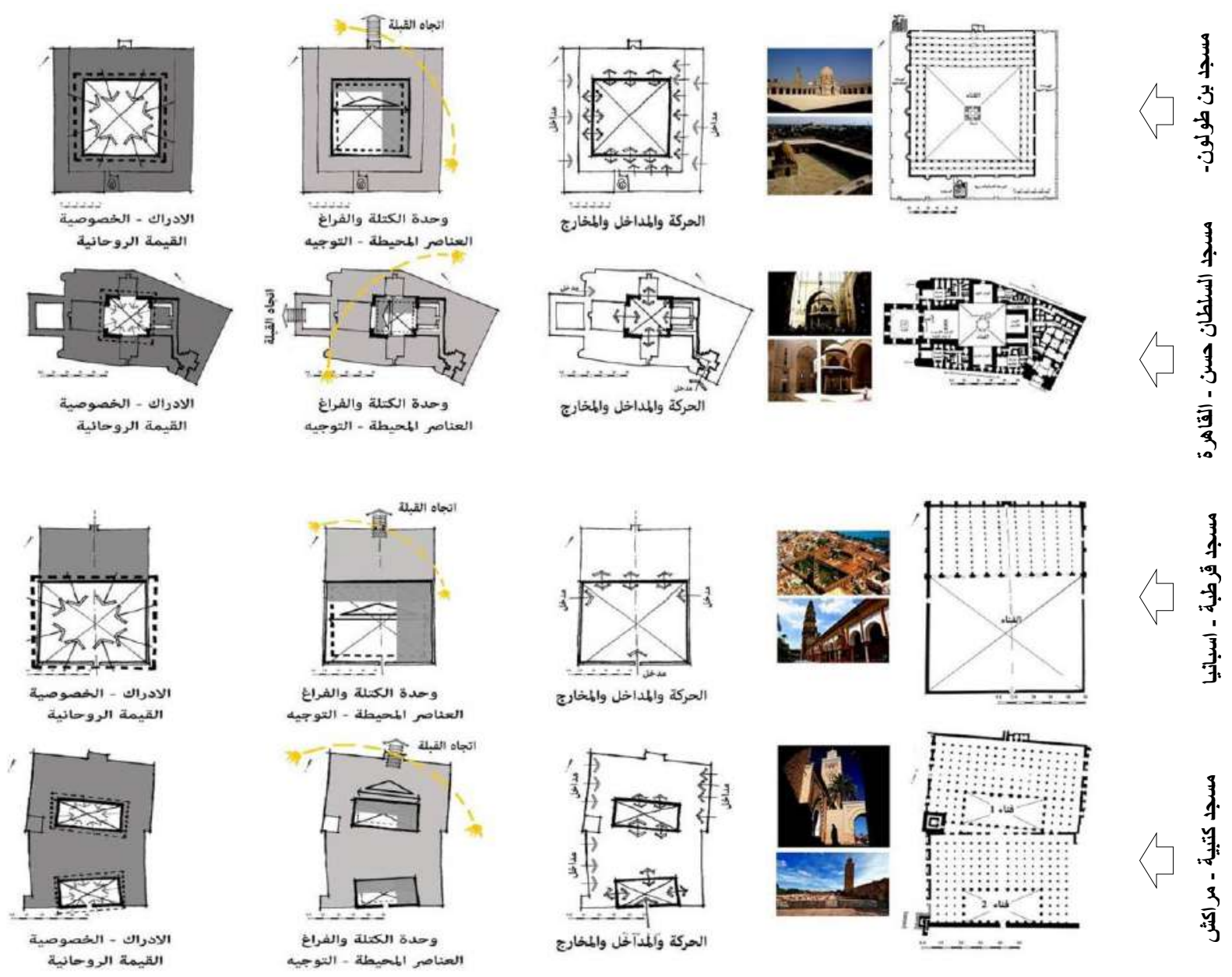

شكل 1 ا. المفاهيم التصميمية للفناء بالمساجد المختارة للاويلات المستقلة في مغرب العالم الإسلامي (الباحث) 


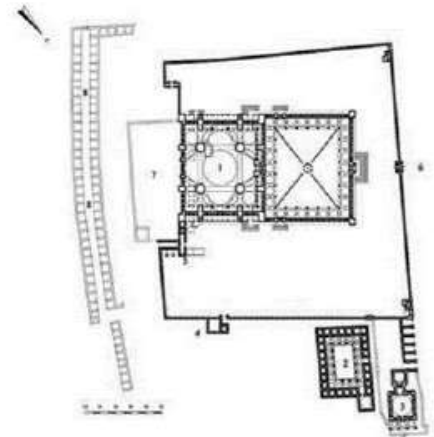

مسجد السلطان أحمد، تركيا، ؛ 1 ـ ـ أهـ الفناء

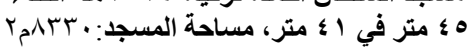

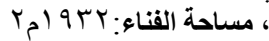

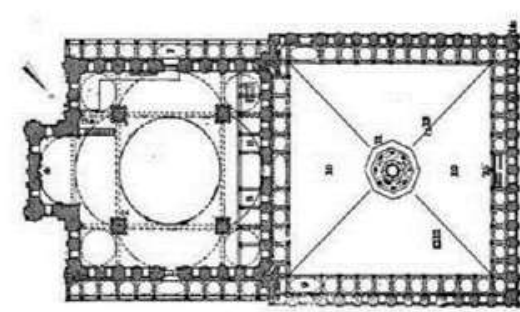

$\because 2=-2$

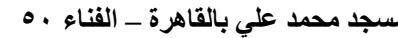

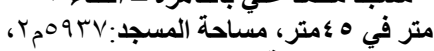

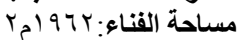

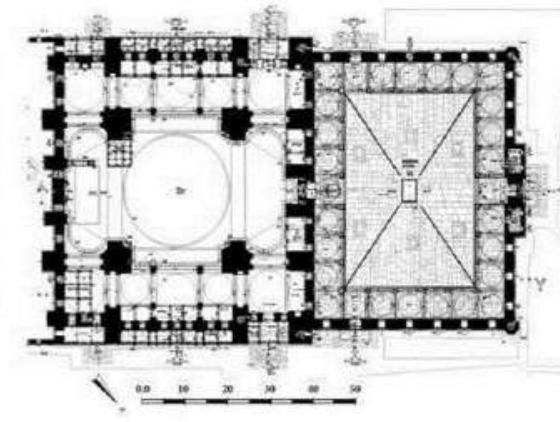

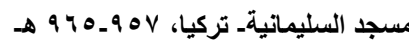

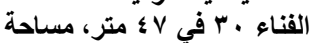

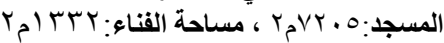

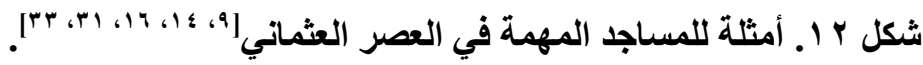

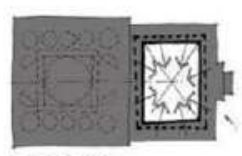

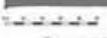

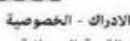

القيمة الروجانية
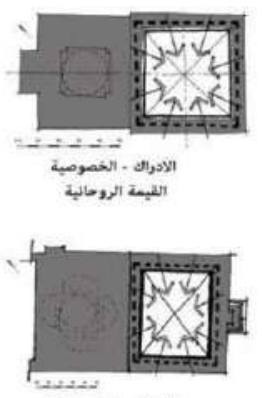

الإدراك - الخصوصبة الوخانية
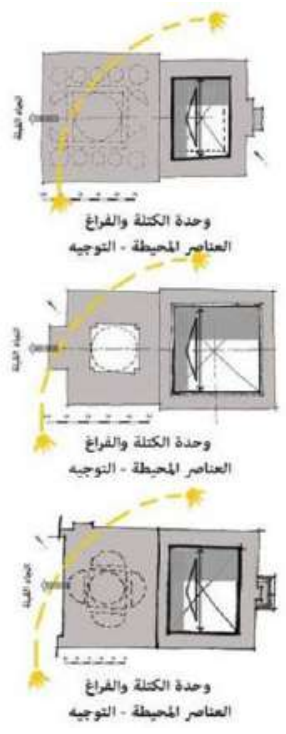
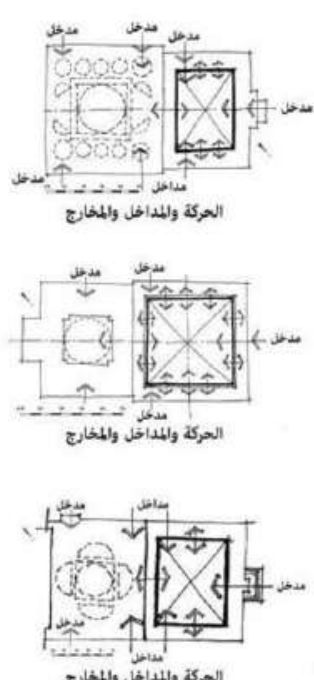

الحركة والمداخل والملخارح
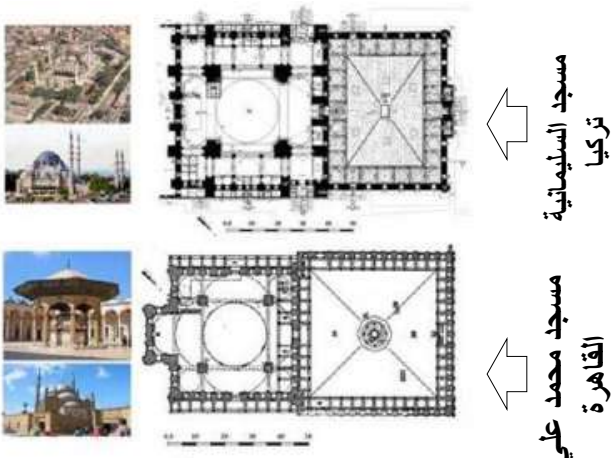

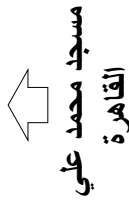

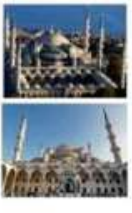

شكل با ـ المفاهيم التصميمية للفناء بالمساجد المختارة في العصر العثماني (الباحث).

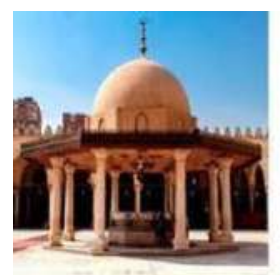

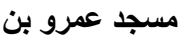

العاص

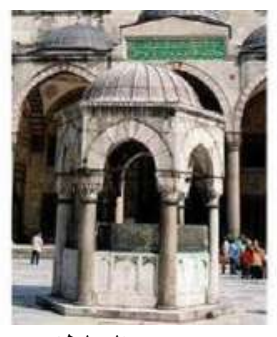

مسجد السلطان احمد المبطان

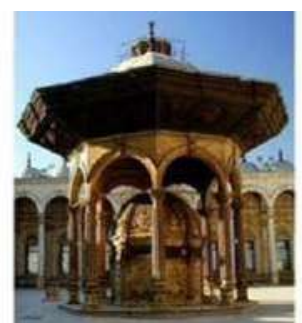

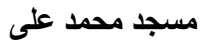

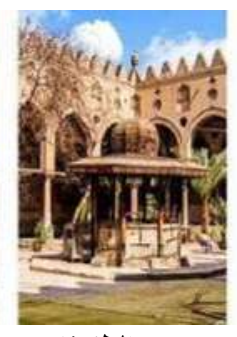

مسجد الطنبغا

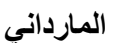

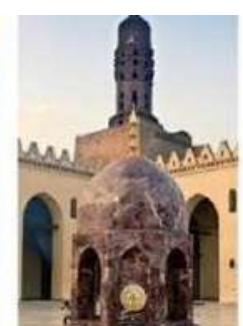

مسجد الحاكم

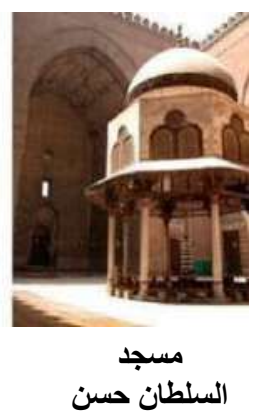

شكل ؛ ا. للميضأة دور وظيفي في الوضوء وتثثكيلي بكونه عنصر مركزي بالفناء يمثل علامة مميزة

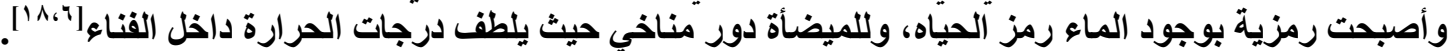




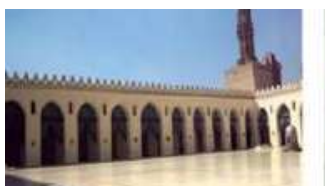

مسجد الحاكم

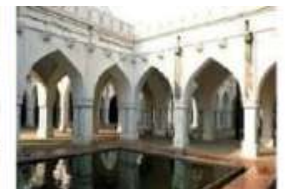

مسجد نجم الاين

دلهي

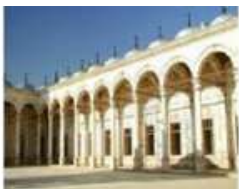

مسجد محمد على
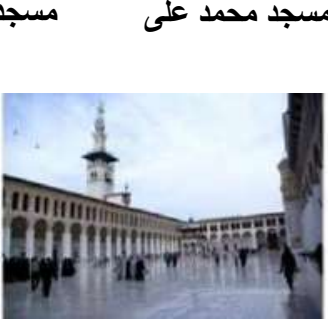

المسجد الاموي

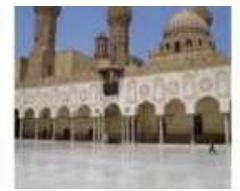

الجامع الازهر

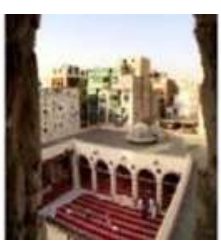

مسجد الشافعي

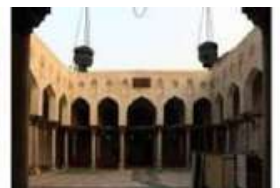

مسجد الصالح طلائع

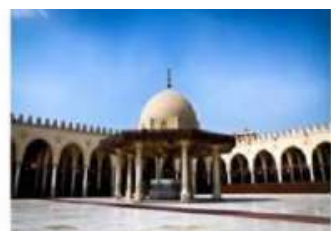

مسجد قوة الاسلام مسجد عمرو بن العاص

شكل ه 1 ـ يمثل الرواق العنصر التثكيلي المحدد لحيز القناء بغالبية المساجد، بالإضافة لاوره المناخي في التظليل

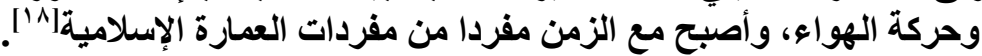

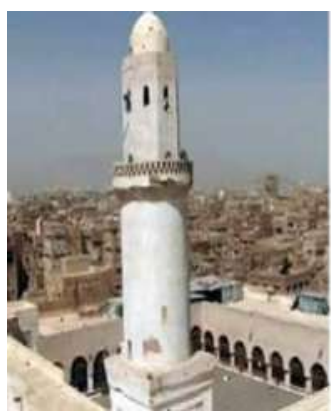

الجامع الكبير بتونس الجامع الكبير بصنعاء

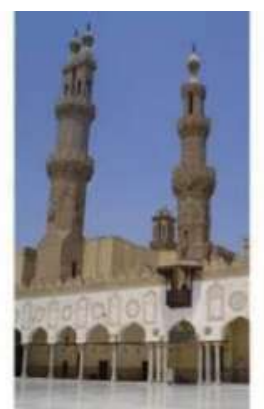

الجامع الأزهر

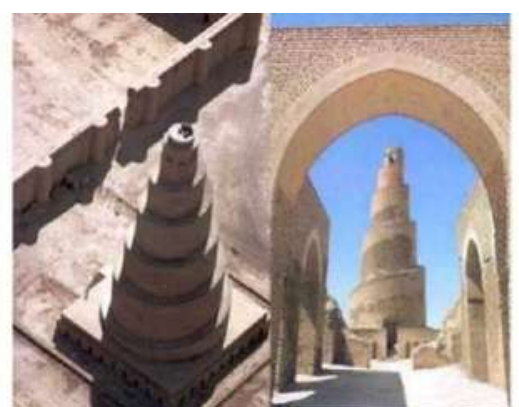

مسجد سامراء

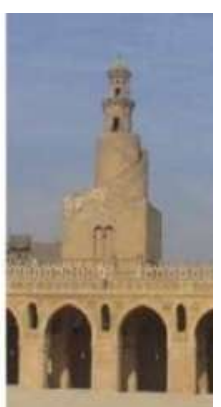

مسجد بن طولون

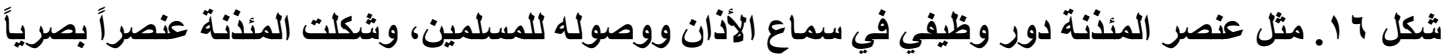

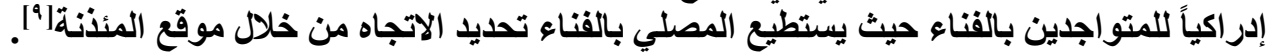

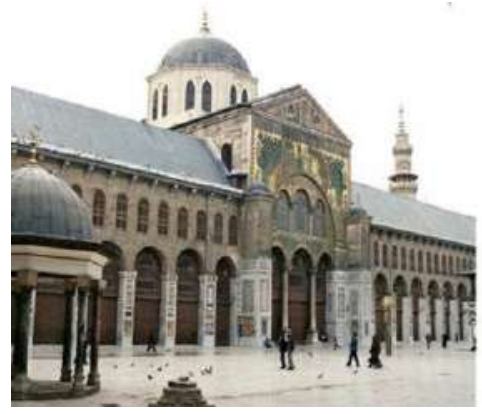

المسجد الأموي

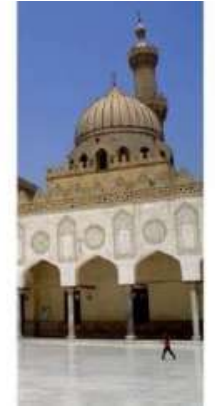

الجامع الأزهر

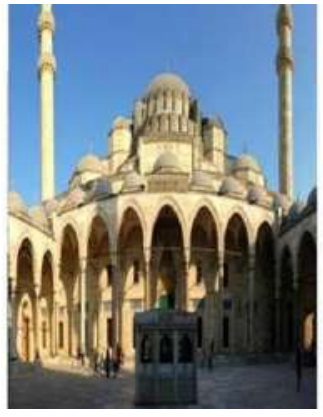

مسجد السليمانية

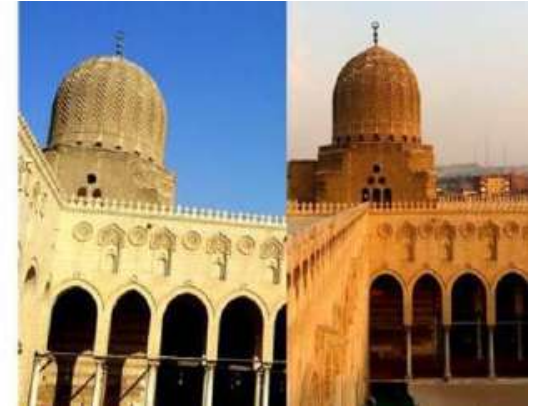

مسجد المؤيد

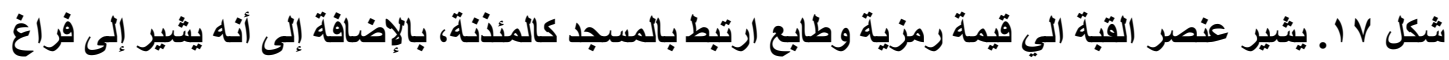
صالة الصلاة وعلاقتها بموضع رمزيع الفناء في غالبية المساجد. 


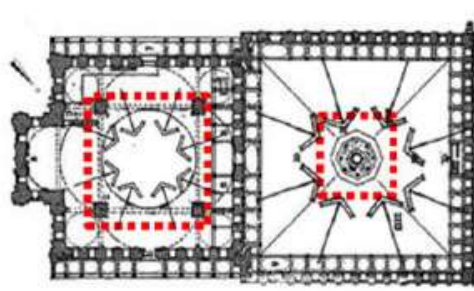

$\because "=-1=$

جامع محمل علي
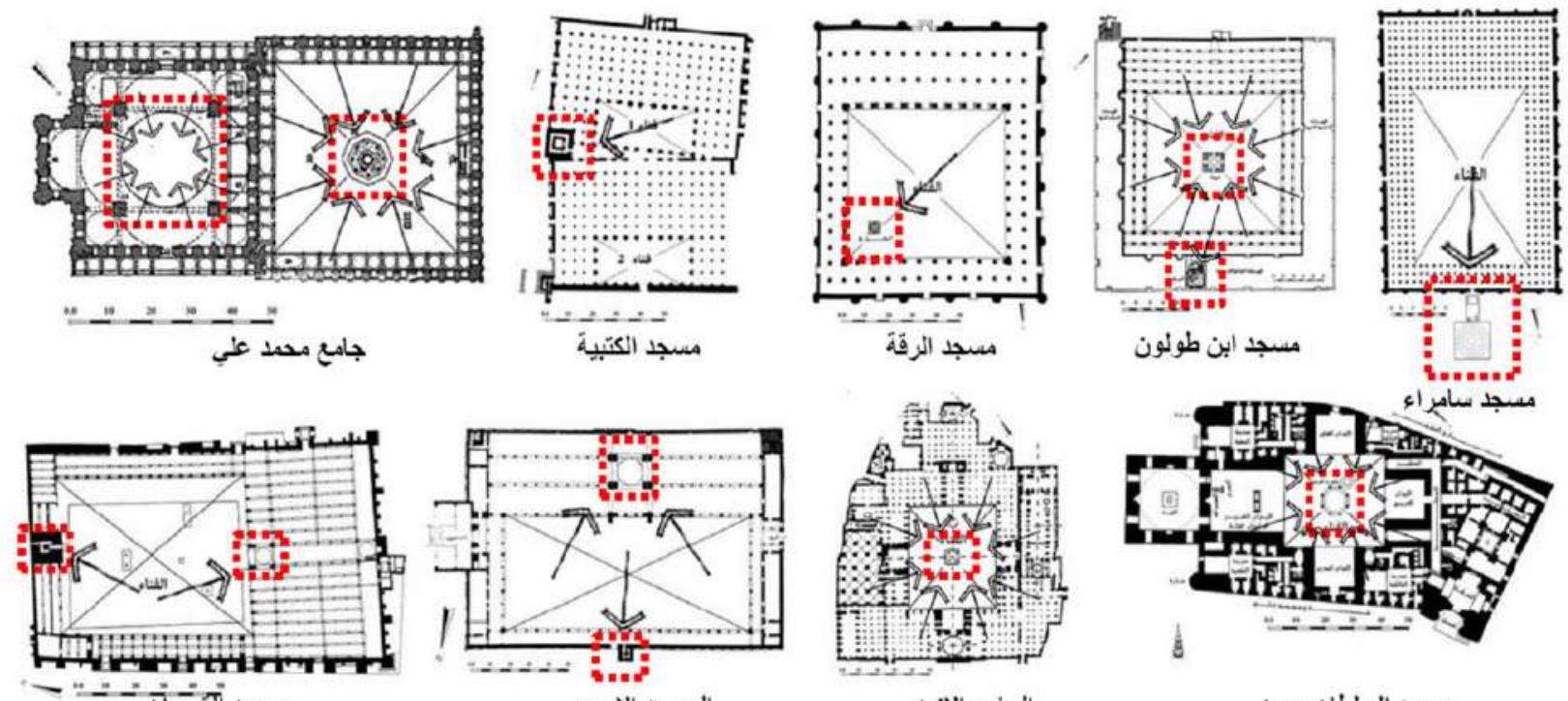

مسجد آلهيروتَاتن
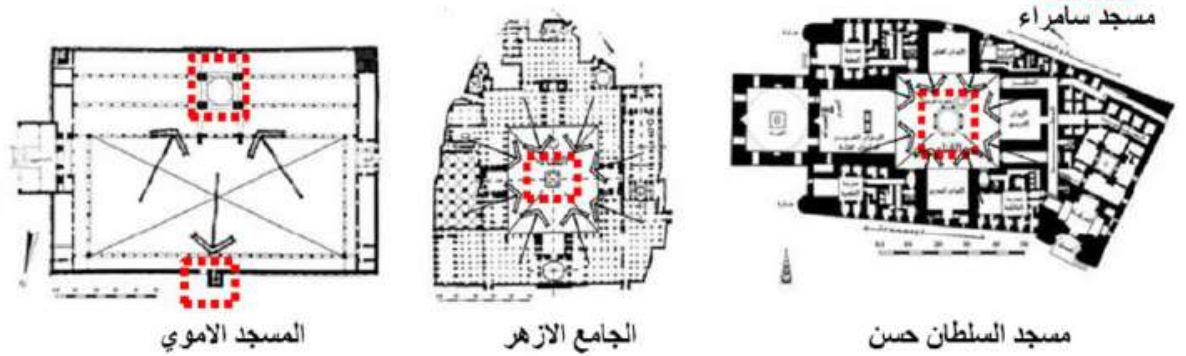

مسجد السنطان حسن

ولكي تمتث هذه الاحاسيس في جنباته. والأهمية الرمزية للفناء في احتواء النظام الطبيعي ضمن منطقة الصـلاة لتوفير مساحة إضافية لصلاة الجمعة]"]

يوضــح شـكل ع ب ثلاتهـة أمنتلـة منتوعـة الفكـر لمساجد معاصرة بثلاث بيئات مختلفة، حافظ المعماري راسم بدران في تصـيمه لفناء مسـد الإمـام تركي بن عبداله بالرياض على للتوازن بين القيم الموروثة وبين الاحتياجـات المعاصـرة المتغيرة بجانب مراعاته للتقافة والمورفولوجيا والإيكولوجيا، ومنها أصول مفاهيم علاقة الفناء بالمسـد من حيث الوحدة، وجعله كيانـأ ضــن كيانات المسجد، وتوجيه الضـلع الأكبر لمستطيل الفناء ناحيـة القبلـة، وحقـق جانبـا كبيـرا مـن الظــلال للفنـاء بدراسـة الارتقاعـات وعـرض الفنـاء، لرفـع كفــاءة أداءه البيئي بمنطقة الرياض ذات المناخ القاري، مـع تطويع ومعاصرة مواد البناء والتكنولوجيا.
اهتم حسن فتحي بجذور المفاهيم الأولية للفناء بالمسجد كقيمة الوظيفة والوحدة والسمو، ومركزا على القيم الروحيـة، وتعظيم القيمـة البيئيـة والتركيز على الجانـب المنـاخي بشــل خـاص فـي أعمالـه، مـع تطويعه لمواد البناء المتاحة. ويعتبر حسن فتحي أن الفنـاء يعمـل داخـل منظومـة منكاملـة مـع المســد بمفرداتـه وفراغاتـه لكـي يصــل المسـتعمل للراحـة الحرارية المناسبة.

ذكر عبـد الواحـد الوكيـل واصـفا علاقـة الفنـاء وخصائصسه، بـأن مسـد الفنـاء المركزي قد بلـن درجـة من الصفاء والنبل المعماري، كما نجد ذلك في مسجد ابن طولون في القاهرة، وبسمو المسجد بالفناء الرئيسي الذي يعتبـر ضـروريا في امتداد الحيـز الفراغي إلى أعلى، ليمـنح المسـتعملين السـمو للسـماء والروحانيـة 


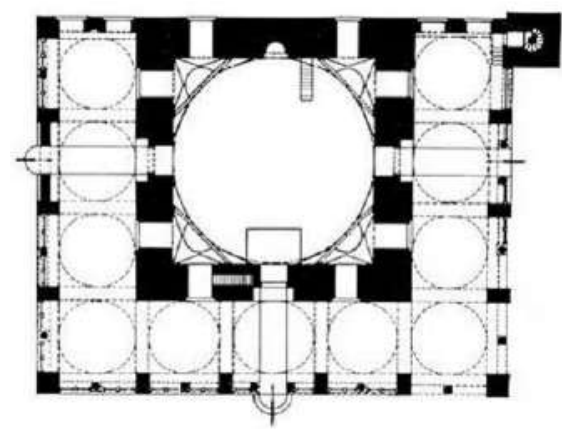

مسجد سنان باشا-بولاق -القاهرة

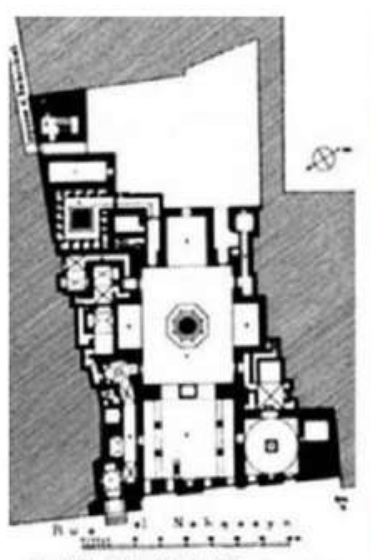

مسجد ومدرسة السلطان برقوق بالقاهرة

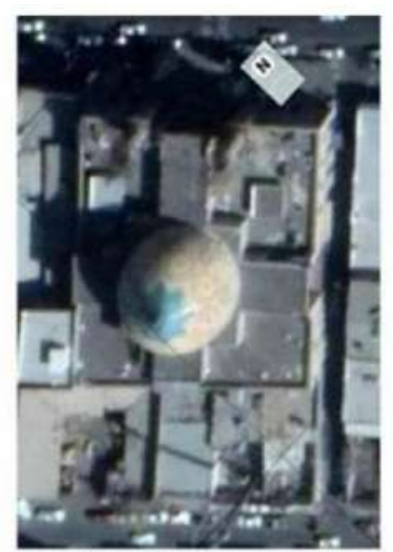

مسجد مدينة مثهد - ايران

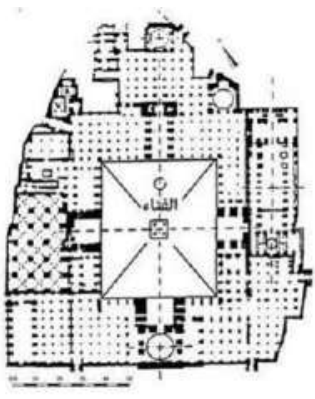

مسجد الجمعة في اصفهان

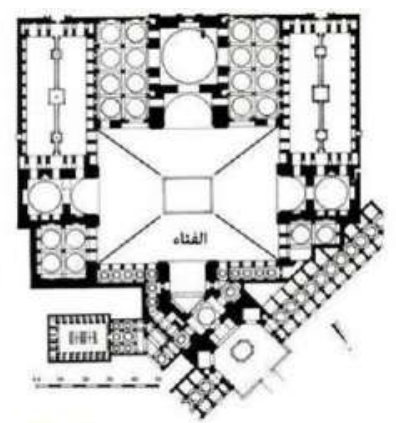

مسجد الثاه عباس في اصفهان
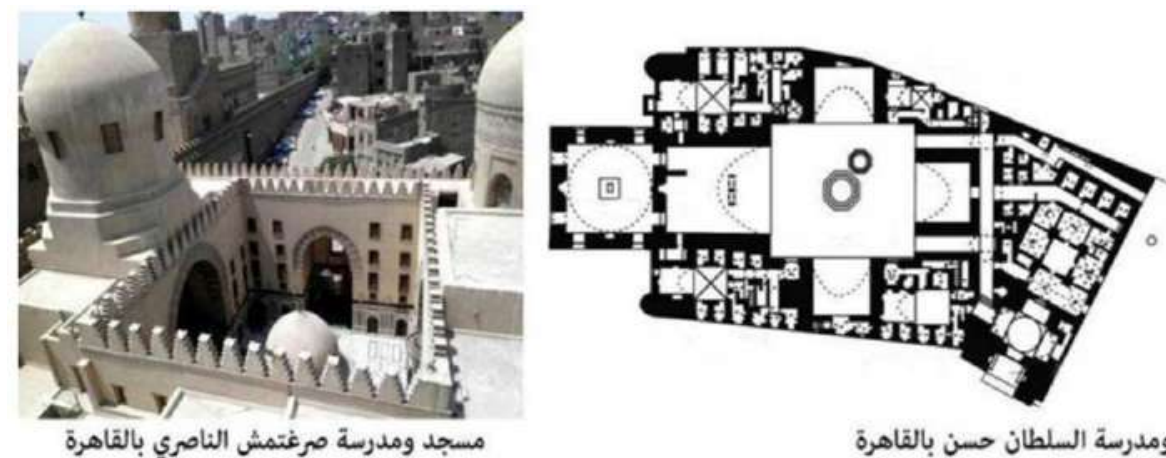

مسجد ومدرسة السلطان حسن بالقاهرة

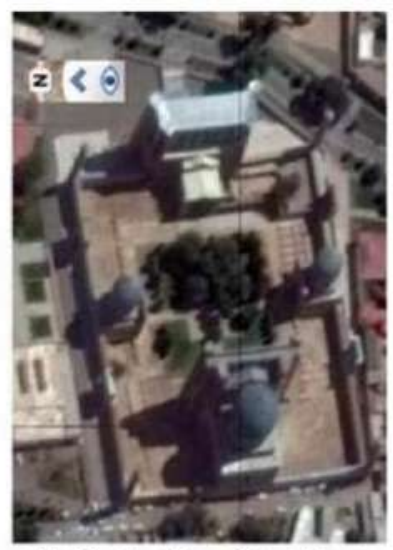

مسجد الجمعة في سمرقند - اوزسباكيستان

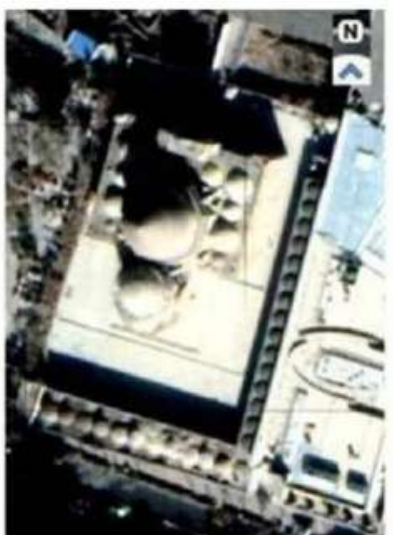

الجامع الازرق في تبرير- ايران

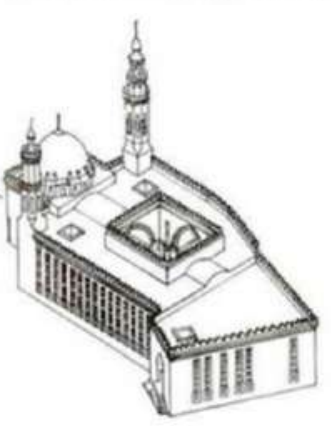

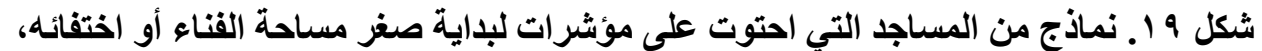

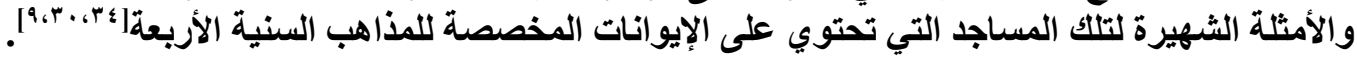

المحوري في المسقط المعداري ووجـود الفناء على

محور مهم.

مسـجد الثـيخ زابـد، وهـو منبـع لنمـوذج خـروج

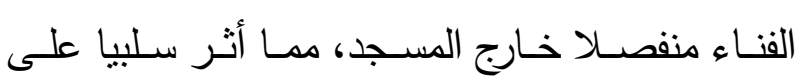

المفاهيم الأساسية للفناء الذي يتوسط فراغات المسجد
مسجد الزهراء، تصميم د. عبد الباقي إبراهيم،

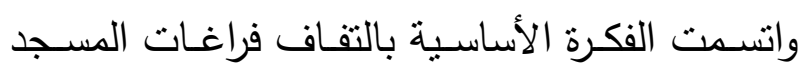
حول الفناء المركزي محققا التكامل البيئي الوظيفي بـين فراغـات المسـجد والفنـاء، واسـتعمال الفنـاء مـع

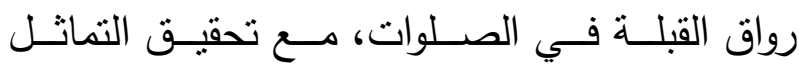


للاستتساخ المنطابق للمفردات المكونة للفناء مما أثر سلبيا على شخصية وطابع الفناء والمسجد.

\section{ד. الفناء بالتوجهات المعاصرة غير التقليدية}

مهـا لاشـك فيـه أن التعامل مـع الوضـع الراهن

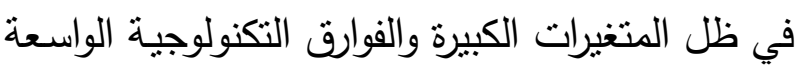
والمتسارعة بين عصر استخدام الفناء التقليدي داخل المسجد والعصر الحالي، أمر يحتاج إلى منهج مركب إنب

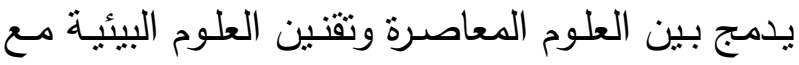

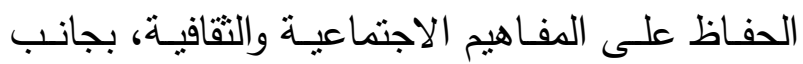
دعـم عمليـات الإحبـاء للمفـردات التراثيــة بصــورة معاصــرة وغيـر تقليديـة وربطهـا بالاحتيـاج الفعلـي

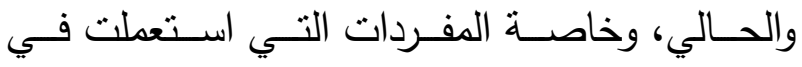
الماضي بنلقائية وأثنتت أنها عالية الأداء في بيئاتها. ولعبت التكنولوجيا والفكر المتحرر من القيود والقوالب

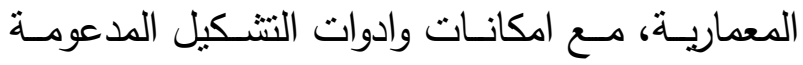
بالتكنولوجيا، دورا مهما في صياغة متحررة لمفهوم العلاقة بين الفناء والمسجد، ويوضح شكل هب بـ بعضًا من هذه التوجهات والمفاهيم.

V. العوامل التي أثرت على تكوين الفناء

ادى اختلاف المناخ ومواد البناء وأساليبه في مختلف الأقاليم والبلاد الإسـامية وكذلك تأثثر فنون

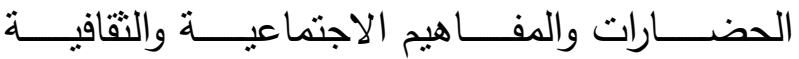
والاحتياجات البيئية والروحية إلى الحاجة إلى تواجد

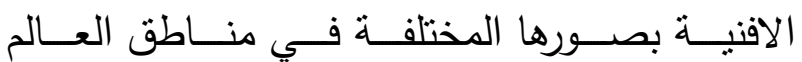
الإسلامي، ويمكن إيجاز العوامل المؤثرة في الآتي:
ويعمل معـه في منظومـة وحدة التكوين وفاقدا للتندج الإدراكي لاتصـال الفنـاء بالسماء، حيث يتم الدخول الرئيسي للمسجد من خلال الفناء ضخم المقياس والذي يؤثز سلبيا على القيم الروحية والبيئية.

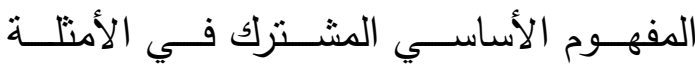
الموضحة للمساجد الحديثة بالعين هو خروج الفناء خارج كتلة المسجد واحاطته بالأروقة، مثل مفاهيم النماذج العثمانيـة بتركيا، بالرغم من أن منـاخ وبيئة

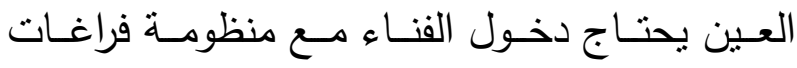
المسـجد لتكامـل المنظومــة المناخيــة وتحقيـق دورة

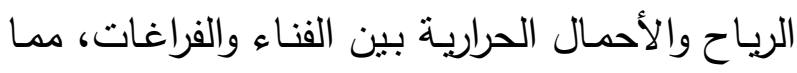

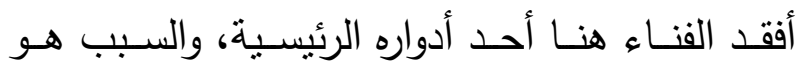
الاعتماد على أجهزة التكييف في الفراغات الداخلية، وافتقد الفناء أيضـا جزءاً من الثعور بتدرج الإضـاءة والذي يساعد على الارتباط بين فراغ المسجد والفناء،

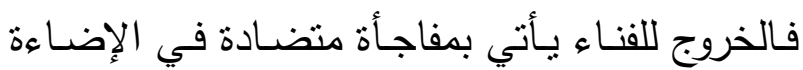

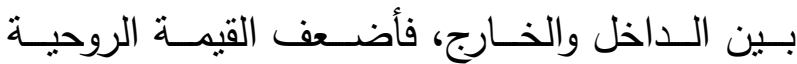

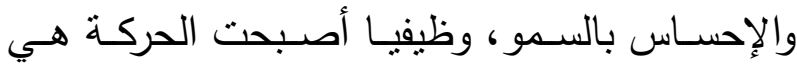
الدخول من الفناء وليس الدخول للفناء، مما أدى إلى فقدان الفراغ لجزء منه في الحركة والدخول والخروج

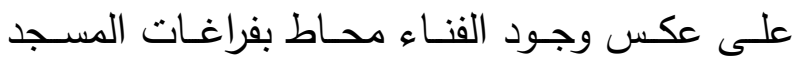

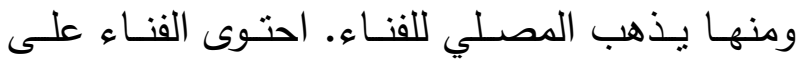
مأذنتين بالرغم من أنها أصبحت رمزا تشكيليا بشير للمسجد فقط. يتم الإدرالك البصري للفناء ولكن كوحدة

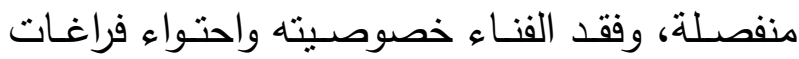
المسـجد لـه. وافتقـر تصـميم الفتـاء للتتـوع، نتيجـة 


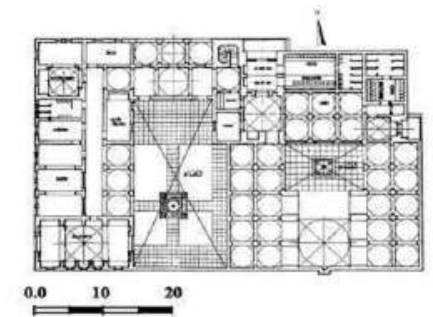

$\stackrel{0.0}{=10}{ }^{20}$
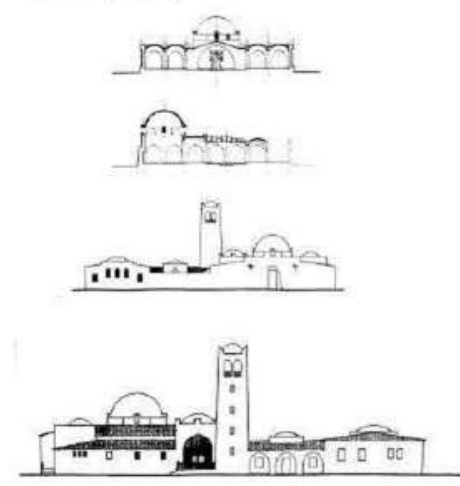

مسجد روكسبيري - بوسطن - الولايات

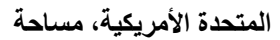

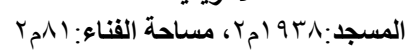
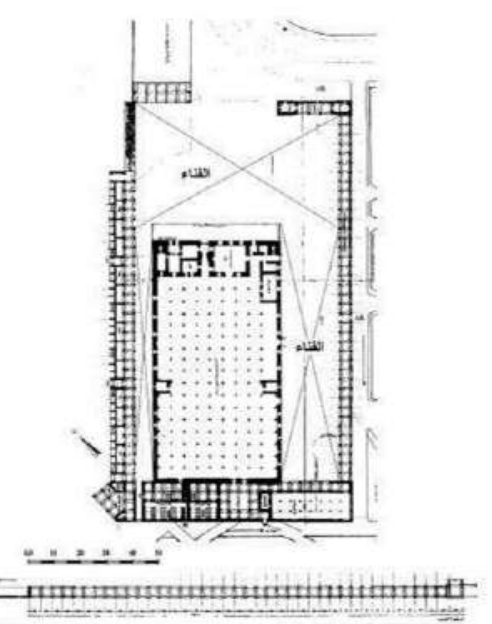

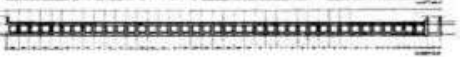
‥1 مسجد بمنطقة العارف بالله السيد احمد الباري

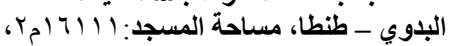

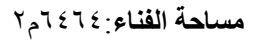

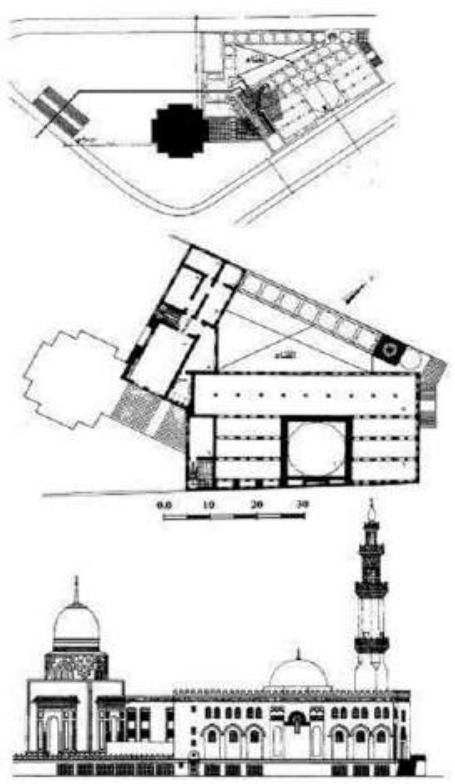

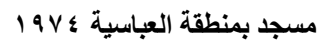

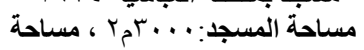

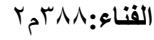

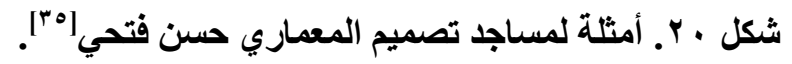
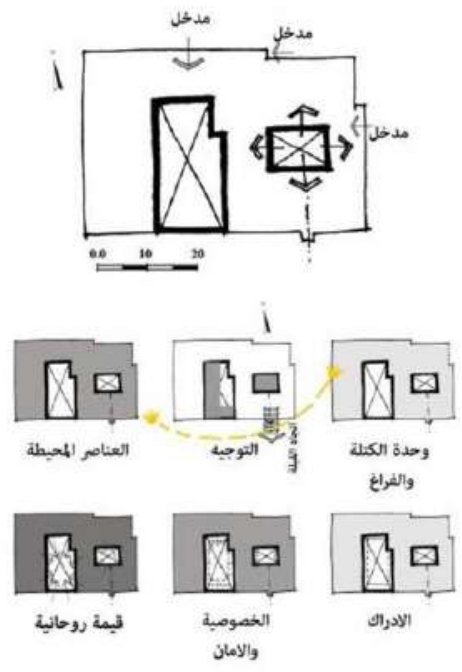

مسجد روكسبيري - بوسطن - الولايات المتحدة الامريكية - بونية الو

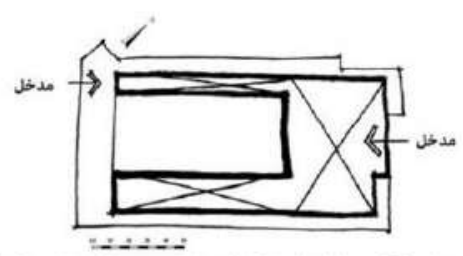

علاقات الحركة بين الفناء وفراغات المسجد والمداخل والمخارج
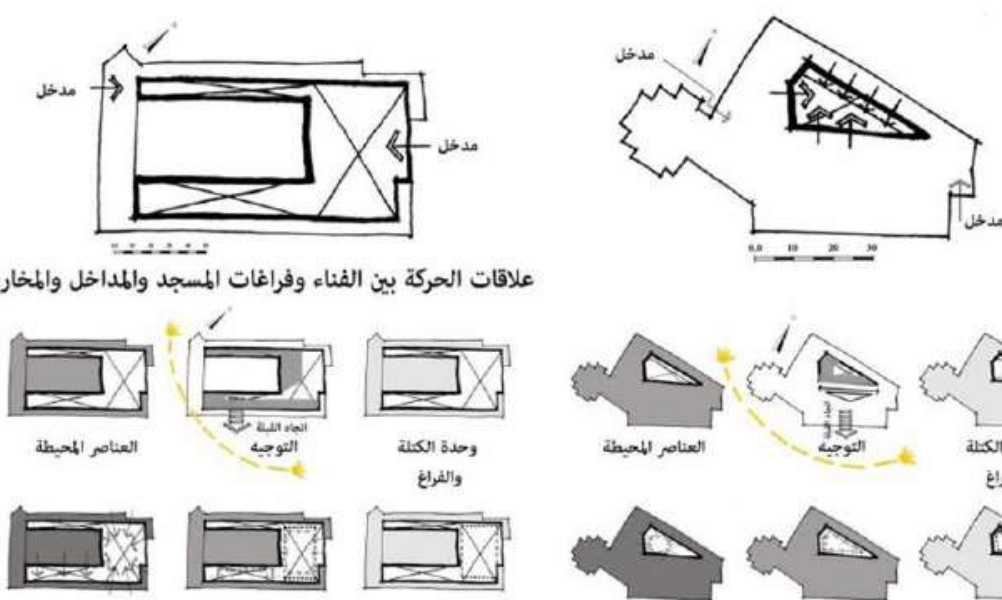

قيمة روحائية
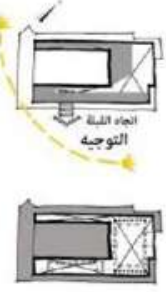

الغصومية

مسجد بمنطقة العارف بالله السبد احمد البدوي - طنطا

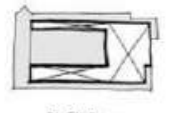

وحدة الككلة
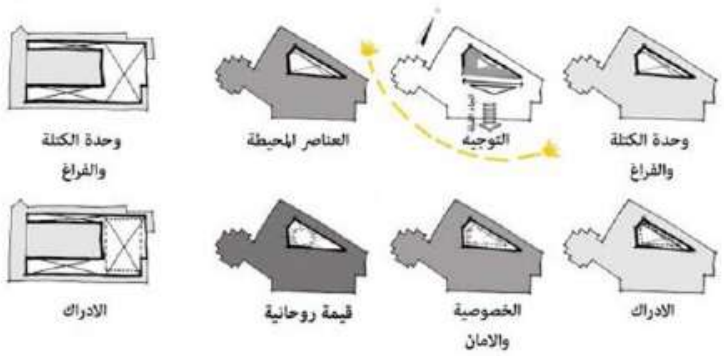

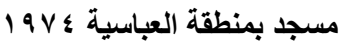

شكل ا Y. المفاهيم التصميمية للقناء لمساجد تصميم المعماري حسن فتحي. 


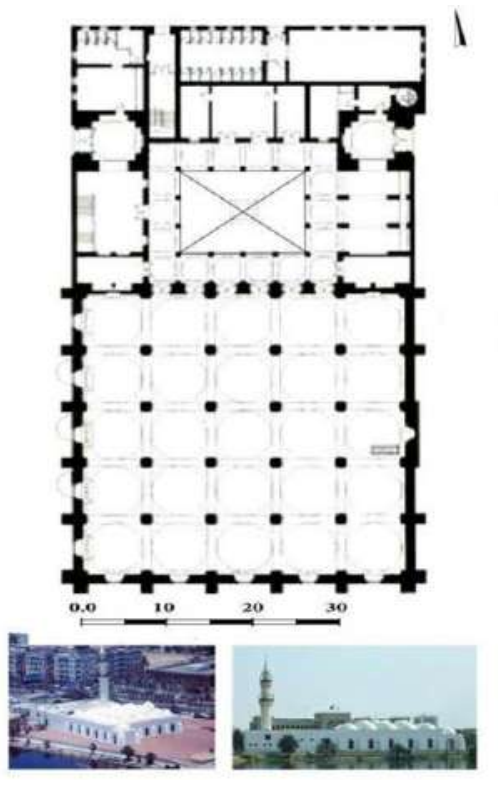

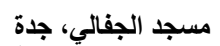
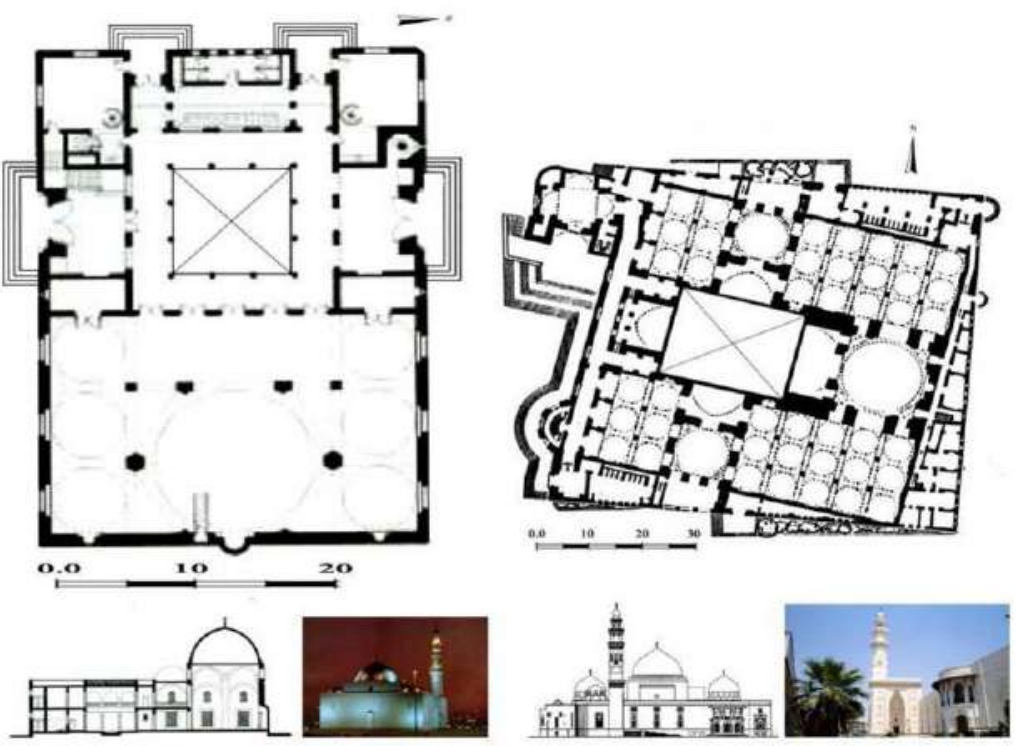

مسجد السليمان، جدة إمبان العدان

مسجد الملك سعود، جدة

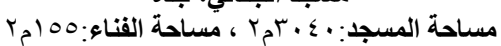

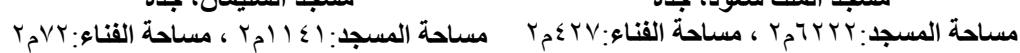

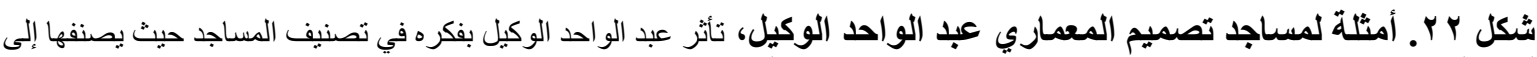

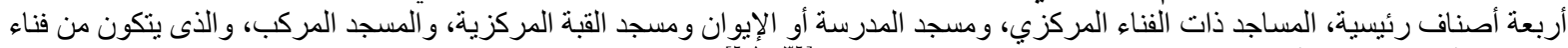

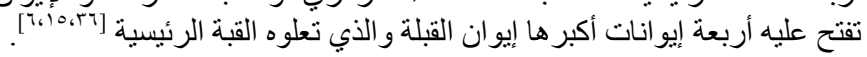
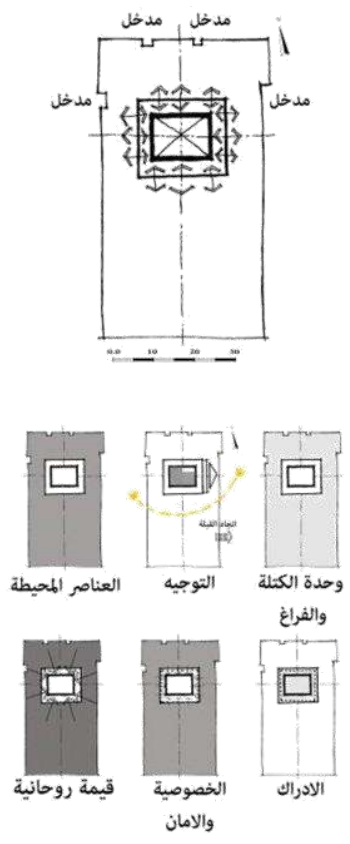

مسجد الجفالي، جدة
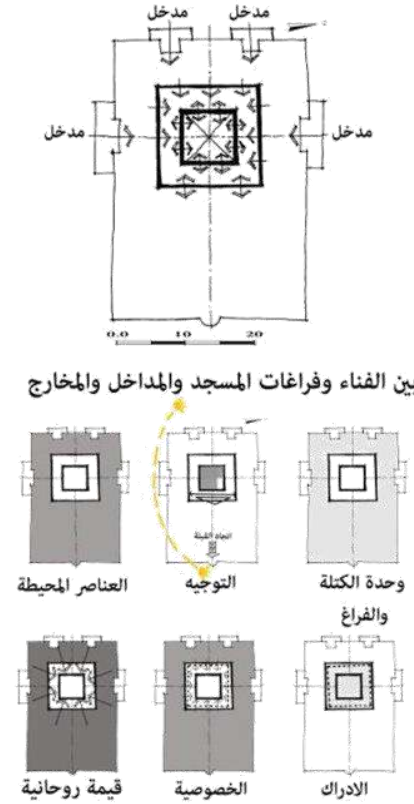

مسجد السليمان، جدة

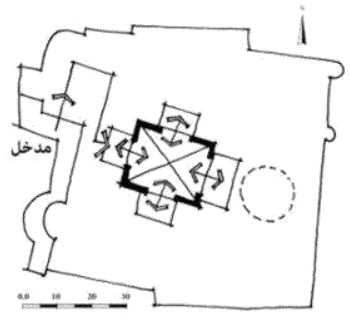

علاقات الحرك
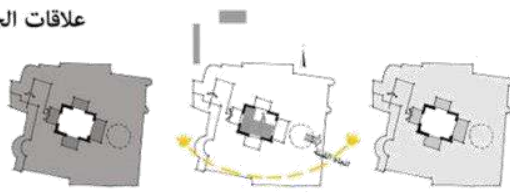

العناصر المحيطة

التوجيه

وحدة الكنلة

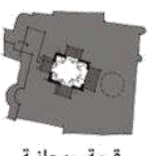

قيمة روحانية
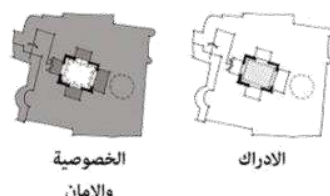

مسجد الملك سعود، جدة

شكل ب ץ . المفاهيم التصميمية للفناء لمساجد تصميم المعماري عبد الواحد الوكيل (الباحث). 

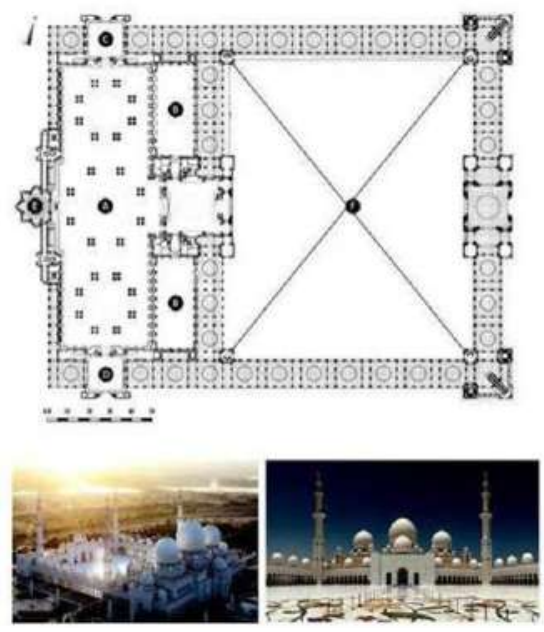

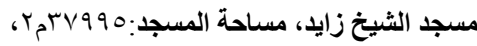

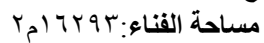
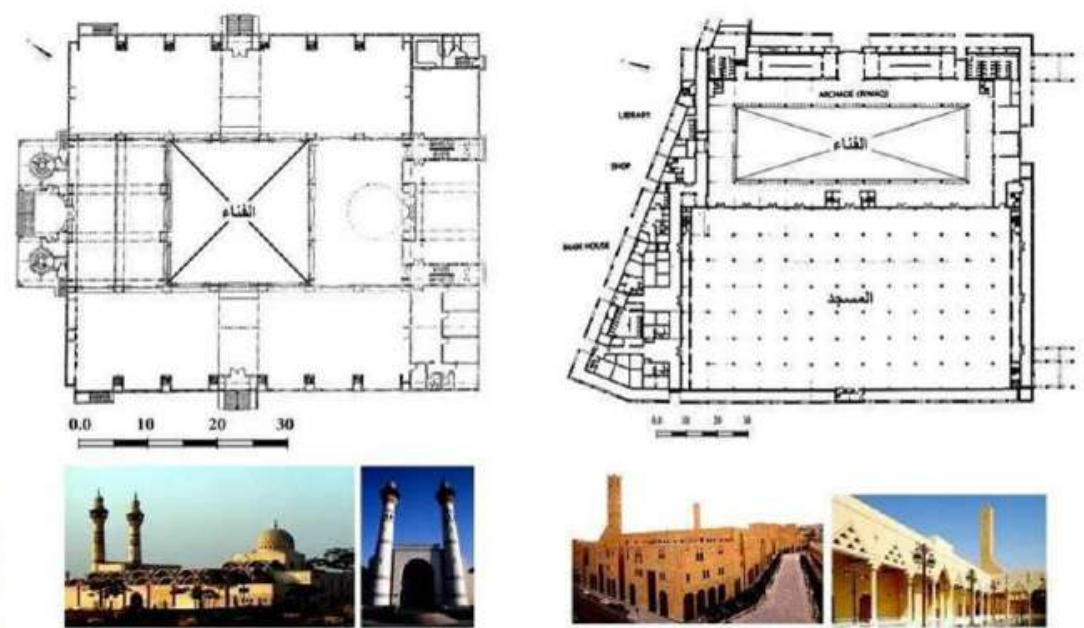

مسجد الزهراء، القاهرة، مصر، مساحة

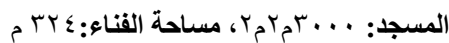

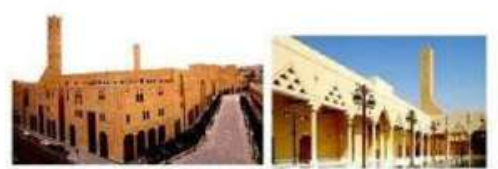

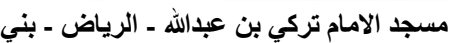

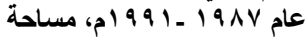

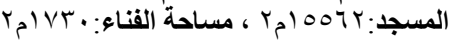

شكل ؟ Y. أمثلة لمساجد حليثة متنوعة البيئات، الرياض، القاهرة، والإمارات العربية.
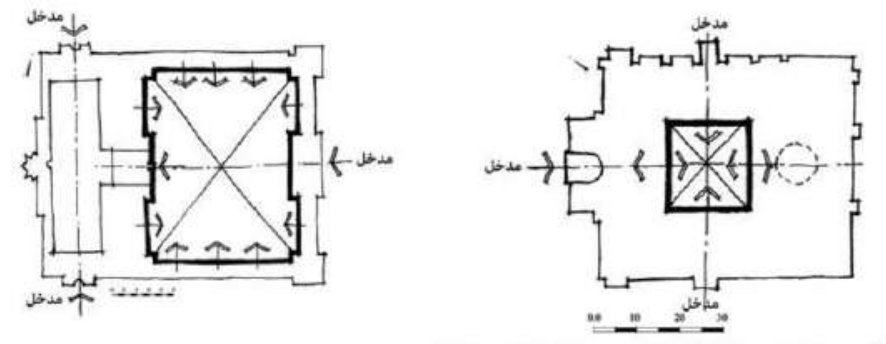

علاقات الحركة بين الفناء وفراغات المسجد والمداخل والمخارج
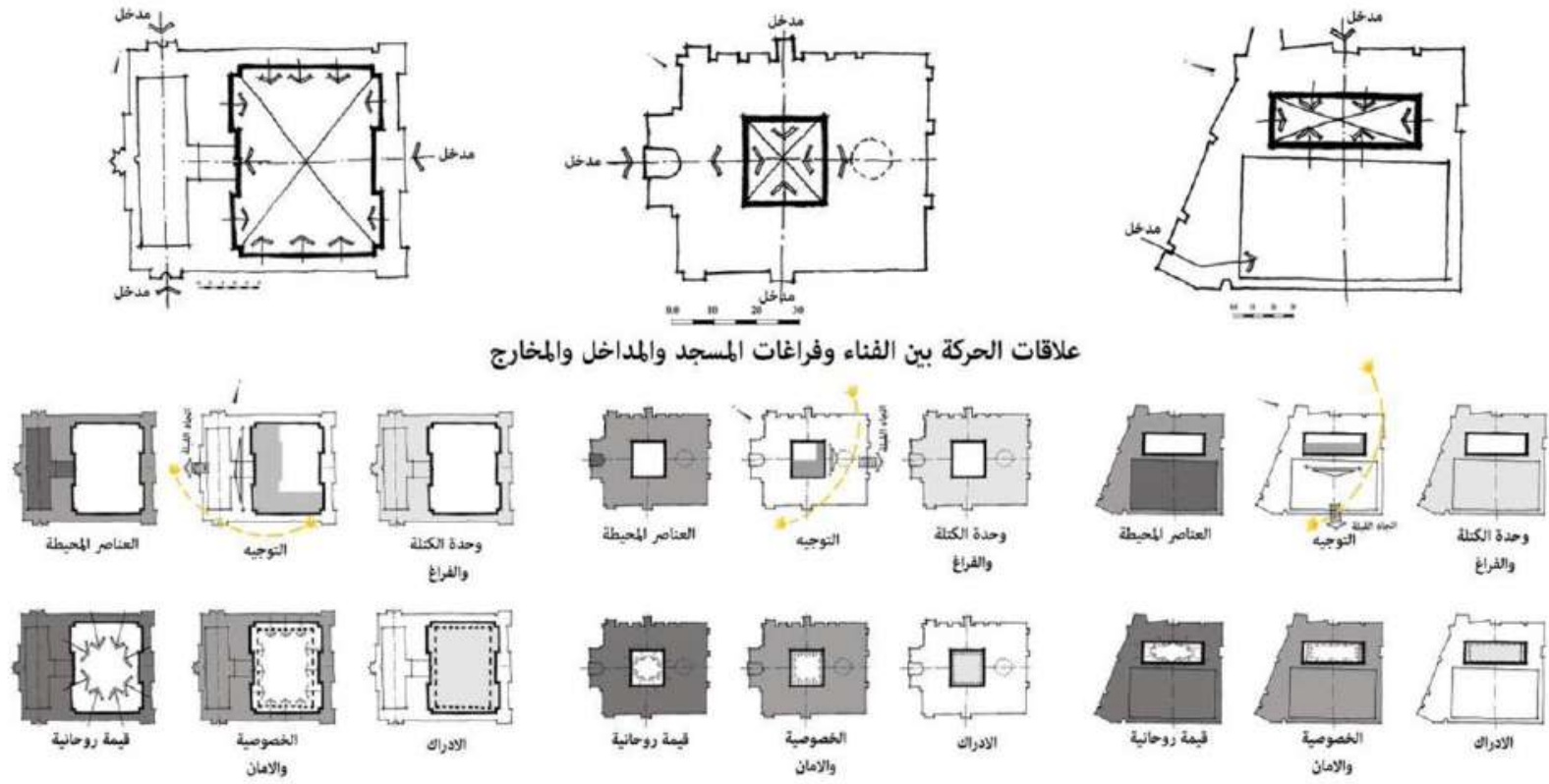

مسجد الثيخ زايد

مسجد الزهراء، القاهرة، مصر
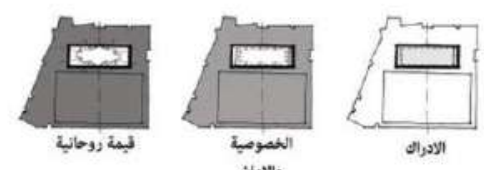

شكل ه r. المفاهيم التصميمية للفناء لمساجد حديثة متنوعة البيئات، الرياض، القاهرة، والإمارات العربية (الباحث). 

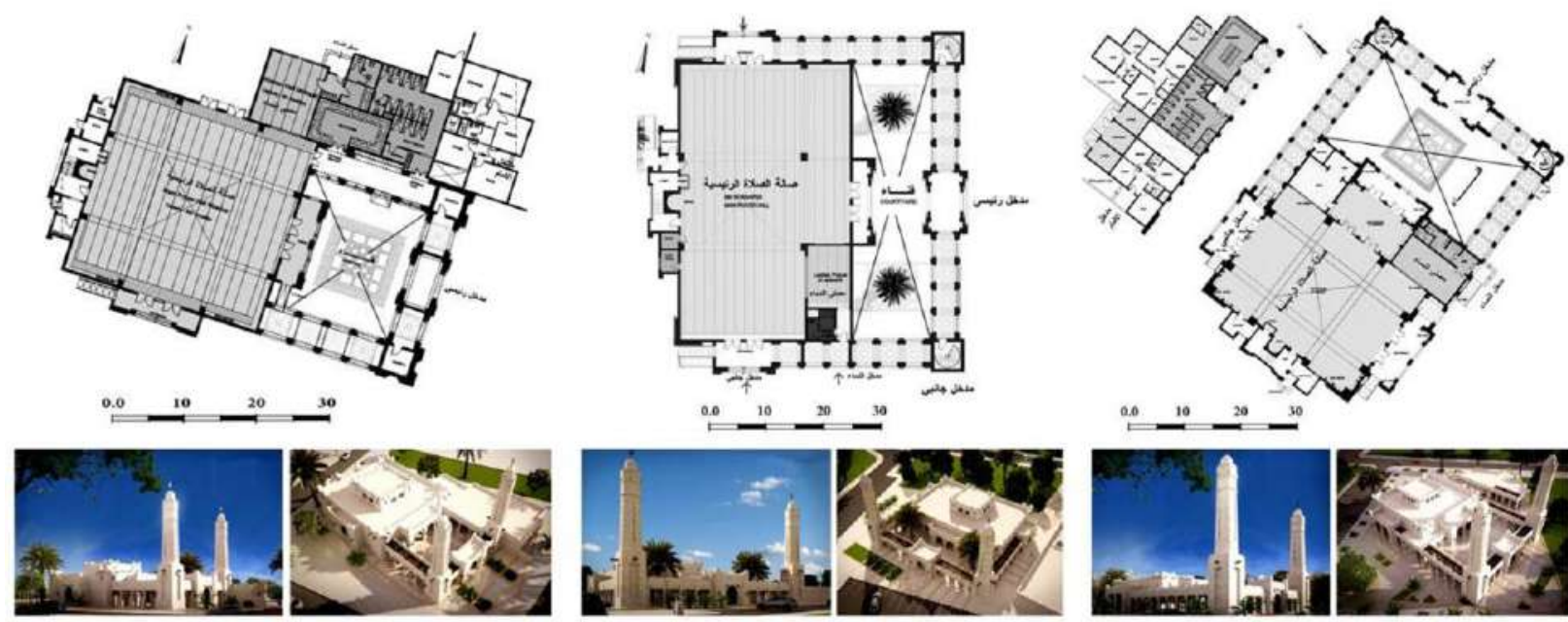

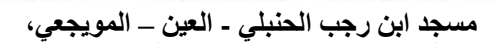

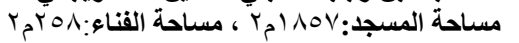

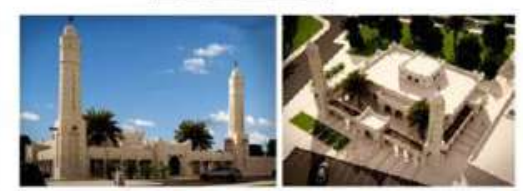

مسجد الاصلاح ـ العين - الفقع، مساحة ، ماحة

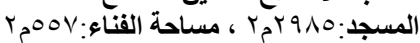

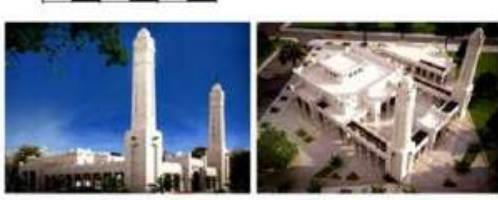

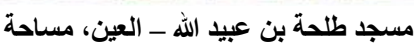

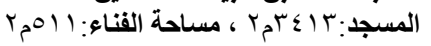

شكل 7 Y. أمثلة لمساجد حديثة بالعين - الإمارات.
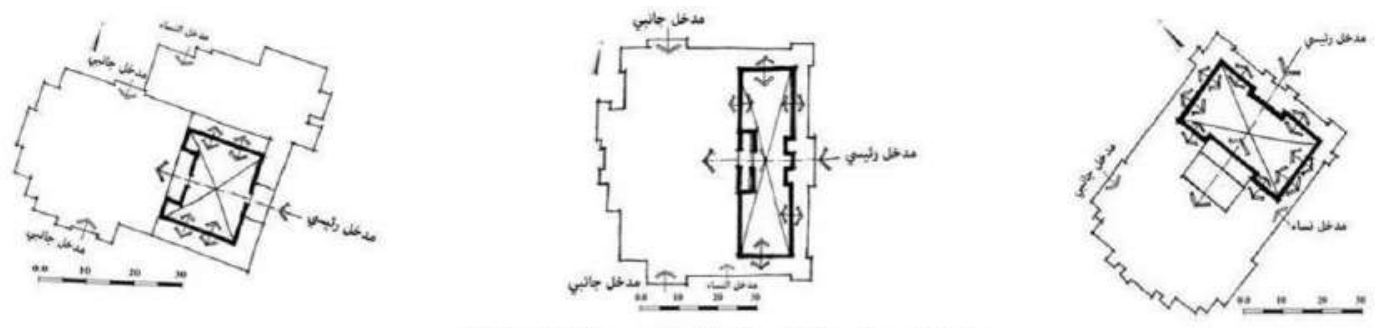

علاقات الحركة بين الفناء وفراغات الهسجد والهداخل والهخارج

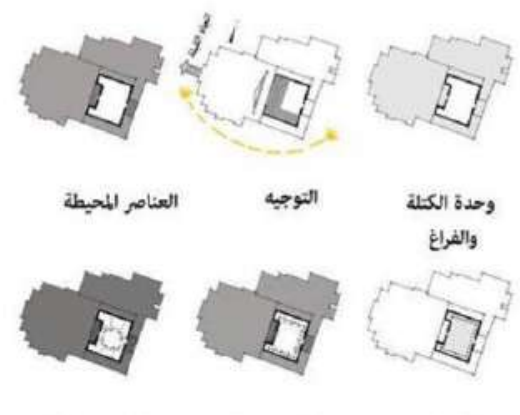

قيمة روحانية

الخصومية

الادراك

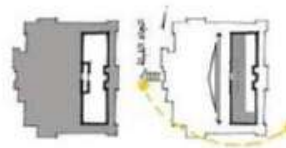

العناهر المحيطة

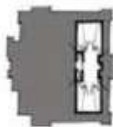

تبمة روحانية
التوجيه

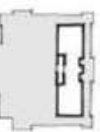

وحدة الكتلة والفراغ

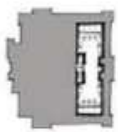

الخصومية

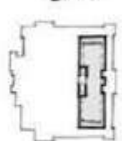

الادراك

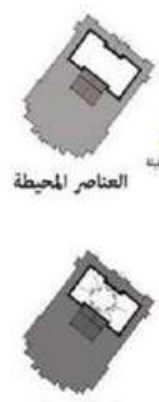

قيمة روحائية

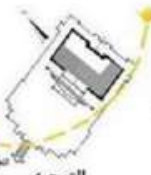

الثوجه

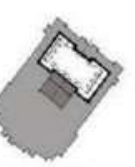

الخصوصية

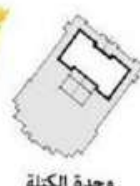

والفراغ

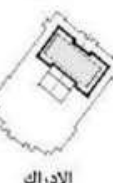

شكل rV . المفاهيم التصميمية للقناء لمساجد حديثة بالعين ـ الإمارات (الباحث).

ومعالجتها][־َ] إن العوامل البيئية والمناخية تعود إلى

- 1 العوامل البيئية والمناخية

مفـاهيم التصـميم المنـاخي في تلك المنـاطق والتي يمكن ايجازهـا في نقطتين رئيسـين، الأولـى هـي الحماية من المناخ، والثانية هي محاولة إيجاد طقس
تمثنل اثـكالية منــاخ اقلـيم الصـحاري الحـارة الجافـة الذي يعتبـر العمـود الفقري للعـالم الإسـلامي

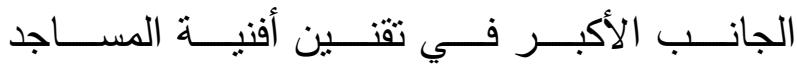


ويحقق الفنـاء تكـاملاً مـع المنظومــة الحراريـة وحركة الهواء، حيث يقوم الفناء لبلا بإعادة إثـعاع كميات الطاقة الثمسية التي اختزنها طوال النهار،

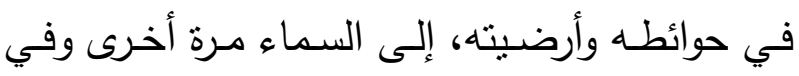
الوقت نفسه يتم تخزين الهواء البارد ليتت الاستفادة من برودة الفناء أثناء نهار اليوم التالي (شكل وج) [ [ 1]

أمسا أثناء النهار، فيختلف أداء الفناء الداخلي مع تعرضه للإشعاع الثمسي، فعندما يتعرض الفناء

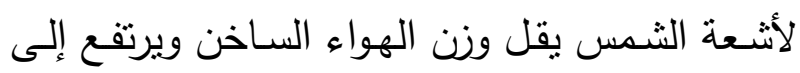

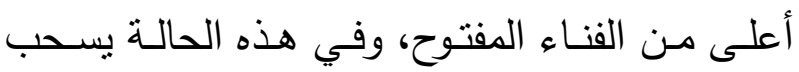
الهواء البارد من خلال الفراغات المغلقة ليحل محله

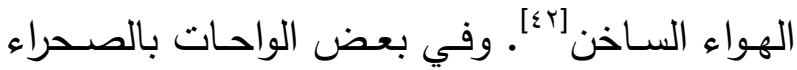
الجزائريـة تـم اسـتخلاه الاختـاف في درجـة الحـرارة للحصـول على توزيع جيد للهواء، كما هو موضـح

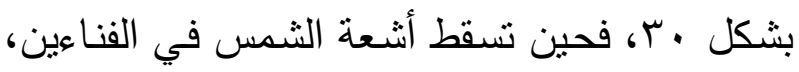

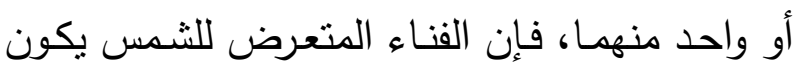
الهواء فيه أسخن من الفناء الآخر فيرتقع الهواء فيه إلى أعلى ويخرج خـارج المسجد، أمـا الهواء البارد فيسحب من الفناء الآخر ليحل محل الهواء الساخن الذي خرج، وبذلك يمر الهواء البارد خلال الفراغات.

وللعامـلـ المنــاخي دور فـي مفهـوم تصــميم

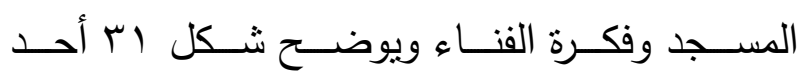
التوجهـات للاسـتفادة مـن التربـة فـي تتظيم حـرارة المسجد البناء المحمي بالتربة (Earth Shelter) ونقل
ملانُم لراحـة المستعملين، ففي فصل الثـتاء يكون

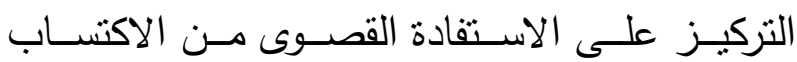
الحراري عن طريق الإشعاع الثمسي مع الإقلال من الن فقد الحرارة من المبني، وفي فصل الصيف يكون الاحتياج للتبريد فيراعى تصميم الفناء بأسلوب يعمل ولمبل

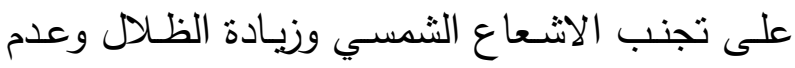
الاكتسـاب الحراري، مـع العمل على فقد الحرارة من

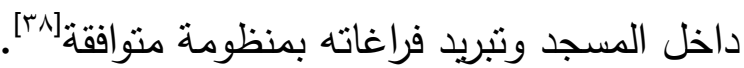

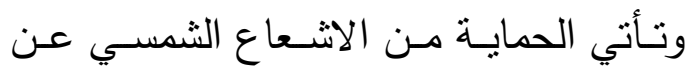

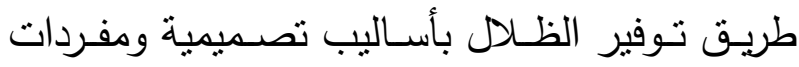

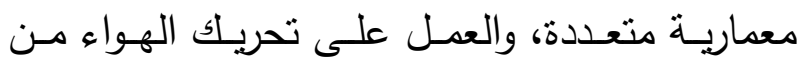
خلال التصميم المناسب، ولذلك تم اللجوء إلى الفناء وعناصره، والذي حقق مع المنظومة الفراغية للمسجد وكتلـه ومفرداتـه ومـواد بنائسه توافقـا لتحقيـق التـوازن

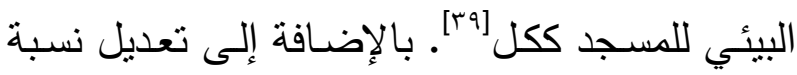
الرطوبة في الجو بزيادتها في المناطق القاسية الجافة

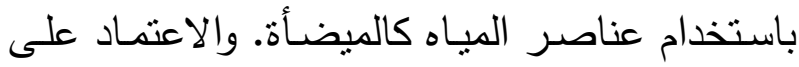
الاضــاءة الطبيعيـة مـن خـلال الفنـاء وعـلاج ظـاهرة الإبهار مـن خـله اسـتعمال معالجـات لـــواد البنـاء والأرضـيات واسـتخدام المشـربيات والفتحـات الضـيقة المطلة على الفناء.

وقد وعـي المصـمم للمسـاجد التراثيـة بأهميـة الفناء كمصدر أساسي للإضـاءة الطبيعية والتهويـة،

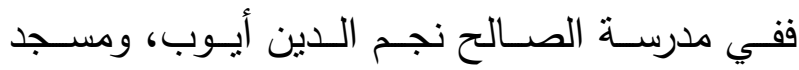
ومدرسـة السـلطان حسـن بمصـر نجـد أن الاعتمــاد

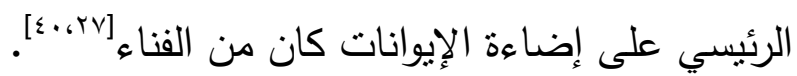


الإنسـاني"، "ويسـتمر الجـل فيمـا يتصـل بالعهـارة

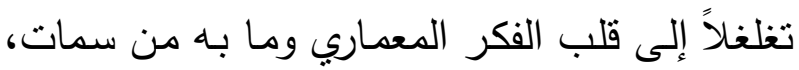
فـلا يتوقف البحث عـن علاقـة العمـارة بغيرهـا مـن

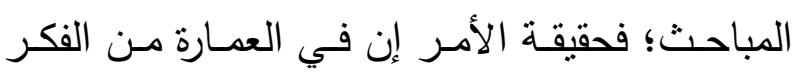

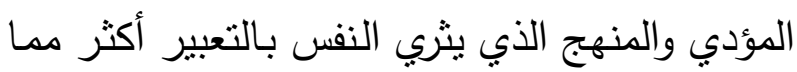

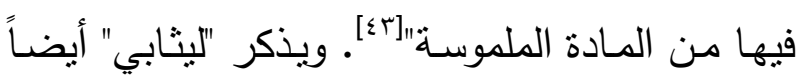

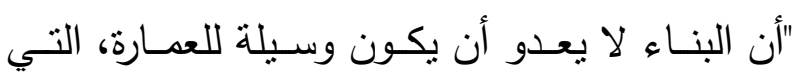

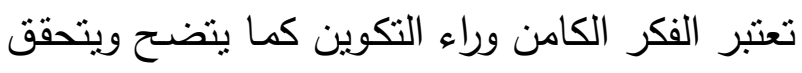
هدف التعبير ونقل المضمون. وهكذا يتخلل العمارة البنـاء لمـا هـو ابعـد مـن إرضـاء الحاجـات الماديـة البسيطة الى ارضاء حوائج الفكر"، وهكذا فبالرغم من إهن

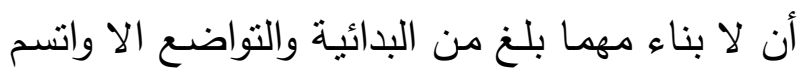

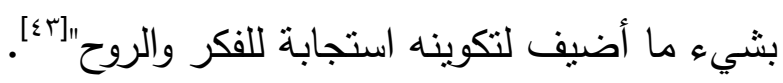
ويحقق بنـاء الفناء وعمارته مـا هو أبعد من المادية إلى المعنوية، حيث أن اتصال الفناء المباشر ونماء لهن

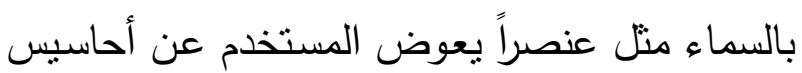

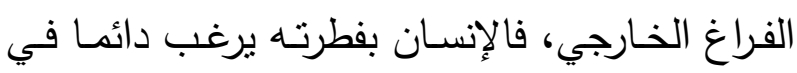

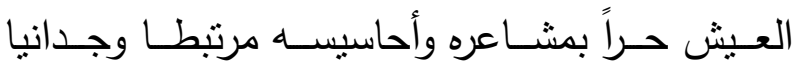
بالسماء، وخاصـة في أمساكن العبادة، وفي تكوين

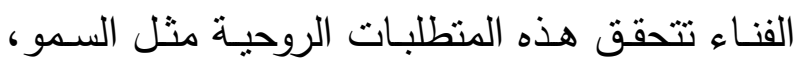

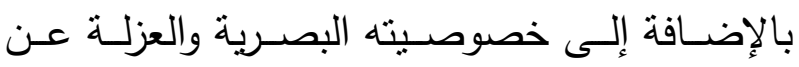
الأنشطة العامـة الخارجيـة. ويمثنل المسـد للإنسـان المسلم المركز الروحي والثقافي، فكان الاحتياج للفناء

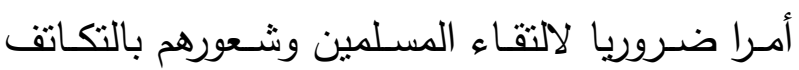
والترابط وممارسـة أنشطتهم الاجتماعيـة والجماعيـة. وفيه كان يلتقى الحاكم أو الوالي بالرعية [؛؛]
الفناء أعلى المسجد في محاولة للتحكم في المنظومة

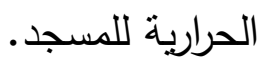

يوضــح شـكل r ب إمكانيـة التظليـل وتحريـك

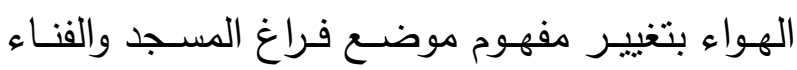
ومرونة دراسة مواضعه بالقطاع المعماري.

ويعمل الفناء علي تتظيم الحرارة بين المناخ العـام الخـارجي والمنـاخ الخـاص الـداخلي (المنــاخ

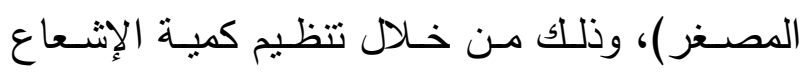
الثمسي الواصل إلى فراغه بالتوجيه وحساب نسب

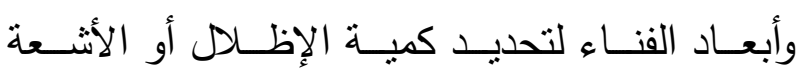
الواصلة اليه، وبالتالي التحكم في درجات الحرارة كما

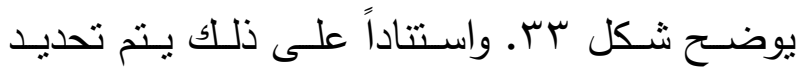

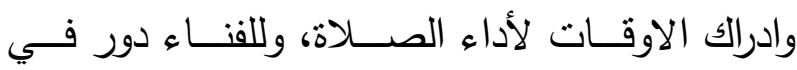
تأمين الحمايـة مـن الرمـال والغبـار وتتظيم حركـة

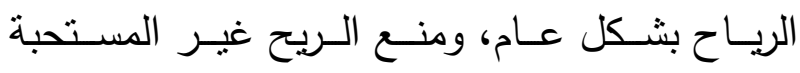
وخاصة في المناطق الصحراوية، كما استخدم الفناء

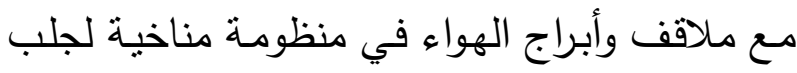
الهواء المستحب وتوجيهها، كما هو مطبق بمسـد الرحمانية بمنطقة الجوف بالمملكة العربية السعودية (شكل عاب). r-v يقـول "ليثـابي" في كتابـه العمـارة والأسـطورة والروحانيات، "إن العلاقة بين العمارة والفلسفة جدلية،

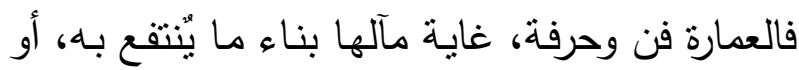
مـا يتـيح للنـاس تكـريس حيـز للمعـاش والفكـر 
المسـاجد بشـكل خـاص ونختص هنـا فراغ الفنـاء لمـا يتطلبه من مساحة ذات سمات خاصـة يصعب تكرارها في المبـاني المكونـة للنسيج العمراني. ويوضـح شكل هب العلاقة بين فناء المسجد والعمـران التراثي، فنجد التباين البصري الواضـح بين الفراغات الخارجية وفناء المسجد بالعدران التراثي، وبعبر "بنفلو" عن هذا التباين بقولـه" فـي مقابـل الاشـكال غيـر المنتظمـة للعمـران، تتبـاين اشكال افنيـة المسـاجد الواسـعة المنتظمـة، فأفنيـة المساجد التاريخيـة تعتبر أكبر فراغ عام داخل المدينة الإسلامية القديمة، مما أدى إلى إحساس غامر بالتباين الفراغي بين الفراغات الخارجية الضيقة غير المنتظمة المليئة بالحركـة والحيـاة وبـين فنـاء المسـجد المنـتظم الثكل البسيط المتسع"[0؛]

ويوضــح شـكل بم أنــه يغلـب على معظى الانمـاط التشـكيلية في العدـران الحـديث الانتظــام، لفي

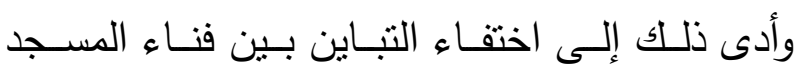
الحديث إن وجد مـع مـا يقابله من فراغات عمرانيـة، مـع عـدم الإحسـاس باتسـاع الفنـاء نسـبة للفراغـات

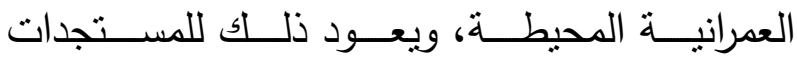
والمتغيرات الوظيفية والاجتماعية والمفاهيم المعمارية والنظم الإنشائية.

\section{- - موضع الفناء بإلنسبة للمسج}

لموضـع الفناء بالنسبة للمسجد عامل هام في علاقـات الحركـة واسـتعمال الفراغـات، ويـؤثز أيضـا بشكل فعال في الأداء المناخي للمسجد وعلاقة حركة الثــمس والظـلال والربــاح بالنسـبـة لموضـعهه واثـر v r العوامل الوظيفية

أشــارت الدراسـات إلـى عـدة وظـائف أخـرى

للمسـجد غير العبـادة، فقد كان مركزاً للتعليم وداراً

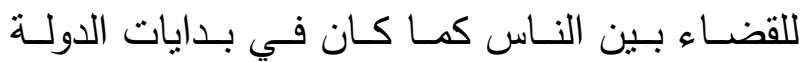
الإسـامية مقراً للحكم وادارة امسور المسـمين واتخـاذ القرارات السياسية، بالإضـافة الى ذلك كانت تمـارس فيه بعض الألعاب الرياضية. [1 ]. وقد شهد المسجد النبوي في بداية إنشائه الدليل الواضـــح للحاجـة الوظيفيـة للفنـاء، وتبعتــهـ المسـاجد الجامعـة المنتشـرة في أرجـاء العـالم الإسـالامي حيـث كانـت الحاجـة إلى وجـود فراغ خـارجي كامتداد للفراغ الداخلي والممثل في بداياته بصـالة الصـلاة، ويستعدل هذا الفراغ في الصـلاة في أوقات الأعداد الكبيرة أولاً، وللقاءات المهمة والدروس وللهروب من حرارة الفراغات الاخليـة إلى الفـراغ المفتوح الأعلى أداءً مـن الناحيـة المناخية. وقد تتوعت مساحة الفناء، ويعود ذلك بمقارنة مكان المسجد وأعداد مستعمليه أولاً، وثانياً كان الوالي ولي ولي أو الحاكم بلتقي بالرعية به في المناسبات فكان لابد أن يتسـع الفناء لغالبية السكان بالإضـافة إلى رجال الدولة

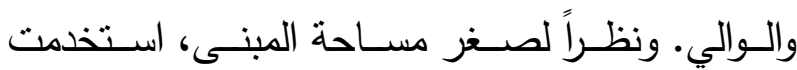
الأفنية الخارجية لتعويض المساحة، وذلك يفسر خروج الفناء خارج كتلة المسجد بالعمارة العثمانية.

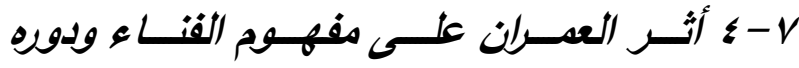
بالمساجد التراثية والمعاصرة

أثر المحتوى العمرانـي المحبط على الفراغـات ونوعيتهـا داخـل الأبنــة بشـكل عـام، وعلى فراغـات 
قـدمت التكنولوجيـا مـن الحـــول التـي تتســم

بالاسـتدامة في معالجـة الفراغـات المفتوحـة والأفنيـة كما يوضـح شكل 9 ؟، وهي حلول معاصرة لتطويع مفاهيم استغلال الطاقة الثمسية لعمل انظمة النظليل الذكية والتي تتصف بالمرونة تبعا لمعطيات الطقس

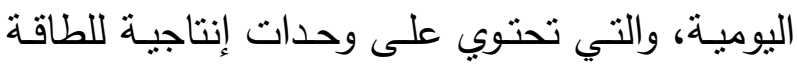
لدم استهلالك البناء واستدامته. يوضح شكل • ؛ خلاصـة العوامل التي أثرت

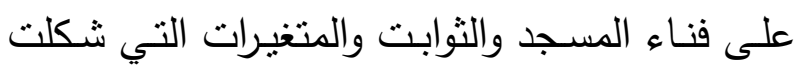
وصاغت مفاهيم تكوينه من التراث إلى المعاصرة.

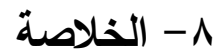

مـن خـله الدراســة السـابقة للفنـاء بالمسـاجد التراثيــة والمعاصـرة يمكن ايجـاز خلاصــة المفــاهيم

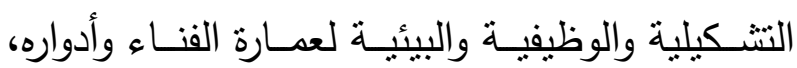
وإبراز أهم التوجهات لمعاصرة استخدامه في الآتي:

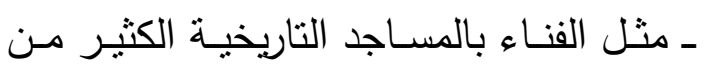

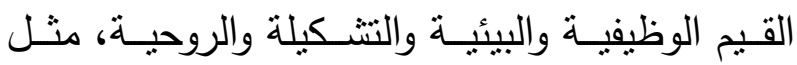
الاتصـال الروحي مـع السماء والإحسـاس بالاحتيـاج للفراغ المفتوح، بالإضـافة إلى أدواره المتعددة، فقد الإحس استعمل الفناء بصفة مستمرة كامتداد خارجي لصالة الصلاة في وقت الحاجة، وعند تحسن الطقس كانت تقـام فيـهـ بعـض الصــلوات. وبالإضــافة إلـى دوره الوظيفي، فقد حقق الخصوصية السمعية والبصرية بجانــب تحقيقـــه للنــواحي الاجتماعيــة باســتيعابه للتجمعات واللقاءات والانشطة المجتمعية.
الفراغات والمفردات المحيطة بذلك الموضع، ويمثل الموضع اشكالية مهمة في العمران الحديث، ويتطلب

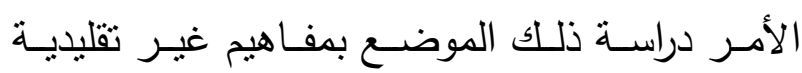

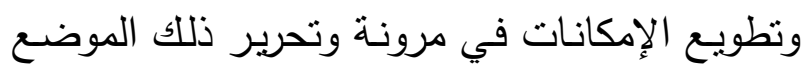
بمـا يناسب العلاقـات الوظيفيـة والروحيـة والمناخيـة بينه وبين فراغات المسجد.

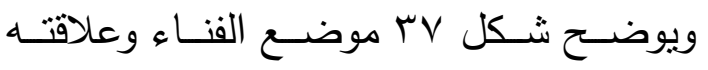
بفراغـات المسـد في المسـاجد التراثيـة، والذي جـاء مستجيبا للمتطلبات البيئية والوظيفية والاجتماعية. في محساولات لعمل معالجـات للفنـاء ببعض

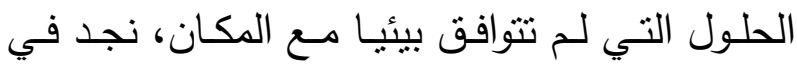

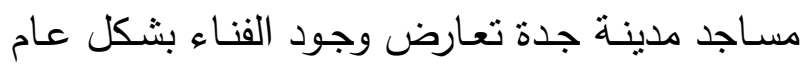
مع الأبنية وقد اختفى الفناء في مباني جدة التاريخية

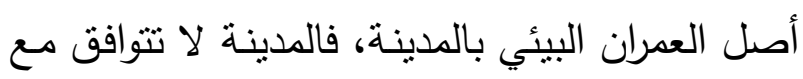
استعمال الأنشطة بالفراغات المفتوحة، ويحتاج الأمر بالهر

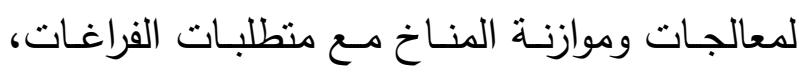
فنسبة الرطوبة تحول دون استعمال الأفنية. ويوضح

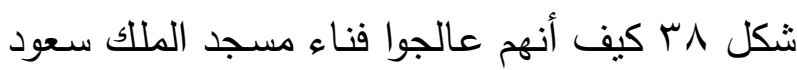
بتغطية الفناء ليكون جزءا من المسجد كفراغ داخلي ولتخفيف أثز المناخ الخارجي على فراغات المسجد.

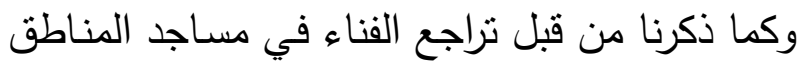

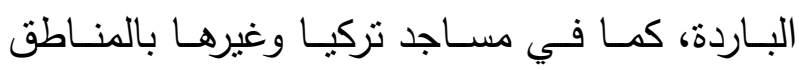

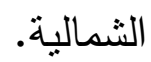




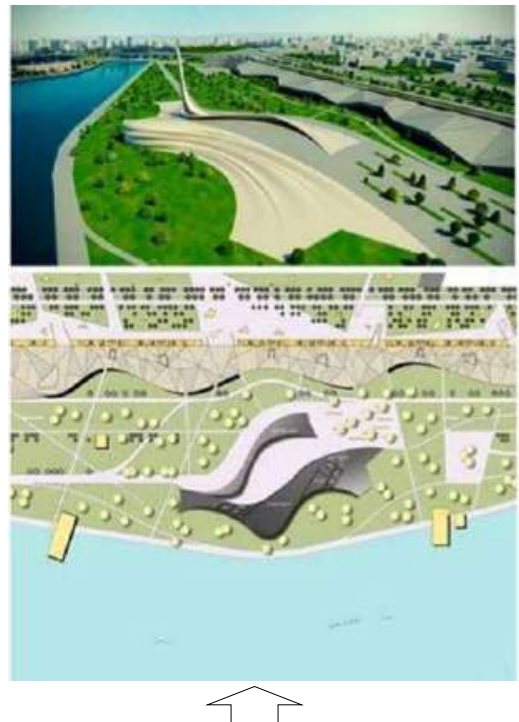

المسجد من تصميم المهندس Emrah) Cetinkaya) وتبلورت الفكرة التصميمية حول معاصرة المفردات، وكان المبدأ انه لا حاجة لبعض حلئ المفردات التي استمرت فترات طويلة ولا تمثل في الوقت الحاضر أب قيمة وظيفية مع الاحتفاظ بالقيمة الرمزية لها، فيمكن للإمكانات المعاصرة الاستغناء عن بعضها أو تحويرها،

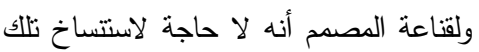
المفردات حيث يمكن عمل سقف يغطي بحورا كبيرة دون قباب او اعمدة كثبرة، كذلك المئذنة التي كانت ضرورية لسماع الآذان في حين ان التقنيات المعاصرة يمكن الاستغناء عنها، واحتفظ المصمم بالمئذنة بشكل عصري لكي

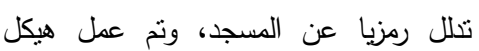
المسجد من قشرة انسيابية بليلا عن القبة، لهن ويأني الفناء في صورة تؤكد مفهوم انفصال الفناء عن بناء المسجد كاستمرارية لمفهوم تصميم المساجد التركية منل مسجد السليمانية. وامتد الفناء في انسيابية واستمرارية حول المسجد ليصعد أعلى بناء المسجد محقق وأنق لمفهوم السمو [ن؟؛]

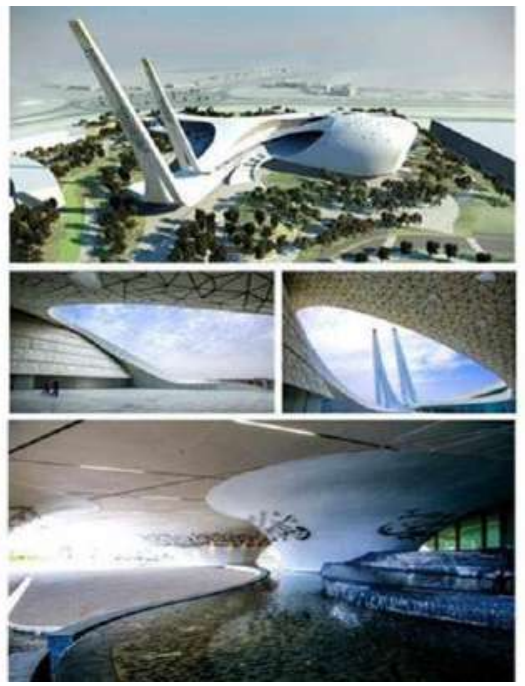

$\checkmark$

مسجد المدينة التعليمية بالدوحة، من

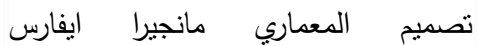
(Mangera Yvars) المدخل الرئيس لحرم المدينة، صمم المسجد

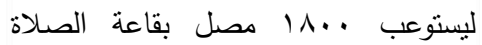
والفناء الخارجي معا، تم تصميم المسجد مرنكزا على خمسة أعمدة رئيسية في اشثارة رمزية لأركان الإسلام الخمسة، في محاولة

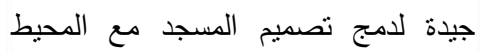
الخارجي صممت اربعة قنوات مائية تتساب وتعانق المسجد مع الفراغ الخارجي لتمثل رزيا أنهار الجنة، النبيذ والحليب والعسل العل والماء. اندمج الفناء منسابا من فراغات المسجد وعناصره وكانه يخرج سابحا من المسجد إلى الفراغ الخارجي ومستمرا في انسيابه وسمو مدركاً مآذن المسجد التي تبدو وكأنها تتسابق في التوجه الى مكة بالدعاء.

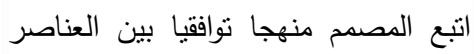
المادية والرمزية["]؛
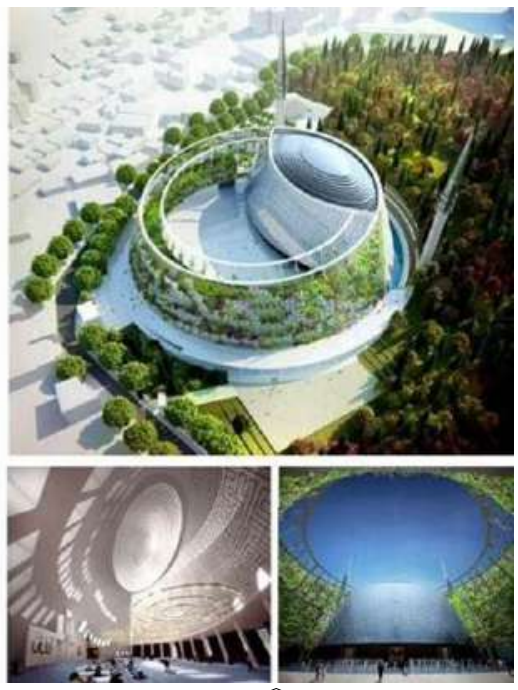

$\Upsilon 2$

هو أحد اقتراحات مسابقة تصميم مسجد

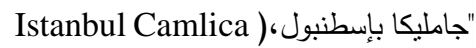
Mosque

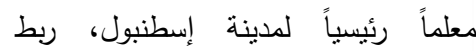
المصمم مفهوم الفناء كامتداد مع الطبيعة المحيطة بالمسجد الذي يقع على قمة تل إسطنبول، فقد احاط الفناء بحائط له درجة بله من الثفافية للتواصل مع الطبيعة المحيطة، وليفتح المجال للمستعمل لربط الحيز المحدود بالحيز اللامحدود، تحتوي جدران الفناء على النباتات من الورود

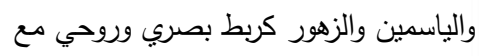
منطقة "جنة عدن" على قمة التل في اشارة رمزية للآخرة، ويتسم حائط الفناء بدرجة من الخصوصية وصمم لهدف وظيفي لاستيعاب تجمع المسلمون للصداة والتعلم والأنشطة الاجنماعية الأخرى[ــ] 


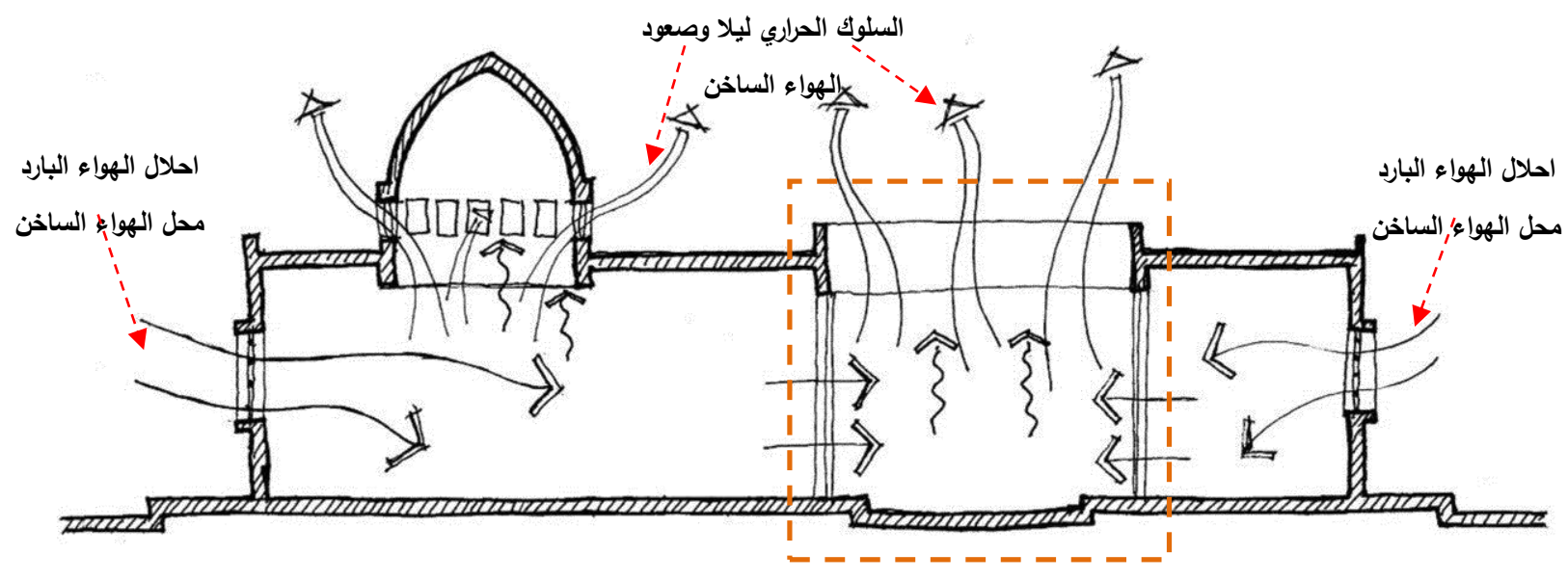

شكل ج ب. كفاءة الفناء في عمل مناخ مصغز يوفر الراحة الحرارية للمسجد، ويبين الثكل الأداء الحراري للفناء

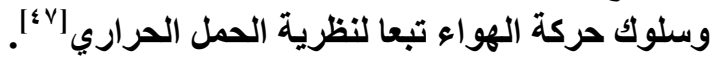

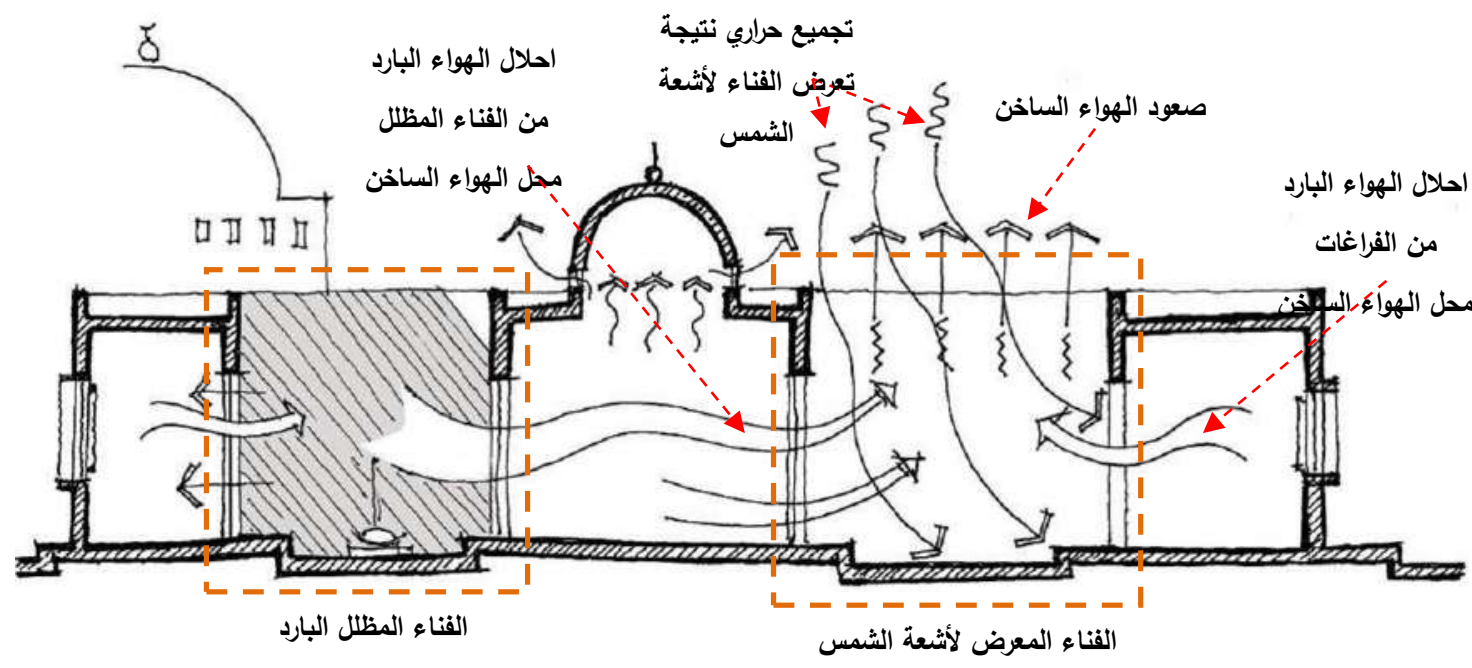

شكل • r. يعمل وجود أكثر من فناء على تفعيل منظومة هوائية وانسياب الهواء من الفناء البارد للقناء الساخن

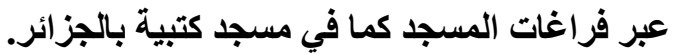




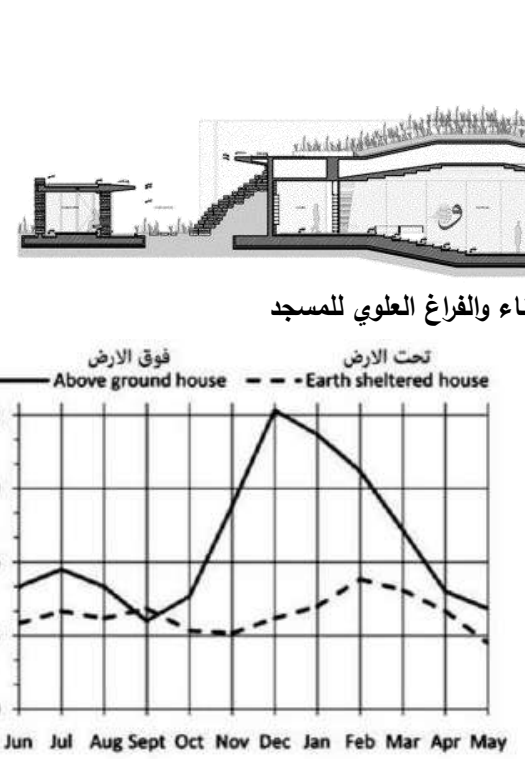

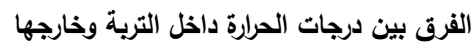

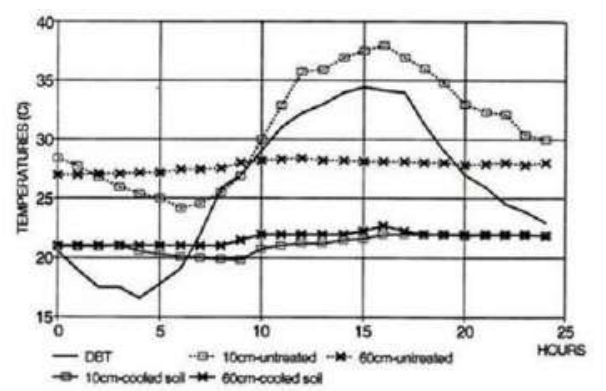

الفرق في الثبات الحراري وعامل عمق التربة مع الزمن
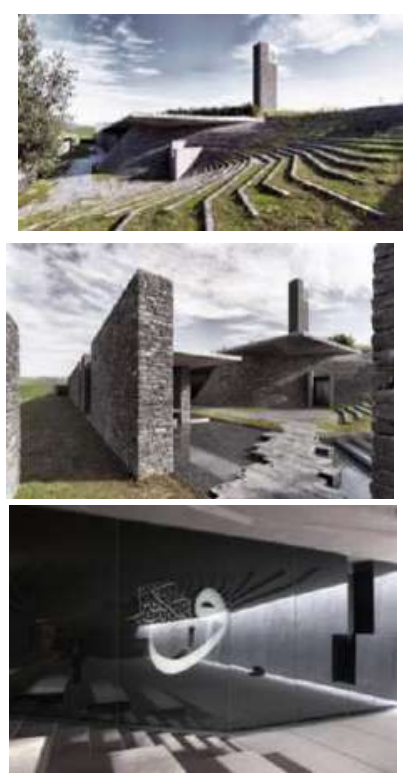

شكل المسجد من الخارج والداخل

شكل اس. مسجد سانكاكلار، "Sancaklar " أحد التوجهات لتحسين المنظومة الحرارية للفراغات المعمارية،

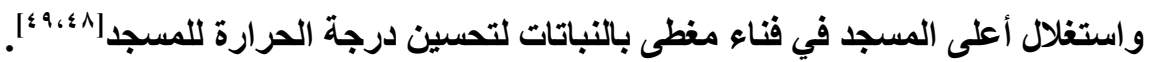

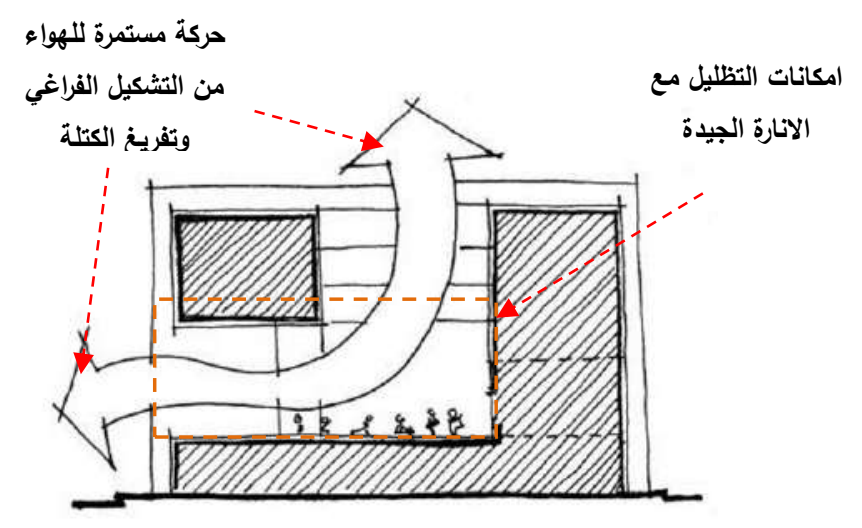

شكل r r. دراسة مرونة موضع الفناء مع المسجد في القطاع المعماري والامكانات المناخية المستفادة من التهوية والتظليل. 


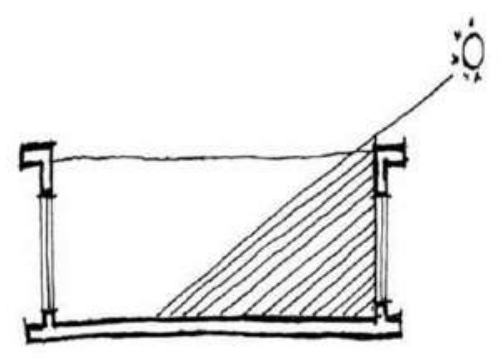

التحكم في كميات الظلال وتوجيهها لتخفيف درجة الحرارة أو التمتع بالتشميس في البلاد الباردة

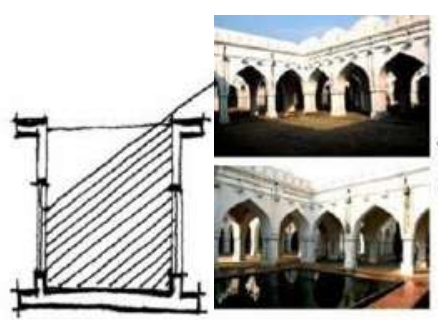

(مسجد كالان - نيوديلهي)، التظليل قاد فكرة تقبيم الفناء لأربعة أجزاء لتوفير

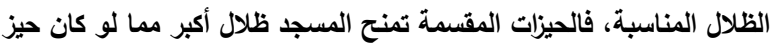

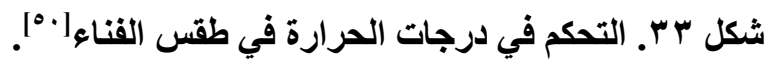

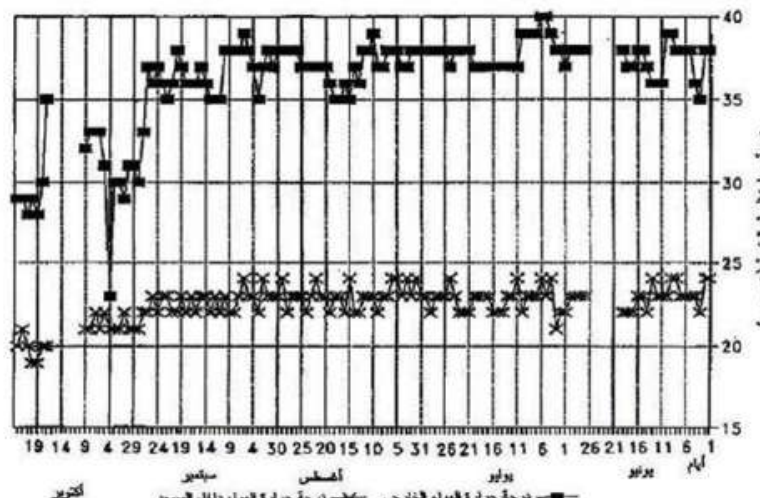

-

درجات الحرارة داخل وخارج مسجد الرحمانية

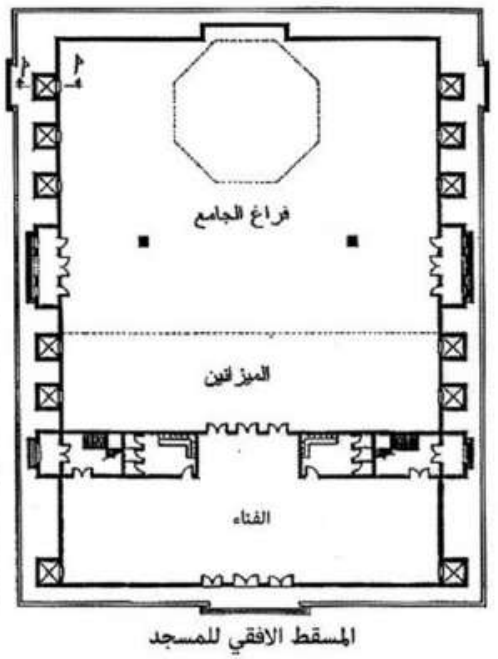

شكل ع م. مسجد الرحمانية بمنطقة الجوف. دراسة تحليلية أجريت على مفهوم استخدام ملاقف الهو اء بالمسجد و الفناء

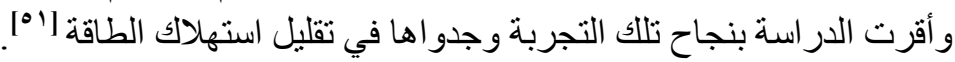




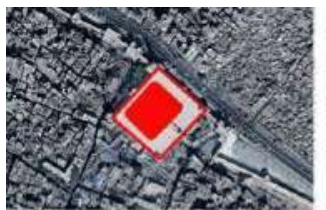

مسجد الحاكم بالقاهرة

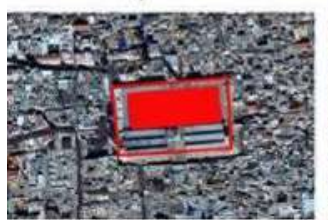

المسجد الاموي بسوريا

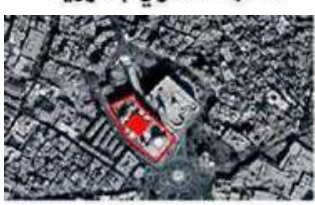

مسجد السلطان حسن بالقاهرة

2.7.

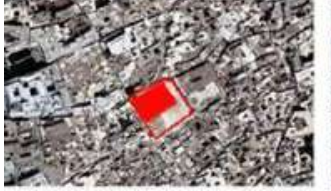

مسجد الزيتونة بتونس

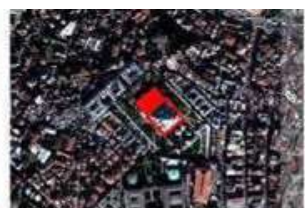

مسجد السليمانية بتركيا

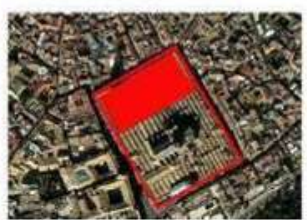

مسجد قرطبة باسبانيا

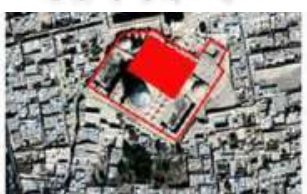

مسجد الشاه عباس باصفهان

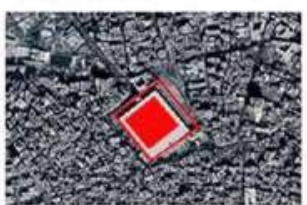

مسجد ابن طولون بالقاهرة

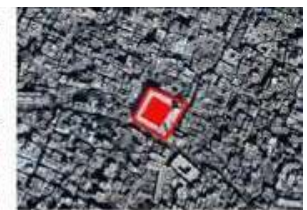

مسجد المؤيد بالقاهرة

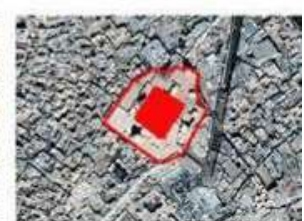

مسجد الجمعة باصفهان

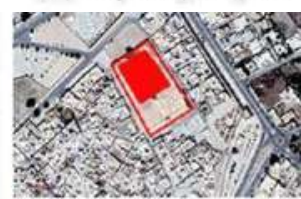

مسجد القيروان بتونس

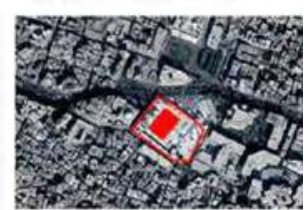

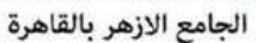

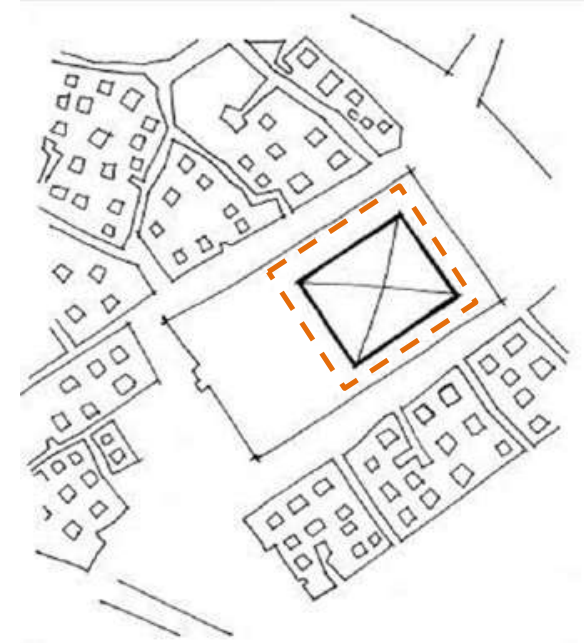

شكل هr. علاقة الفناء بالنسيج العمراني

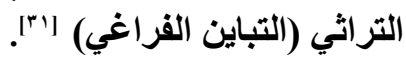

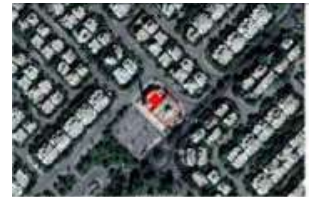

مسجد المرحلة الاوله - الرحاب

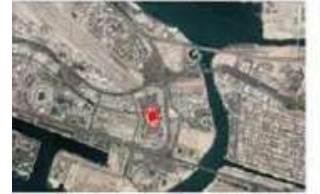

مسجد الشيخ زايد- الامارات

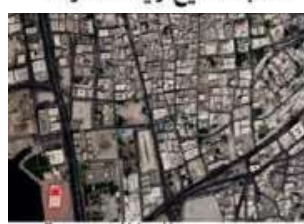

مسجد الجفالي - جدة

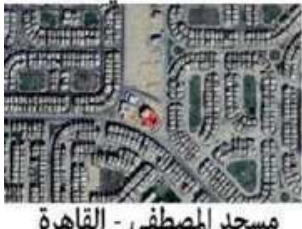

مسحد المصطفى - القاهرة

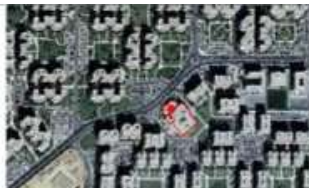

مسجد عثهان بن عفان - الرحاب

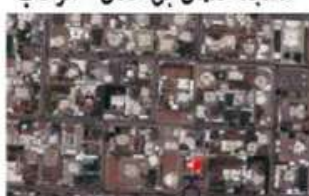

مسجد بالعين - الامارات

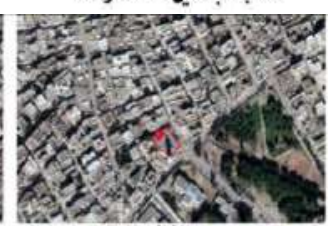

مسجد بلال - تونس

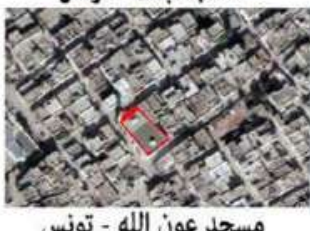

مسجد عون الله - تونس

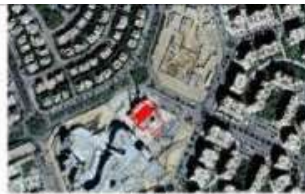

مسجد عمر بن الخطاب - الرحاب

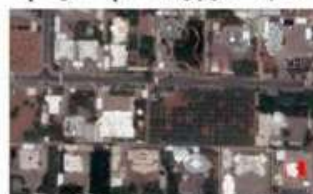

مسجد بالعين - الامارات

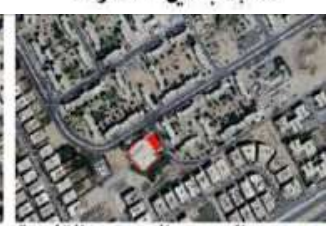
مسحد الرحمز الرحم - القاهرة

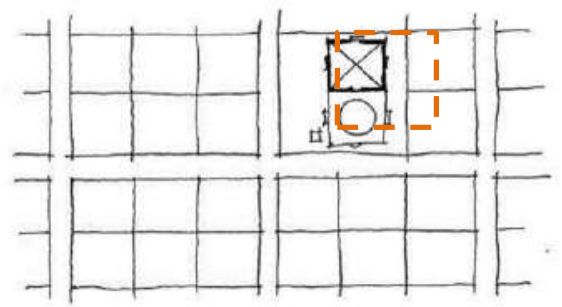

شكل بس. علاقة الفناء بالنسيج العمراني

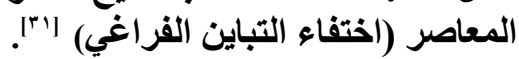




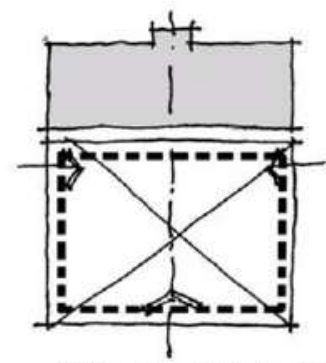

الفئاء جنوب الثراق، روات جهة القيلة

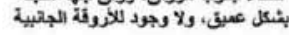
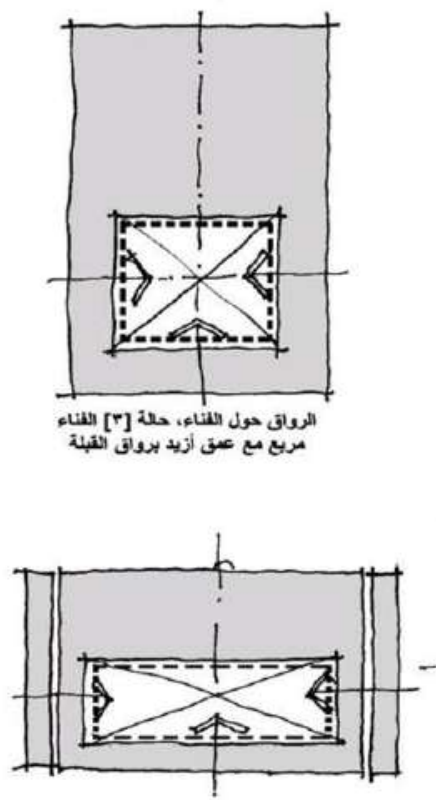

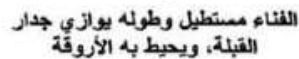

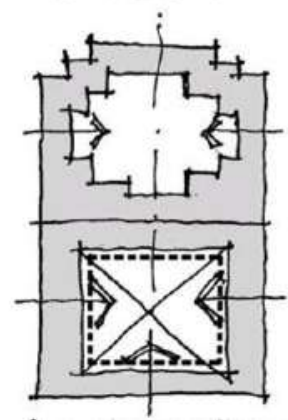

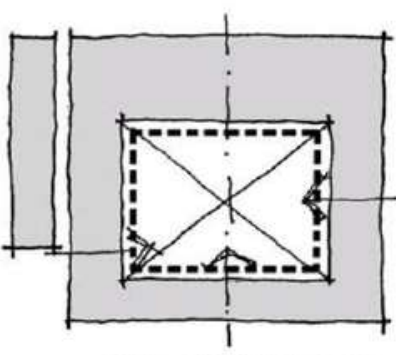

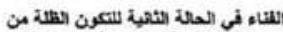

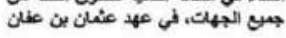
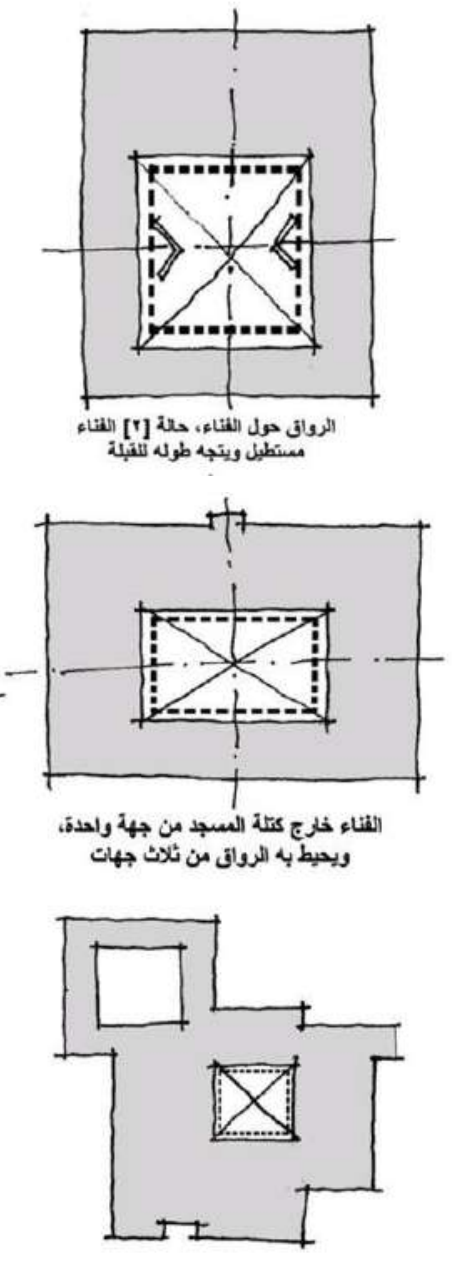

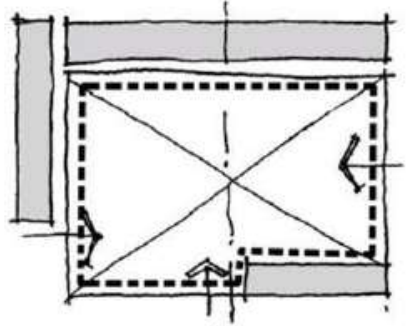

الثناء في الحالة الأولى للتكون الطلة من

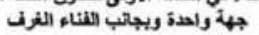
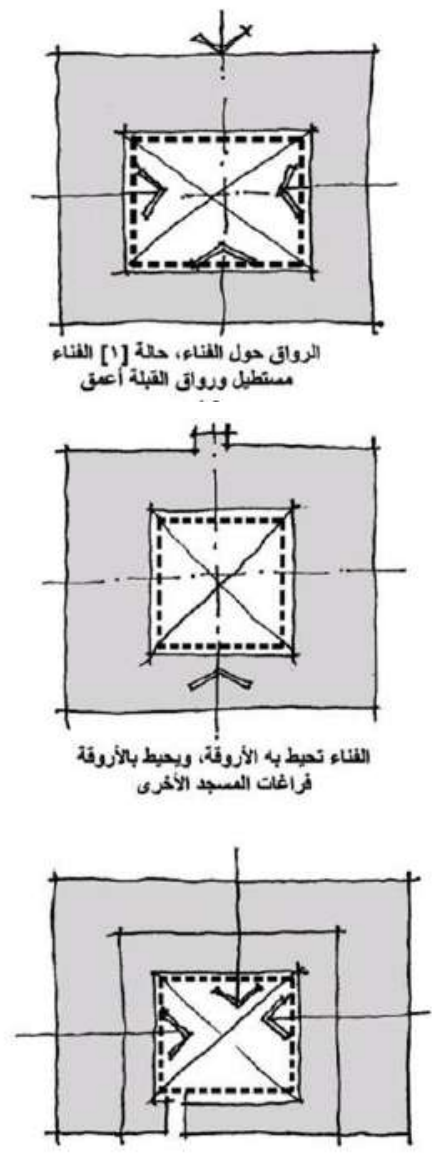

شكل VV . موضع الفناء و علاقته بفراغات المسجد. 

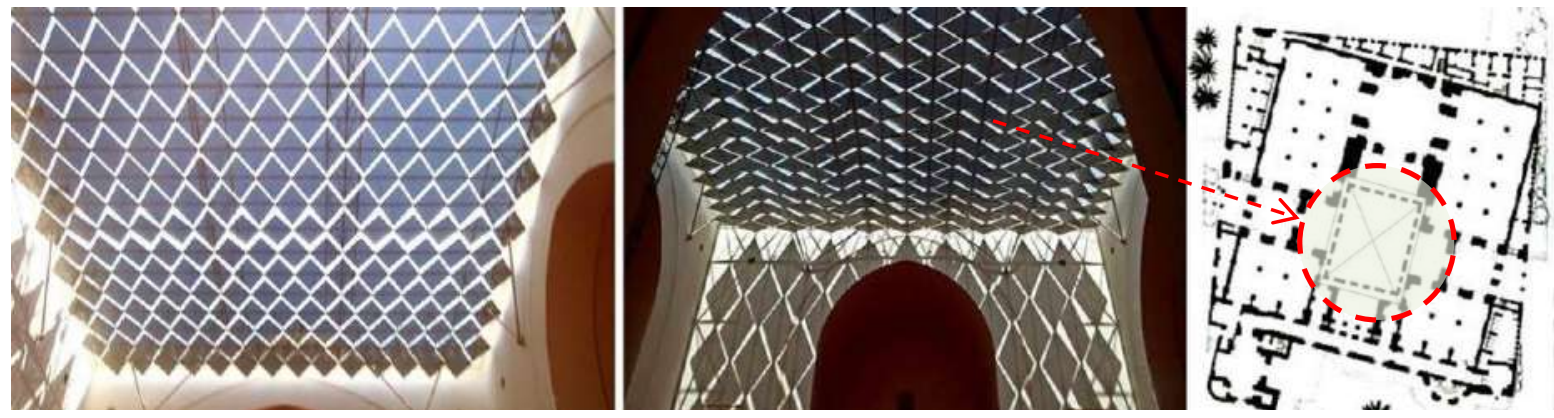

شكل ^^ـ. معالجة سقف فناء مسجد الملك سعود لكي يتوافق مناخيا مع المكان.
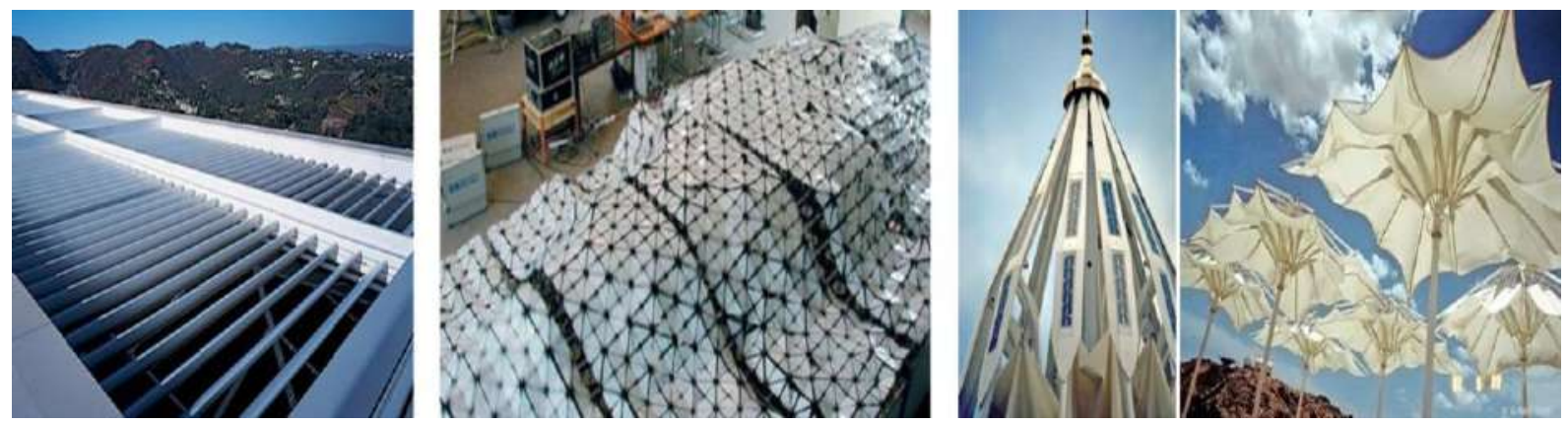

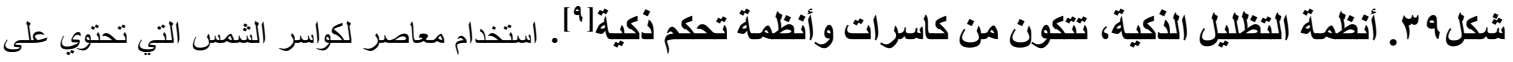
الخلايا الثمسية الكهروضوئية لإنتاج الطاقة.

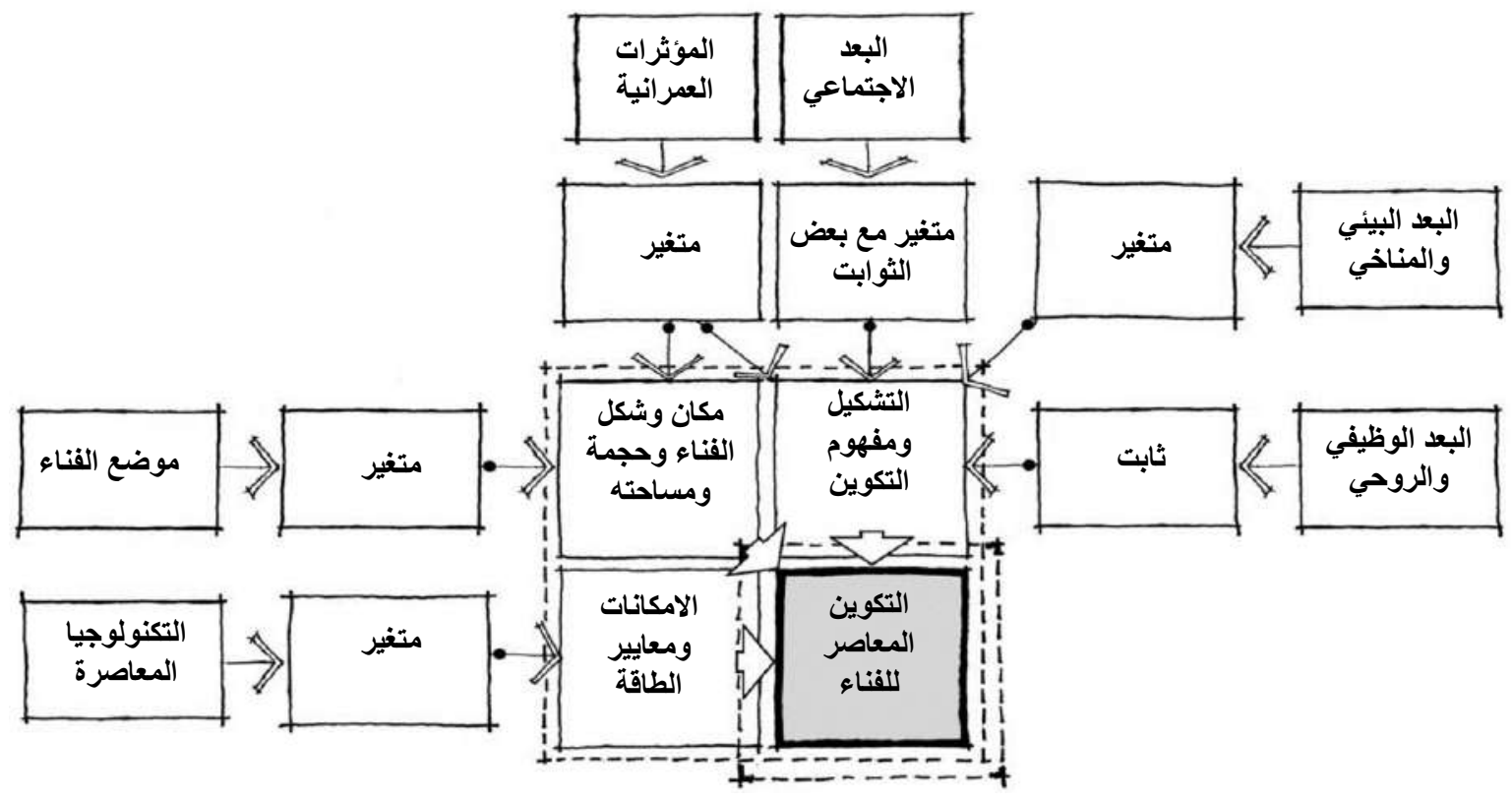

شكل • ؛ـ. الثوابت والمتغيرات التي تؤثر على مفاهيم وأدوار الفناء بالمسجد المعاصر. 
الأفنية في بعض الأماكن حتى أصبح لأحد المساجد ثلاثة أفنبة.

- حدثت تحولات للفناء، وفي غالبية المساجد العثمانيـة وضـع خـارج حدود كتلة المسـد، وسُققت المساحة الدخصصة الداخلية البديلة بالقباب والأقبية وأنصـاف القبـاب في بعض الأحيـان. واسـتبدلت

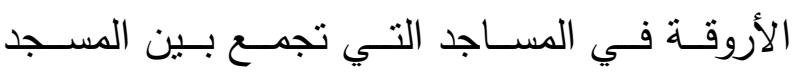

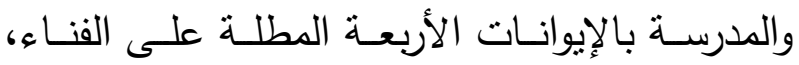

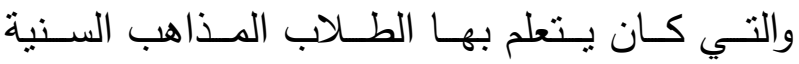
الأربعة، واختفي عنصر الفناء في بعض المناطق لحاجة بيئية وعمرانية.

- بينت الأمنتة المعاصرة التي تواجد بها الفناء، اتجاهـات منباينـة فمنهـا مـن اسـتفادت مـن المفـاهيم والمفردات التراثيـة، ومنهـا مـا استعمل الفنـاء كعنصـر يمنح المسجد رمزاً منوارثا، وافتقدت في غالبيتها التكامل والتوافق بين معطيات العصر والتكنولوجيا والمنطلبات

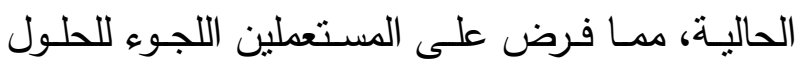
العلاجية للتوافق مع البيئة.

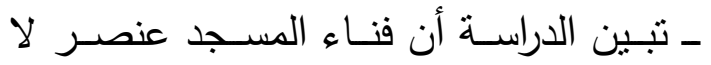
يمكن الاستغناء عنـه، فالقيم الثابتة كان لها الدور

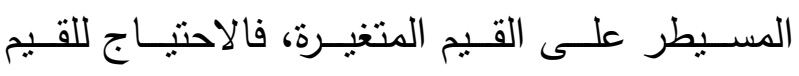
الروحانية والاتصال بالفراغ الأعظم، والتمسك بالدين

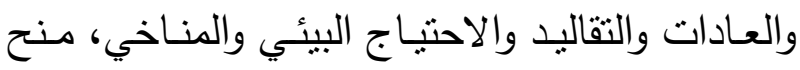
المصمم والمستعمل البحث عن حلول غير تقليدية

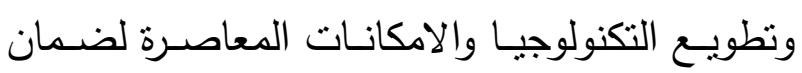

- بيئياً نظم الفنـاء الجانب المنـاخي للمسـد من حيث درجات الحرارة وحركة الهواء، وشكل الفناء المنـاخ المصـغر المناسـب الــي رفـع الأداء البيئي للمسجد من حيث المناخ ومفرداته (هواء - حرارة ظلال - تشميس - ترطيب) وتتظيم الإضـاءة. وزاد هذا الجانب قيمـة بعد ظهور فراغات مغلقة بجانب

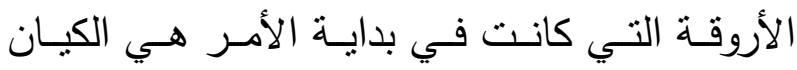

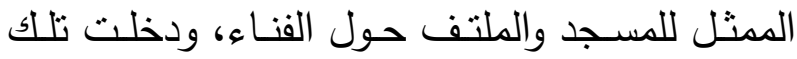
الفراغـات مـع الفنـاء في منظومـة التوازن الحـراري، وتحسن التبريد العام للمسجد، وعمل الفناء مع حركة لهنة الهواء من وإلى الفراغات المغلقة على رفع الكفاءة المناخية للمسجد ككل. - يؤثر موضـع الفناء بشكل فعـال في تحقيق المتطلبات الوظيفية والمناخية والاجتماعية للمسجد، ومن الناحيـة المناخيـة يفضل وجود فنـاعين، ويوجـهـ موضعهما وسـلوكهما الحراري والمعالجـة بـالمفردات بحيث يكون هناك اختلاف بينهما، مما يجعل هناك حركة مستمرة للهواء بين الفناء الساخن والفناء البارد، الأمر الذي يرفع قيمة الأداء الحراري للمسجد. ـ للمفـاهيم الوظيفيـة أثرهـا في شكل ومسـاحة الفناء التي غلب عليها الاستطالة، ورُصِدِت ظاهرة

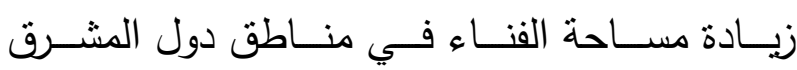

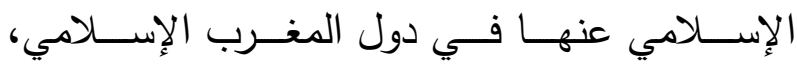

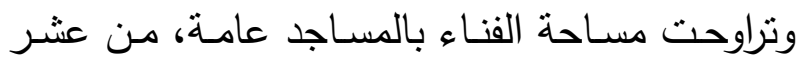
المساحة إلى تثلثي مسـاحة المسجد الكلية. وتعددت 
بجمهورية مصر العربية - لجنة إحياء التراث

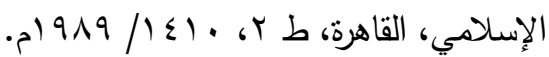
مؤنس، حسين (1919 (م)، المساجد، عالم المعرفة، سلسلة كتب نقافية، المجلس الوطني للتقافة والفنون والآداب، الكويت، العدد Vr، يناير.

الناجم، علي عثمان والمفيز، إبراهيم عبدالله،

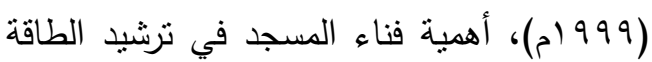

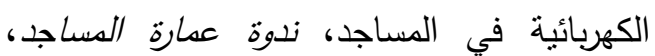

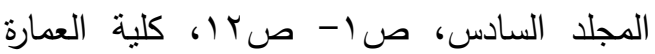
والتخطيط، جامعة الملك سعود، الرياض. فكري، أحمد (اله (197)، مساجد القاهة ومدارسها

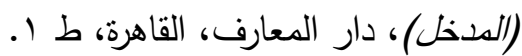
البلاذري، أبو العباس أحمد بن يحيى بن جابر(9^v (م)، فتوح البلدان، تحقيق عبد الله أنبيس الطباع، عمر أنيس الطباع،.

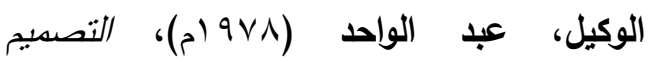

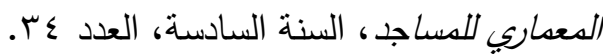

Frishman, Khan (2002), The Mosque: History, Architecture, development and regional diversity. 2nd ed. London: Thames and Hudson p32.

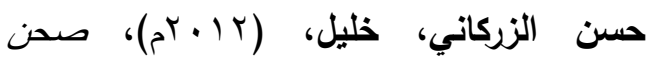
المسجد الجامع وتطوره في العدارة الإسلامية حتى

$$
\text { نهاية العصر العثاني. }
$$

Abuel Seoud, Radwa(2013), Reflection of Technology on the Inherited Conceptual Design of Mosques, A thesis submitted to the Faculty of Engineering - Ain Shams, University in partial fulfillment of the requirements for Master of Science Degree in Architecture.

$$
\begin{aligned}
& \text { إبراهيم، حسن (TVT (1)، تاريخ الإسلام السياسي } \\
& \text { والديني والثقافي والاجتماعي، مكتبة النهضة النها }
\end{aligned}
$$

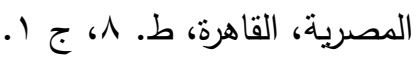

$$
\begin{aligned}
& \text { عبد الستار، محمد (ع ا •rام)، المسجد النبوي }
\end{aligned}
$$

[Y]

$[\Upsilon]$
وجـود الفناء، وقد تبين ذلك في معالجـة الفنـاء في بعض النماذج المعاصرة.

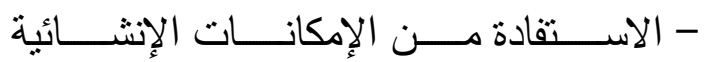
والتكنولوجية المعاصرة في عمل حلول غير تقليدية من حيث تطويعها في مرونـة موضـع الفناء وإيجاد علاقة حوارية إبداعية مسع فراغ المسجد ليحقق علاقة فراغية مناسبة وهادفة مجتمعياً وبيئياً. وتطوير مفهومه وتحرره من القيود المكانية إلى الانطلاقة الفراغية، كدراسـة فراغ الفناء في القطاع، وبساعد ذلك في توفير المساجد ذات الأفنية في نماذج الأبنية المتعددة الطوابق، وخاصـة في المـدن المزدحمـة، كـذلك الاســتفادة مـن تكنولوجيــا الصوتيات والإضـاءة، في معالجة فراغ الفناء والمسـد معا، لتحقيق التكامل في الأدوار الاجتماعية والوظيفية والبيئية. - معالجـة أفنيـة المسـاجد التي لا يتـوفر لهـا فـراغ طبيعـي كالمسـاجد المحاطـة بكتـل وفراغـات مغلقـة، بعمـل فراغــات افتراضـبية بمعالجـة حـوائط وأرضـية وسـقف الفـراغ الفرضـي للفنـاء بمعالجـات تكنولوجية معاصرة تتقل المستعمل بيئيا وبيولوجيا بل ومعنويـا بــفس مـا يثـعر بـهـ في الفنـاء الطبيعسي وتطويــع نكنولوجيـا الواقـع الافتراضـي ( Virtual reality )، والتي تطورت كثيرا في الآونة الأخيرة.

$$
\text { المراجع }
$$

الزركثي، محمد بن عبد الله (ت. ؛ \9)، إعالم

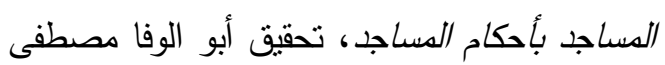

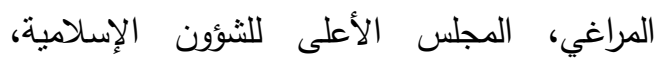


الدراسية الرابعة لمنظمة العواصم الإسلامية، جدة.

زغلول، سعد (919 (م))، الععاة والفنون في دولة

$$
\text { الإسلام، منشأة المعارف، الإسكندرية. }
$$

العقيلي، ميسون محي هلال (ب.r.م)، أثر

المسجد الجامع على المشهد الحضري للمدينة، منية

رسالة دكتوراه، المعهد العالي للتخطيط الحضري

$$
\text { والإقليمي، جامعة بغداد، العراق. }
$$

Uzunoglu, S. Sema and Uzunoglu, Kozan (2011), The application of formal perception of gestalt in architectural education, Procedia - Social and Behavioral Sciences, 28: 993 - 1003.

دراسات تستعرض دور فناء المسجد في توفير

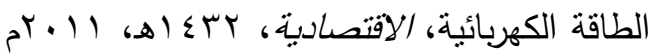

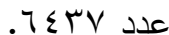

محمد حسن، زكي (1919)، فنون الإسلام، دار

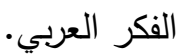

محمود شافعي، فريد (•VV (م)، العدارة العربية في مصر الإسالاية في عصر الولاة، الهيئة المصرية العامة للتأليف والنشر ، القاهرة.

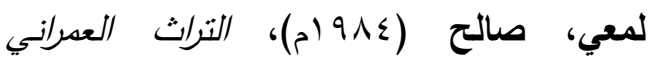
الإسلامي في مصر، دار النهضة العربية،

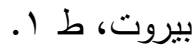

سلمان، عيسى وآخرون (بی19)، العمارات العربية الإسلامية في العرلق، ج ال، تخطبط مدن ومساجد، دار الرشيد للنشر، العراق. أحمد، حمدي صادق (7^ا9 (م)، دراسة تحليلبة لتطور تصديم المسجد، رسالة ماجيستير، كلية الهندسة والتكنولوجيا، جامعة حلوان. آصلانابا، أوقطاي (9^v) (ام)، فنون الترك

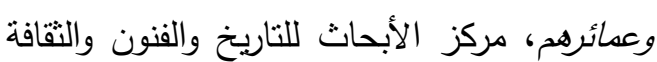

وبيوت أمهات المؤمنين، دراسة آثارية معدارية، وزارة الأوقاف والثئون الإسلامية، قطاع الثئون

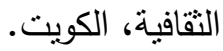
الجنابي، كاظم (ع ا • rم)، تخطبط مدينة الكوفة، حلبة الكوفة، عن المصادر التاريخية والأثرية "خاصة في العصر الأموي"، دورية سنوية محكمة

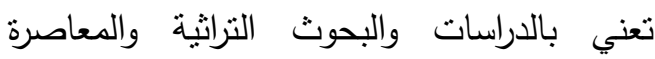
المتخصصة، أمانة مسجد الكوفة، العدد الرابع وليع رمضان 0بإ ا هـ. محمود شاقعي، فريد (ب191ام)، العماة العربية الإسلامية ماضبيها وحاضرها ومستقبلها ، العمارة العربية الإسلامية في عصورها المبكرة، الطبعة الاولى، جامعة الملك سعود، المملكة العربية السعودية.

Architecture as Symbol and Self-Identity (1979), Proceedings of Seminar Four in the series Architectural Transformations in the Islamic World, Held in Fez, Morocco.Britain: Academy Editions, 1996.

Al Khalifa, Haifa Ebrahim (2017), The Friday Mosque of the Arabian Gulf: Defining Its Spatial and Formal Languages -1975-2010, A Thesis Submitted to Welsh School of Architecture, Cardiff University.

Al-Jameel, H., Ali, (2008), Spatial Configuration Characteristics of Religious Buildings A Comparative Study between Islamic Mosques, Egyptian and Iraqi Temples, International Forum on Islamic Architecture and Design: Ideals, Innovation and Sustainability- IFIAD, At University of Sharjah-Sharjah, UAE.

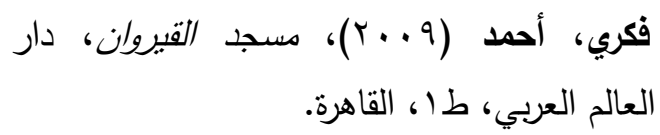

Yeomans, Richard (2006), The Art And Architecture Of Islamic Cairo, Garnet Publishing Limited, 8 Southern Court, South Street, Reading RG1 4QS, UK.

$$
\begin{aligned}
& \text { الرفاعي، خير الدين (ب99 (م)، نحو عمارة } \\
& \text { اصيلة ومعاصرة تستهد معطباتها من القيم } \\
& \text { الإسلامية وتقنيات العصر، سجل أبحاث الحلقة }
\end{aligned}
$$




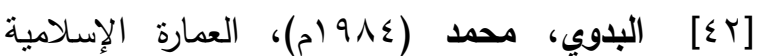

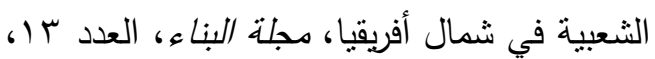
الرياض.

ليثابي، وليم ريتثارد (11 (1) ام)، العدارة والأسطورة

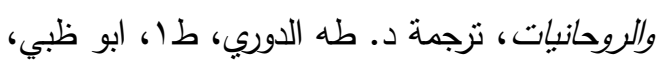
هيئة أبو ظبي للثقافة والتراث، كلمة.

عبد الباقي، إبراهيم، التراث الحضاري في العدينة العربية الدعاصرة، مركز الدراسات التخطيطية والمعمارية، القاهرة، 919 ام. صادق، أحمد صادق، 999 (م، التشكيل الفراغي وتأثنيره على علاقة المسجد بالبيئة العمرانية، ندوة

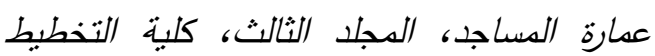
العدراني، جامعة الملك سعود، الرياض.

https://www.archiscene.net/location/turkey/istanbu 1-camlica-mosque-tuncer-cakmakli-architects/

Elham Hatami Varzaneh, Masoome Amini and Mohammad Reza Bemanian (2014). Impact of Hot and Arid Climate on Architecture (Case Study: Varzaneh Jame Mosque), 7th International Conference on Materials for Advanced Technologies, MRS Singapore - ICMAT Symposia Proceedings.

Yusupov P. and Bondarenko I. (2016) Innovative Approaches in the Design of Modern Islamic places of worship represented by Sancaklar Mosque in Istanbul. Kharkov State Academy of Design and Fine Arts.

Anselm, Akubue Jideofor (2012) Earth Shelters; A Review of Energy Conservation Properties in Earth Sheltered Housing, Anselm, licensee InTech, INTECh.

Tahbaz, Mansoureh, Djalilian, Sharbanoo and Fatemeh Mousavi (2014) Outdoor Microclimate Observation for Thermal Comfort in Harsh Desert Condition: A Study in Kashan Iran, School of Architecture, Shahid Beheshti University, Evin,, Civil Engineering and Architecture.

$$
\begin{aligned}
& \text { مقرن، خالا بن عبدالله، الحمدي، وناصر بن عبد } \\
& \text { الرحمن محمد (9991م)، أبراج التبريد الطبيعي } \\
& \text { وأثزها على الأداء الحراري للمساجد، ندوة عمارة }
\end{aligned}
$$

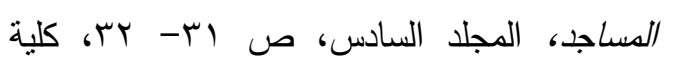

$$
\begin{aligned}
& \text { العمارة والتخطيط، جامعة الملك سعود، الرياض. }
\end{aligned}
$$

$$
\begin{aligned}
& \text { مصطفى، أحمد فريد (999 (م)، مشروع خادم } \\
& \text { الحرمين الثريفين لإعمار المساجد، ندوة عماة }
\end{aligned}
$$

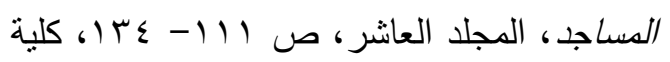

$$
\begin{aligned}
& \text { العمارة والتخطبط، جامعة الملك سعود، الرياض. }
\end{aligned}
$$

Google Earth, march, 2018.

Ahunb, AY Zeynep, (2012), Selimiye Mosque and its Social Complex, Ministry of Culture and Tourism General Directorate of Libraries and Publications.

Moustafa, Ahmed and Moustafa, Samaa (2013), Contemporary Mosque Architecture in Turkey, A Thesis Submitted to The Department of Arab and Islamic Civilization, The American University in Cairo.

Abouseif, Doris Behrens (1998), Islamic Architecture in Cairo, an Introduction, The American University in Cairo, Cairo, Egypt.

\section{$[r Y]$}

سراج الاين، إسماعيل (•(·r)، حسن فتحي،

المدسة والمسيبة، مكتبة الإنسكندية، طباعة قسم العمارة

$$
\text { بكلية العمارة والتخطيط بجامعة الدمام، يوم العمارة. }
$$

محمد ، أمجد علي محمد (11 • (Y)م)، أثز عزامل

البيئة الطبيعية والثقافية على الخصائص المعمارية والتخطيطية لمساجد السليمانية، مجلة المخطط

$$
\begin{aligned}
& \text { والتنمبة، العدد سب. } \\
& \text { عبد الحكيم، محمد صبحي (ب999 (م)، دراسات } \\
& \text { في جغرافية العالم الإسلامي، معهد الدراسات }
\end{aligned}
$$

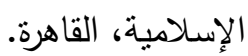
Watson, D., FAIA and Labs, K. (1983), Climatic
[esign McGraw-Hill Book Company, New York.

$$
\begin{aligned}
& \text { فتحي، حن (911 (م)، الطاقات الطبيعبة } \\
& \text { والعمارة التقليبية، المؤسسة العربية للاراسات }
\end{aligned}
$$

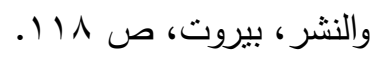

Muhaisen, S. and Gadi., M. B. (2006), Shading performance of polygonal courtyard forms. Building and Environment).

Wazeri, Y. H. (1997), The relation between solar radiation and building design in North Africa. M.Sc., thesis, Institute of African Research and Studies, Dep. Of Natural Resources, Cairo Univ., Cairo. 


\title{
Inner-court Mosque from Heritage to Contemporaneity
}

\section{Its Functional, Environmental, and Morphological Roles}

\author{
Wael Hussien Youssef
}

\author{
Department of Landscape Architecture, Faculty of Environmental Design, King Abdulaziz \\ University, Jeddah, Saudi Arabia \\ hywael@hotmail.com
}

\begin{abstract}
The court inside the mosque in its early architecture represented one of the most important and basic functional, social and environmental elements .In the beginning; mosque was formed out of two elements; covered area, and another open one that represents the "court", which in most of the mosques was surrounded by arcades from many sides. The mosques of the Prophet Mohammad (PBUH) and Qubaa contained a court in their original form. The court represented an extension of prayers area, especially in the occasions of congregational prayers. After that; the inner court mosque prevailed in many areas in Islamic world such as "Ahmad ibn Tulun" mosque in Egypt, "Cordoba" mosque in Andalusia, "Samarra" and "Great Mosque" in Qairawan, "Al-Azhar" mosque in Cairo, etc. The court had many functional, environmental, and morphological roles. The research reviews the history, origin, and concept of the formation of the inner-court mosque, and an analysis of different historical patterns of the court in heritage mosques. Also, it reviews the factors that influence the court formation, and the relation between the court and spaces inside the mosque, and outside it as well, and also clarifies the morphological vocabulary of the court architecture. The research also reviews the contemporary developments that affected the court and led to its disappearance. Finally, the research ends with suggested approaches in order to revitalize the court in a contemporary and unconventional way.
\end{abstract}

Keyword: Mosque, Court, Arcade, Courtyard (Sahn, Entrance (Majaz). 